\title{
Phaselis Antik Kenti Florası I
}

\section{Flora of the Ancient City of Phaselis I}

\author{
R. Süleyman GÖKTÜRK
}

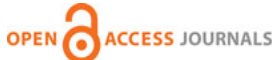

PHASELIS: Disiplinlerarası Akdeniz Araştırmaları Dergisi'nde bulunan içeriklerin tümü kullanıcılara açık, serbestçe/ücretsiz "açık erişimli" bir dergidir. Kullanıcılar, yayıncıdan ve yazar(lar)dan izin almaksızın, dergideki makaleleri tam metin olarak okuyabilir, indirebilir, dağıtabilir, makalelerin çıktısını alabilir ve kaynak göstererek makalelere bağlantı verebilir.

PHASELIS: Disiplinlerarası Akdeniz Araştırmaları Dergisi uluslararası hakemli elektronik (online) bir dergi olup değerlendirme süreci biten makaleler derginin web sitesinde (journal.phaselis.org) yıl boyunca ilgili sayının içinde (Volume I: Ocak-Aralık 2015) yayımlanır. Aralık ayı sonunda ilgili yıla ait sayı tamamlanır.

Dergide yayımlanan eserlerin sorumluluğu yazarlarına aittir.

Makale Künyesi $\quad$ R. S. Göktürk, "Phaselis Antik Kenti Florası I". Phaselis I (2015) 81-131. DOI: 10.18367/Pha.15005 Kabul Tarihi: 02.03.2015 | Online Yayın Tarihi: 17.06.2015

Editörya Phaselis Research Project www.phaselis.org 


\title{
Phaselis Antik Kenti Florası I
}

\section{Flora of the Ancient City of Phaselis I}

\author{
R. Süleyman GÖKTÜRK*
}

Öz: Bu çalışmada Phaselis antik kentinde yetişen bitkiler yer almaktadır. 2012 yılında başlayan ve beş yıl sürecek olan projenin ilk iki yılında tespit edilen bitkiler ve genel özellikleri bu makalede verilmiştir. 2012 ve 2013 yilında alandan toplanan bitkilerin teşhis edilmesiyle 57 familya'ya ait 191 cins ve toplam 233 takson tespit edilmiştir. Bu 233 taksonun 181 tanesi tür, 35 tanesi alttür ve 17 tanesi ise, varyete düzeyindedir. Tespit edilen 233 taksonun 30 tanesi endemiktir. Bu 30 endemik taksonun 10 tanesi OlimposBeydağları Milli Parkı endemiği, 10 tanesi Antalya endemiği ve 10 tanesi de Türkiye endemiğidir. 233 taksonun 136 tanesi Akdeniz Fitocoğrafik Bölgesi elementi, 3 tanesi Avrupa-Sibirya Fitocoğrafik Bölgesi elementi, 2 tanesi İran-Turan Fitocoğrafik Bölgesi elementi ve 92 tanesi ise Çok Bölgeli veya Fitocoğrafik Bölgesi bilinmeyendir. Bu dönemde teşhis edilen 233 taksonun 3 tanesi Pteridophyta (Eğreltiler) şubesine, 230 takson ise, Magnoliophyta (Tohumlu bitkiler) şubesine aittir. Pinophytina (Açık tohumlular) alt şubesinde 6, Magnoliophytina (Kapalı tohumlular) alt şubesinde ise 224 takson yer almaktadır. Magnoliophytina (Kapalı tohumlular) alt şubesinde yer alan 224 taksonun 184 tanesi Magnoliopsida (Dikotiller) sınıfına, 40 tanesi ise, Liliopsida (Monokotiller) sınıfına aittir.

Anahtar sözcükler: Phaselis · Antalya · Bitkiler · Endemik · Pteridophyta · Magnoliophyta · Magnoliopsida · Pinophytina $\cdot$ Liliopsida

Abstract: In this study the flora of the ancient city of Phaselis is introduced. The project over the course of 5 years that began in 2012, surveyed the plants found within the first two years of this project at Phaselis, and their main features are presented in this paper. 191 species of 57 families and a total of 233 taxa were determined through identifying the plants gathered from the field in the years 2012 and 2013. Of these 233 taxa, 181 are species, 35 are subspecies and 17 are in the variety level. Of the 233 taxa determined, 30 are endemic. Of the 30 endemic taxa, 10 are endemic to the Olimpos-Beydağları National Park, 10 to Antalya province and 10 to Turkey. Of the 233 taxa, 136 are elements of the Mediterranean Phytogeographical Region, 3 are of the European-Siberian Phytogeographical Region, 2 are of the IranianTuran Phytogeographical Region and 92 are of Multi-Region or of an unknown region. Of the 233 taxa determined during this research period, 3 belong to phylum Pteridophyta (Fern) and 230 to phylum Magnoliophyta (Flowering plants). There are 6 taxa in the subphylum Pinophytina (Gymnosperms) and 224 in the subphylum Magnoliophytina (Angiosperms). Of the 224 taxa in the subphylum Magnoliophytina (Angiosperms), 184 belong to the class Magnoliopsida (Dicotyles) and 40 to the class Liliopsida (Monocotyles).

Keywords: Phaselis - Antalya - Flora - Endemic - Pteridophyta · Magnoliophyta - Magnoliopsida . Pinophytina $\cdot$ Liliopsida

\footnotetext{
* Prof. Dr., Akdeniz Üniversitesi, Fen Fakültesi, Biyoloji Bölümü, Antalya. gokturk@akdeniz.edu.tr
} 
Giriş

Ülkemiz, floristik açıdan oldukça zengin ve ilginç bir yapıya sahiptir. Ülkemizin, flora açısından sahip olduğu bu zenginlik ve ilginçliği, içerdiği endemik ve nadir türlerin sayılarının çokluğu ile açıklamak mümkündür. Zira ülkemizde yetişen toplam bitki türü sayısı, hemen hemen Avrupa kıtasındaki toplam tür sayısına yakındır. Bu zenginliğin başlıca sebepleri şu şekilde belirtilebilir: iklim farklılıkları, topografik çeşitlilikler, jeolojik ve jeomorfolojik çeşitlilikler, deniz, göl, akarsu gibi değişik su ortamı çeşitlilikleri, 0-5000 m’ler arasında değişen yükseklik farklııkları, üç değişik bitki coğrafyası bölgesinin birleştiği bir yerde oluşu, birçok cinsin gen merkezinin Anadolu olması, Anadolu'da tür endemizminin yüksek olması ve birçok kültür bitkisinin anaç türlerinin Anadolu ve çevresinde bulunması ${ }^{1}$.

Türkiye'nin en önemli turizm merkezlerinden birisi olan Antalya, deniz, güneş ve tarihi eserler yanında floristik açıdan da ülkemizin en zengin illerinin başında gelmektedir. Bunun en güzel örneği Antalya'da yetişen endemik bitki türlerinin sayısı ile açıklamak mümkündür. Antalya'da yetişen endemik bitki tür sayısı 690 civarındadır². Bu 690 endemik türün 245 tanesi ise Antalya endemiğidir. Yani Antalya il sınırlarının dışında yetişmezler. Tüm bu sayılar endemik bitkiler açısından Antalya'nın Türkiye'de birinci sırada yer almasını sağlamaktadır. Antalya il sınırları

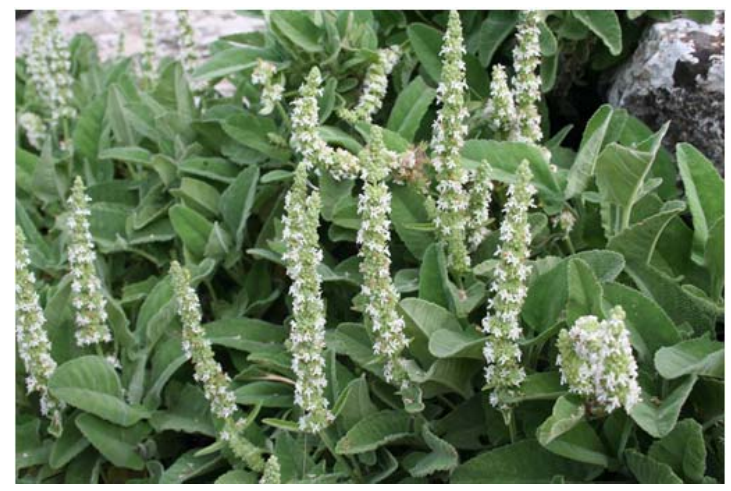

Fig. 1. Dorystoechas hastata içinde 4 tane Milli Park yer almaktadır. Bunlar, Altınbeşik Mağarası Milli Parkı (ibradı), Köprülü Kanyon Milli Parkı (Manavgat), Termessos Milli Parkı (Düzlerçamı) ve Olimpos-Beydağları Milli Parkı (Kemer)'dır. Olimpos-Beydağları Milli Parkı, diğer milli parklardan farklı olarak deniz ve ormanın iç içe bulunduğu bir milli parktır. Özellikle dağların denizin yakınlarından itibaren 2000 m’lere kadar yükselmeleri bu alanı bitkiler açısından özel korunaklı bir alan haline getirmiştir. Bu dağlar buzul devrinin soğuk ve öldürücü etkisinden kaçan bazı bitkiler için korunma alanı oluşturmuşlardır (Fig. 1).

Phaselis antik kenti, yukarıda bahsettiğimiz 4 milli parktan Olimpos-Beydağları Milli Parkı sınırları içinde yer almaktadır. Phaselis antik kenti denizi, kumsalı, tarihi eserleri ve biyoçeşitliliği ile birlikte zenginlik oluşturmaktadır. Olimpos-Beydağları Milli Parkı'nda yapılan floristik çalışma sonunda alandan 823 takson tespit edilmiştir ${ }^{4}$. Değişik araştırmacılar ve tarafımdan değişik projeler kapsamında yapılan arazi çalışmaları sonucunda ilave edilen taksonlarla bu sayının yaklaşık 1000 civarında olduğu tespit edilmiştir. Son yıllarda milli park sınırları içinden toplanarak bilim dünyasına tanıtılan yeni bitki taksonları da bulunmaktadır. Bunlara örnek olarak Trigonella coerulescens (M.Bieb.) Halácsy subsp. kemerensis Göktürk (kum çemenotu) ${ }^{5}$ (Fig. 2), Glycyrrhiza flavescens Boiss. subsp. antalyensis Sümbül, Ö. Tufan, O. D. Düşen \& Göktürk (Antalya meyanı) ${ }^{6}$

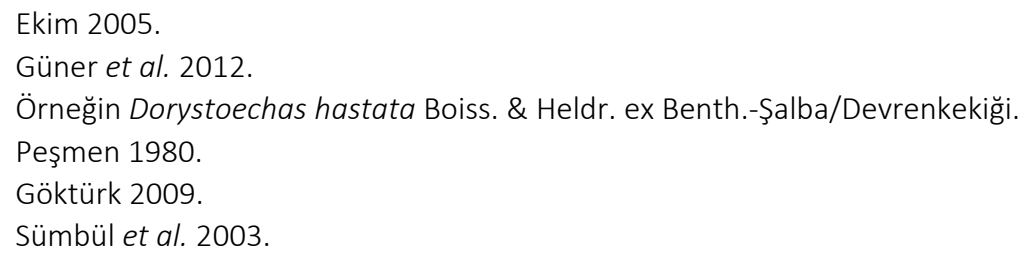




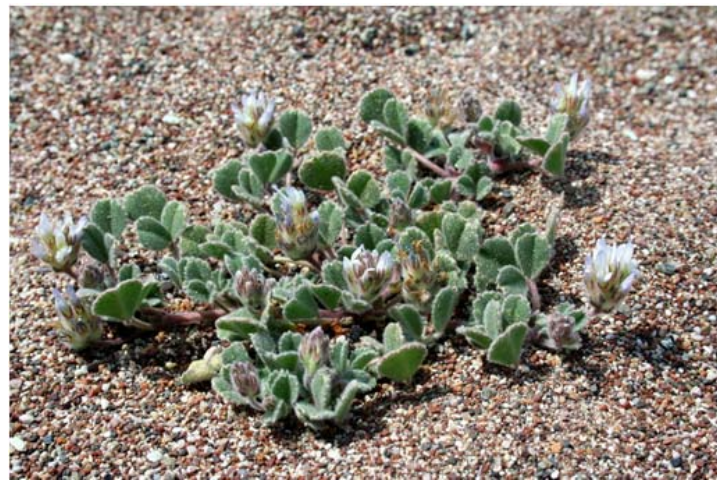

Fig. 2. Trigonella coerulescens subsp. kemerensis

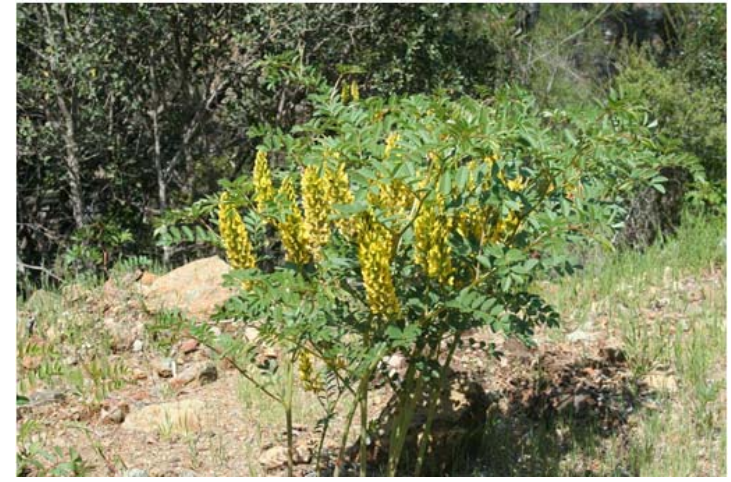

Fig. 3. Glycyrhiza flavescens subsp. antalyensis

(Fig. 3) ve Teucrium ekimii H. Duman (erkurtaran) ${ }^{7}$ verilebilir.

\section{Materyal ve Metot}

Çalışma materyalini, araştırma alanından 2012 ve 2013 yılında toplanan ve 2014-2016 yılları arasında toplanacak olan bitki örnekleri oluşturacaktır. Bu kapsamda 2012 ve 2013 yılında gözlenen ve adlandırılan bitkiler bu makalede listelenmiştir. 2013 yılında vejetasyon peryoduna bağlı olarak belirli aralıklarla arazi çalışması gerçekleştirilmiştir. Arazi çalışması esnasında bitki örnekleri mümkün olduğu kadar toplanmamaya çalışılmış, ancak arazide teşhisi yapılamayan örnekler alınmıştır. Bu örnekler toplanırken, teşhiste zorluk yaşanmaması için her familya'ya ait notlar tutulmuş ve mutlaka alınması gereken bitki kısımları alınmaya çalışılmıştır. Değişik lokalitelerden ve habitatlardan toplanan örnekler zarar görmemesi ve lokalitelerin karışmaması için ayrı ayrı poşetlere konulmuştur. Ayrıca arazide bitkilerin resimleri de çekilmiştir. Gözlemi yapılan ve toplanan örnekler ilk önce familya düzeyinde, daha sonra ise cins, tür varsa alt tür ve varyete düzeyinde teşhisleri yapılmıştır. Teşhis esnasında makroskobik ve mikroskobik özelliklerinden yararlanılmıştır. Bitkilerin teşhisinde, başta Türkiye Florası ${ }^{8}$ olmak üzere Avrupa Florası'ndan ${ }^{9}$, İalya Florası'ndan ${ }^{10}$, çalışma alanına yakın diğer floristik çalışmalardan ${ }^{11}$, bitkilerin resim ve şekillerinin yer aldığı renkli el kitaplarından ${ }^{12}$ yararlanılmış olup ileride toplanacak bitkilerin de teşhislerinde de yararlanılacaktır. Teşhisi yapılan örnekler teşhisin bitiminde, bitki türlerini bilimsel olarak tanıtan etiketleriyle birlikte 35×50 cm boyutlarındaki kartonlara yapıştııımış, Akdeniz Üniversitesi Herbaryumunda (AKDU) muhafaza edilmektedir. İlerki yıllarda da toplanacak örnekler de bu şekilde toplanarak benzer işlemlerden geçirileceklerdir.

Bulgular kısmında bulunan familyalar ve türler harf sırasına göre verilmiştir. Bitki listesi verilirken sırasıyla familya'nın Latince ve Türkçe adı, tür adı, yazarı, varsa alt tür veya varyete adı, yazarı, varsa endemiklik durumu verilmiştir. Daha sonra her bitkiye ait açıklayıcı özellikleri verilmiştir. En son olarak ise bitkinin ait olduğu Fitocoğrafik bölge verilmiştir. Bitki listesi hazırlanırken

\footnotetext{
Duman 1998.

Davis, 1965-1985; Davis et al. 1988; Güner et al. 2000.

Tutin et al. 1964-1980.

10 Pignatti 1982.

11 Peşmen - Güner 1976; Peşmen 1980; Ayaşlıgil 1987; Göktürk - Sümbül 1997; Duman et al. 2000; Dinç Sümbül 2001; Mutlu - Erik 2003; Alçıtepe - Sümbül 2003; Deniz - Sümbül 2004; Çinbilgel 2005.

12 Sümbül et al. 1998a; Sümbül et al. 1998b; Dingil 2002; Mataracı 2004; Sümbül et al. 2005; Tekin 2005; Sümbül et al. 2006.
} 
2012 yılında yayınlanan “Türkiye Bitkileri Listesi”nden yararlanılmıştır ${ }^{13}$. Bitkilerin Türkçe isimleri kısmında ise yine "Türkiye Bitkileri Listesi"nde yer alan isimler kullanılmıştır ${ }^{14}$. Bulgular kısmında kullanılan kısaltmalar ise şunlardır: Akd. El.: Akdeniz Elementi; Ir.-Tur. El.: Iran-Turan Elementi; Avr.-Sib. El.: Avrupa-Sibirya Elementi; ÇBFCB: Çok Bölgeli veya Fitocoğrafik Bölgesi Bilinmeyen.

Bulgular

Şube: Pteridophyta (Eğreltiler)

Familya: Aspleniaceae (Saçakotugiller)

Asplenium ceterach L. (dalakotu)

Dik ve kısa rizomlu bitkiler. Yapraksı gövde kümeli, 8-20 cm boyunda, pinnatifid parçalı parçalar ise dikdörtgenimsi, tabanda geniş. Spor keseleri şeritsi. Nisan ayında sporları olgunlaşan bu tür, kuru duvarlar üzerinde, kireçtaşlı ve metamorfik kayalıklarda yetişir. ÇBFCB.

Familya: Equisetaceae (Atkuyruğugiller)

Equisetum telmateia Ehrh. (deredoruk)

Verimli ve verimsiz gövdeye sahip bitkiler. Verimsiz gövdeler 200 cm'ye kadar boylanır, dik ve yeşilimsi beyaz renkli. Dalcıklar çok sayıda, 4 yivli. Verimli gövdeler $40 \mathrm{~cm}$, soluk kahve renkli, çok sayıda. Yapraklar küçük. Bu tür, yetişme ortamı olarak deniz seviyesinden 1200 m’ye kadar yüksekliklerdeki bataklık kenarlarını ve nemli yerleri tercih eder. ÇBFCB.

Familya: Pteridaceae (Baldırıkaragiller)

Adiantum capillus-veneris L. (baldırıkara)

Sürünücü rizomlu bitkiler. Yapraksı gövde $10-40 \mathrm{~cm}$ boyunda, 2 pinnat parçalı, uç segmentleri ince. Spor keseleri yaprak kenarlarının loplarında kıvrılmıs durumda. Sporları ocak-ekim aylarında olgunlaşan bu eğrelti, 800 m’ye kadar olan yüksekliklerdeki kireç taşlı kayalık yarıklarında ve besince zengin topraklarda yetişir. ÇBFCB.

Şube: Magnoliophyta (Tohumlu Bitkiler)

Altşube: Pinophytina (Açık Tohumlular)

Altsınıf: Gnetidae

Familya: Ephedraceae

Ephedra foeminea Forssk. (borotu)

Sürünücü gövdeli, zayıf dallı, dallar bükük veya tırmanıcı bitkiler. Yapraklar çoğunlukla dökülücü veya pul şeklinde indirgenmiş. Erkek çiçekler yarı küremsi veya dikdörtgenimsi kozalağa benzeyen şekillerde, dişi çiçekler karşııklı dizilmiş veya nodyumlardan çıkan 3-4 adet kozalağa benzeyen yapının ekseni boyunca bulunur. Karpel ve periyant yaprakları etlenerek meyveye benzeyen yalancı ve etli bir meyve oluşturur. ÇBFCB.

Altsınıf: Pinidae

Familya: Cupressaceae (Servigiller)

Cupressus sempervirens L. (servi)

30 m'ye kadar boylanabilen tek evcikli ağaçlar. Yapraklar pulsu, basık. Erkek kozalaklar dal uçlarında, silindir şeklinde, en fazla $7 \mathrm{~mm}$ boyunda. Dişi kozalaklar 2-3 x 2-2.5 cm, önce yeşil, olgunlaşınca kahverengimsi-gri renkli. Meyve odunsu kozalak, küresel veya eliptik. Tohumlar re-

13 Güner et al. 2012.

14 Güner et al. 2012. 
çinesiz ve kanatlı. Akdeniz Bölgesi'nin tipik bir ağacı olan serviler, 300-1200 m'ler arasındaki yamaçlarda ve kireçtaşlı kayalıklarda yetişir. Akd. El.

\section{Juniperus oxycedrus L. subsp. oxycedrus var. oxycedrus (katran ardıcı)}

4-6 m’ye kadar boylanabilen iki evcikli ağaçlar veya çalılar. Yapraklar mızraksı, seyrek, 6-25 mm boyunda, uçları sivri ve batıcı, üst yüzeyi orta damar ile ayrılmış beyaz iki stoma bantlı. Üzümsü kozalaklar, küre şeklinde, önceleri mavi-puslu, daha sonra koyu kırmızı veya mor ya da parlak kahve renkli, 6-8 mm çapında. Her kozalak 2-3 adet tohumlu. Bu alt tür, deniz seviyesinden 1300 (-1800) m’ye kadar olan yüksekliklerdeki çam ormanlarını, meşe çalılıklarını ve makilikleri yaşama ortamı olarak tercih eder. ÇBFCB.

\section{Familya: Pinaceae (Çamgiller)}

Cedrus libani A. Rich var. libani (katran ağacı, Toros sediri) (Fig. 4)

Uzun boylu, herdem yeşil ağaçlar. Dallar yere paralel pozisyonda. Yapraklar 1-4 cm boyunda, iğnemsi, kalıcl, uzun sürgünlerde dağınık, kısa sürgünlerde ise bir daire etrafında dizili. Erkek kozalaklar dik ve silindirik. Olgun dişi kozalaklar dik, yumurtamsı, 6-9 cm boyunda. Kozalak pulları odunsu, olgun halde düşücü. 1000-2000 m’ler arasında yetişen bu tür baskın bir ağaçtır veya diğer ağaçlarla karışık yetişir. Akd. El.

\section{Pinus brutia Ten. var. brutia (kızılçam)}

25 m'ye kadar boylanabilen herdem yeşil ağaçlar. Yapraklar kısa sürgünlerden çift halde çıkar, 18 cm'ye kadar boylanır ve açık yeşil renkli. Tomurcuklar reçinesiz. Kozalaklar uzun, kahve renkli, sapsız veya çok kısa saplı. Tohumlar kanatlı. 1200 m yüksekliklere kadar yayılı̧ gösteren bu ağaç ülkemizde kuzey, güney ve batı Anadolu'da yayılış gösterir. Akd. El.

\section{Pinus nigra Arn. subsp. pallasiana (Lamb.) Holmboe} var. pallasiana (karaçam)

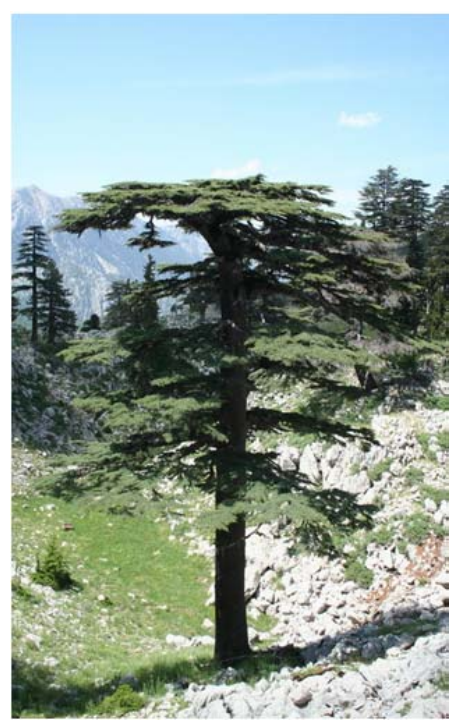

Fig. 4. Cedrus libani var. libani

Herdem yeşil ve 30 m'ye kadar boylanabilen ağaçlar. Yapraklar kısa sürgünlerden çift halde çıkar, 7-18 cm boyunda ve koyu yeşil renkli. Tomurcuklar reçineli. Kozaklar yumurtamsı, dik veya eğik tırmanışı. Tohumlar kanatlı. Bu alt tür, Güney Anadolu'da 1000 m’nin üzerindeki yüksekliklerde, kızılçam'ın yerini alır. Orta Anadolu'da ise 3 lokaliteden bilinmektedir. ÇBFCB.

Altşube: Magnoliophytina (Kapalı Tohumlular)

Sınıf: Magnoliopsida (Dikotiller)

Familya: Anacardiaceae (Menengiçgiller)

Cotinus coggyria Scop. (peruka çalısı, duman ağacı)

5 m'ye kadar boylanabilen yaprak döken çalılar. Yapraklar saplı, ters yumurtamsı, geniş eliptik veya dairesel. Sepaller yaklaşık $1.5 \mathrm{~cm}$ boyunda. Petaller beyazımsı-yeşil renkli. Drupa meyve oblik ters yumurtamsı. Nisan-haziran ayında çiçeklenen bu tür, yetişme ortamı olarak deniz seviyesinden 1300 m'ye kadar olan yüksekliklerdeki makilikleri, çalııkları ve ormanlıkları tercih eder. ÇBFCB.

\section{Pistacia lentiscus L. (sakız ağacı)}

1-3(-5) m boyunda, herdem yeşil ağaçlar veya çalılar. Yapraklar paripinnat, derimsi; yaprakçıklar dikdörtgenimsi veya dikdörtgenimsi-mızraksı. Çiçekler tek eşeyli. Eriksi meyve 1 tohumlu, oblik. 
Deniz seviyesinden 200 m'ye kadar olan yüksekliklerdeki makilikleri yetişme ortamı olarak tercih eden bu tür, mart ve nisan aylarında çiçeklenir. Akd. El.

\section{Pistacia palaestina Boiss. (çöğre)}

2-3 m boyunda çalılar veya 6 m’ye kadar boylanabilen ağaçlar. Yapraklar dökülücü, imparipinnat veya paripinnat parçalı; yaprakçıklar yumurtamsı-dikdörtgenimsi veya dikdörtgenimsi-mızraksı. Çiçekler tek eşeyli. Drupa meyve küresel veya geniş ters yumurtamsı. Bu alt tür, ülkemiz dışında Kıbrıs, Lübnan ve Filistin'de de yayılış göstermekte olup, mart-mayıs aylarında çiçeklenir. Yetişme ortamı olarak ise 50-1500 m'ye kadar olan yüksekliklerdeki kayalık yamaçları, makilikleri, yalancı makilikleri ve kızılçam ormanlarını tercih eder. Akd. El.

\section{Rhus coriaria L. (sumak)}

3 m’ye kadar boylanabilen çalılar. Yapraklar pinnat parçalı; yaprakçıklar geniş mızraksıdan eliptiğe kadar değişen şekillerde, dişli kenarlı. Eriksi meyve küresel, kırmızımsı, tüylü. Haziran-temmuz aylarında çiçeklenen bu tür, yetişme ortamı olarak ise 600-1900 m’ler arasındaki çalııkları ve ormanlıkları tercih eder. ÇBFCB.

\section{Familya: Apiaceae (Maydanozgiller)}

\section{Ammi visnaga (L.) Lam. (hıltan)}

Dik ve sağlam yapılı, 15-100 cm boyunda, iki veya çok yıllık otsu bitkiler. Yapraklar 2-pinnat parçalı, üçgenimsi-yumurtamsı; loplar şeritsi veya şeritsi-ipliksi. Şemsiyemsi çiçek durumu uzun saplı, saplar 30-150 adet. Petaller beyaz renkli. Merikarp meyveler dikdörtgenimsi. Yetişme ortamı olarak deniz seviyesinden 700 m'ye kadar olan yüksekliklerdeki tarlaları, yol kenarlarını ve düzlükleri tercih eden bu tür mayıs-ağustos aylarında çiçeklenir. Akd. El.

\section{Bunium ferulaceum Sm. (incirop)}

Dallı, çıplak, dik gövdeli, 13-40 cm boyunda, çok yıllık otsu bitkiler. Taban yaprakları genişçe üçgenimsi; segmentler şeritsi. Çiçekler beyaz renkli, her şemsiyede 11-17 tane. Meyveler dikdörtgenimsi-silindirik. Ülkemizin batı kesiminde yayılış gösteren bu tür, yetişme ortamı olarak deniz seviyesinden 1800 m'ye kadar olan yüksekliklerdeki karaçam ve kızılçam ormanlarını, mısır tarlalarını ve stebi tercih eder. Çiçeklenme zamanı ise mayıs ve haziran aylarıdır. Akd. El.

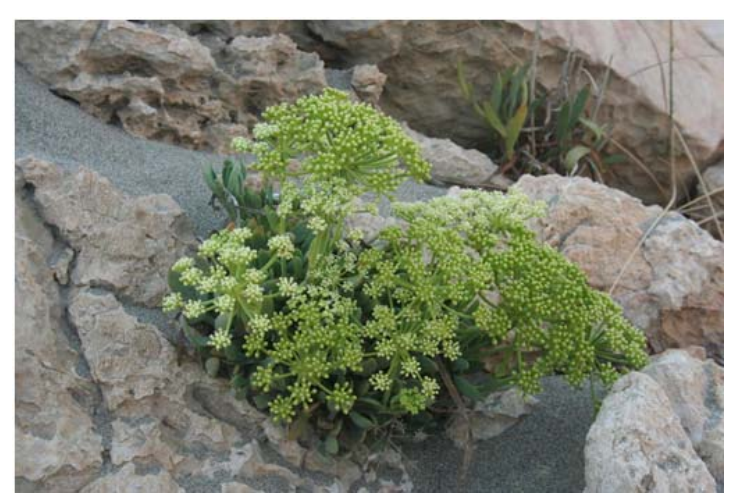

Fig. 5. Crithmum maritimum

\section{Crithmum maritimum L. (deniz teresi) (Fig. 5)}

Dallı, çıplak, 50 cm'ye kadar boylanabilen çok yıllık otsu bitkiler. Yapraklar etli; alt yapraklar üçgenimsi, 1-2 pinnat parçalı. Brakte ve brakteoller mevcut. Çiçekler sarımsı-yeşil renkli, her şemsiyede 10-20 tane. Meyve yumurtamsı-dikdörtgenimsi. Yetişme ortamı olarak ülkemizin sahil kenarlarındaki kayalıkları ve yamaçları tercih eden bu tür, temmuz-ekim aylarında çiçeklenir. ÇBFCB.

\section{Daucus guttatus Sibth. \& Sm. (benekli havuç)}

$40 \mathrm{~cm}$ 'ye kadar boylanabilen dallanmış, dik veya dik-eğik tırmanışlı tek yıllık otsu bitkiler. Yapraklar 2-pinnat parçalı; uç segmentleri dar kamamsı. Brakteler parçalı. Petaller beyaz renkli. Meyve 2-4 mm boyunda dikenli. Mayıs-temmuz aylarında çiçeklenen bu tür, deniz seviyesinden 800 m’ye 
kadar olan yüksekliklerdeki sahiller, yamaçları ve tarlaları yetişme ortamı olarak tercih eder. ÇBFCB.

\section{Eryngium glomeratum Lam. (top boğadikeni)}

30-60 cm boyunda, çok-gövdeli ve yoğun yapraklı çok yıllık bitkiler. Yapraklar 2-pinnatisekt parçalı; segmentler dikenli. Çiçek durumu dikdörtgenimsi. Brakte ve brakteol mevcut. Çiçekler mavimsi veya beyazımsı renkli. Meyve hemen hemen yumurtamsı. Temmuz- eylül aylarında çiçeklenen bu tür, yetişme ortamı olarak deniz seviyesinden 1600 m’ye kadar olan yüksekliklerdeki kayalık yerleri, friganayı, uçurumları ve tahrip edişmiş stebi tercih eder. ÇBFCB.

\section{Eryngium maritimum L. (kum boğadikeni) (Fig. 6)}

Sağlam yapılı çok yıllık otsu bitkiler. Gövde dallı ve $20-35 \mathrm{~cm}$ boyunda. Taban yaprakları kalın ve derimsi, yarı dairesel ve geniş üçgenimsi dikenli uçlu. Kapitula yumurtamsı, 10-25 mm çapında. Brakte ve brakteol mevcut. Çiçekler mavimsi veya beyazımsı renkli. Meyve hemen hemen yumurtamsı. Deniz kıyısındaki kumullarda yetişen bu tür, haziran-ağustos ayında çiçeklenir. ÇBFCB.

\section{Ferula tingitana L. (kadıteresi)}

2 m'ye kadar boylanabilen çok yıllık bitkiler.

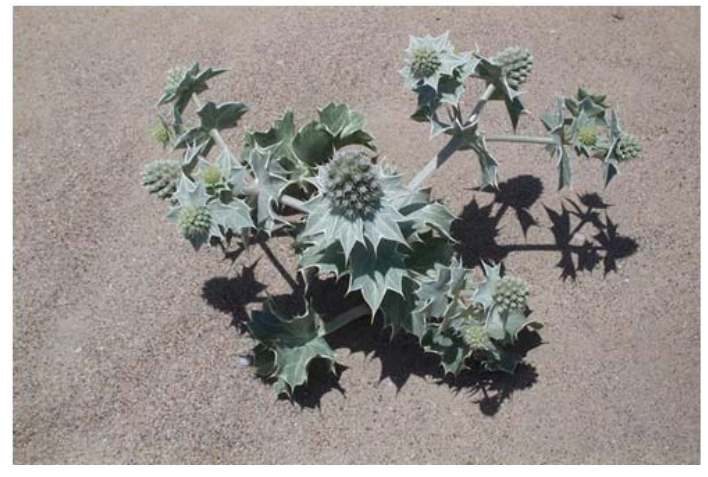

Fig. 6. Eryngium maritimum

Taban yaprakları 4 pinnat parçalı, 30-50 x 20-45 cm boyunda, uç segment yumurtamsı. Çiçekler her şemsiyede 12-25 adet, sarı renkli. Merikarplar eliptik-dikdörtgenimsi. Ülkemizde batı ve güneybatı Anadolu'da 100 m’ye kadar olan yüksekliklerdeki kayalık yamaçları ve boş alanları yetişme ortamı olarak seçen bu tür, nisan ve mayıs ayında çiçeklenir. Akd. El.

\section{Lagoecia cuminoides L. (pülüskün)}

Narin yapılı, 6-40 cm boyunda tek yıllık otsu bitkiler. Yapraklar dar dikdörtgenimsiden dar eliptiğe kadar değişen şekillerde; yaprakçıklar yumurtamsı, derin parçalı. Şemsiye küresel, 9-18 mm çapında. Petaller beyaz. Merikarp meyve yumurtamsı ve küçük beyaz tüylerle kaplı. Nisanhaziran aylarında çiçeklenen bu tür, yetişme ortamı olarak deniz seviyesinden 1100 m'ye kadar olan yüksekliklerdeki yol kenarlarını, kuru tarlaları, tepeleri, meşe ve badem çalııklarını tercih eder. Akd. El.

\section{Orlaya daucoides (L.) Greuter (dilkanatan)}

Eğik tırmanışlı-dik gövdeli, dallı 8-30 cm boyunda tek yıllık otsu bitkiler. Yapraklar 2(-3) pinnat parçalı. Dıştaki petaller 5-7 mm boyunda beyaz veya pembe renkli. Meyve dikenli gibi tüylü. Nisan-haziran aylarında çiçeklenen bu tür, deniz seviyesinden 1000 m’ye kadar olan yüksekliklerdeki ormanları, çalııkları, yamaçları ve tarlaları tercih eder. Akd. El.

\section{Familya: Apocynaceae (Zakkumgiller)}

Cionura erecta (L.) Griseb. (babrik)

8 m'ye kadar boylanabilen, çok gövdeli bitkiler. Yapraklar yumurtamsı veya genişçe yumurtamsı, üst kısımda parlak yeşil, alt kısımda unsu. Korolla beyaz renkli. Folikül meyve $8 \mathrm{~cm}$ 'ye kadar boylanır. Yetişme ortamı olarak deniz seviyesinden 1400 m’ye kadar olan yüksekliklerdeki kireç taşı kayalıkları, tarlalar, nehir yatakları, plajları ve nemli yerleri tercih eder. Çiçeklenme zamanı ise nisan-eylül aylarıdır. Akd. El. 
Nerium oleander L. (zakkum)

6 m'ye kadar boylanabilen çalılar. Yapraklar 3'lü halkasal dizilişli, dar eliptik-mızraksı. Kaliks 5-7 $\mathrm{mm}$ boyunda. Korolla pembe, kırmızı veya beyaz renkli. Folikül meyve 10-18 cm boyunda. Yetişme ortamı olarak 800 m'ye kadar olan yüksekliklerdeki ırmak kenarlarını ve kuru nehir yataklarını tercih eder. Çiçeklenme zamanı ise nisan-eylül aylarıdır. ÇBFCB.

Familya: Araliaceae (Sarmaşıkgiller)

\section{Hedera helix L. (Duvar sarmaşı̆̆ı)}

30 m’ye kadar boylanabilen, odunlu, tırmanıcı veya sürünücü çok yıllık bitkiler. Yapraklar basit, saplı, eliptikten elsi lopluya kadar değişen şekillerde. Petaller 3-5 mm boyunda, yeşilimsi. Üzümsü meyve sarı veya mavimsi-siyah. Ağaçlara tırmanan veya toprak üzerinde sürünücü olan bu tür, ağustos-eylül aylarında çiçeklenir. ÇBFCB.

\section{Familya: Aristolochiaceae (Lohusaotugiller)}

\section{Aristolochia lycica Davis \& M.S. Khan (kargakavuğu) (Antalya endemiği) (Fig. 7)}

10-40 cm boyunda, basit veya dallı, zikzaklı gövdeli çok yıllık otsu bitkiler. Yapraklar şeritsimızraksı veya dar üçgenimsi. Periyant dış kısımda koyu mor morumsu renkli; tüp $U$ şeklinde, dudaklar yumurtamsı-dikdörtgenimsi. Meyve kapsül. Antalya iline özgü olan bu tür, 800-1300 m’ler arasındaki tarlalarda ve kireçtaşı kayalıklarda yetişir. Çiçeklenme zamanı ise nisan ayıdır. Akd. El.

\section{Familya: Asteraceae (Papatyagiller)}

Anthemis ammophila Boiss.\& Heldr. (kum papatyası) (Antalya endemiği) (Fig. 8)

Kalkık uçlu veya dik duruşlu tek yıllık otlar. Yapraklar dikdörtgenimsi, 2-pinnatisekt parçalı. Dilsi çiçekler beyaz renkli, tüpsü çiçekler sarı renkli. Aken meyveler oluklu ve mor renkli. Antalya iline özgü olan bu papatya türü, nisan ve mayıs aylarında çiçeklenir. Yetişme ortamı olarak deniz kıyısındaki kumulları tercih eder. Akd. El.

\section{Asteriscus spinosus (L.) Sch.Bip. (dikenotu)}

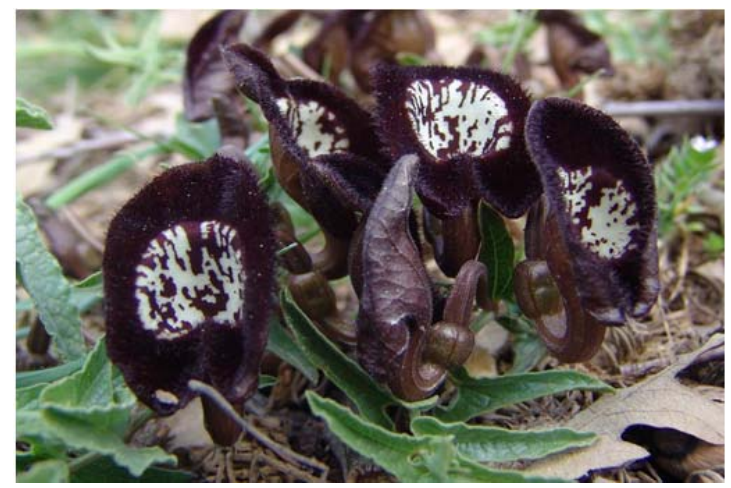

Fig. 7. Aristolochia lycica

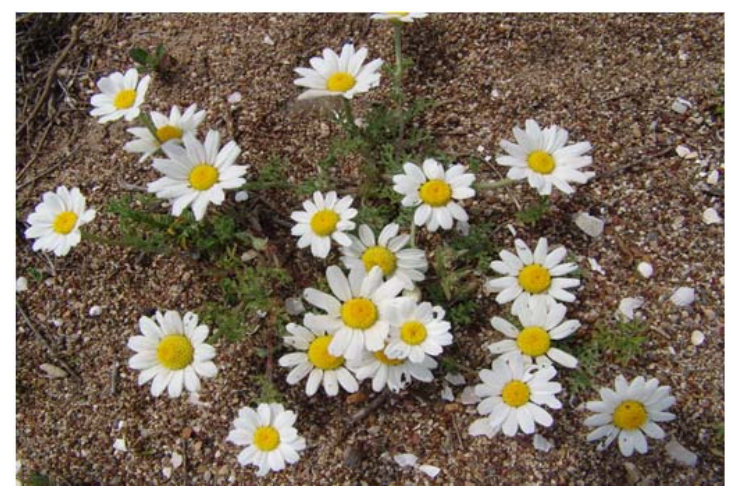

$60 \mathrm{~cm}$ 'ye kadar boylanabilen tek yıllık otlar.

Fig. 8. Anthemis ammophila

Yapraklar basit, dikdörtgenimsi veya ters mızraksı. Çiçekler sarı renkli. Aken meyve basık tüylü. Bu tür, yetişme ortamı olarak deniz seviyesinden başlayarak 250 m’ye kadar olan yüksekliklerdeki yol kenarlarını, kayalık yerleri ve kireç taşı kayalıklarını tercih eder. Nisan-ağustos aylarında çiçeklenir. Akd. El.

\section{Bellis annua L. (akbubeçlik)}

10 cm'ye kadar boylanabilen, dik veya kalkık uçlu tek yıllık otlar. Yapraklar kaşıksı. Dilsi çiçekler beyaz renkli, tüpsü çiçekler sarı renkli. Aken meyveler uç kısımda tüylü. Şubat-mayıs aylarında çi- 
çeklenen bu akbubeçlik, yetişme ortamı olarak deniz seviyesinden 300 m'ye kadar olan yüksekliklerdeki nemli yerleri tercih eder. Akd. El.

\section{Bellis perennis L. (koyungözü, çayır kasımpatı)}

Çok yıllık, çoğunlukla gövdesiz otlar. Yapraklar kaşık şeklinde. Dilsi çiçekler beyaz veya pembe, tüpsü çiçekler sarı renkli. Akenler ters yumurta biçimli ve seyrek tüylü. Yetişme ortamı olarak deniz seviyesinden 2000 m'ye kadar olan orman altındaki nemli yerleri tercih eden bu tür martağustos aylarında çiçeklenir. Avr.-Sib. El.

\section{Calendula arvensis L. (portakal nergisi)}

Dik veya yayılııı çok yıllık otlar. Gövde genellikle çok dallı, 15-25 cm boyunda. Yapraklar dikdörtgen veya ters yumurtamsı. Dilsi çiçekler sarı veya turuncu, tüpsü çiçekler sarı, kahverengi veya menekşe-mor renkli. Meyve aken. Çok geniş bir yayılış alanına sahip olan bu tür, yetişme ortamı olarak deniz seviyesinden 2000 m'ye kadar olan kültür tarlaları, yol kenarı, kayalık yerleri tercih etmektedir. ÇBFCB.

\section{Carlina corymbosa L. (kırkbaş dikeni)}

Tüylü çok yıllık otlar. Gövde dik, yükselici, basit veya dallı, 22-60 cm boyunda. Yapraklar mızraksı, dikdörtgenimsi-mızraksı. Dıştaki fillarilerin uçları dikenli. içteki fillariler parlak sarı renkli. Çiçekler sarı renkli. Aken meyve basık tüylü. Bilim dünyasına İtalya'dan tanıtılan bu tür, ülkemiz dışında güney Avrupa ve batı Suriye'de yayılış göstermektedir. Yetişme ortamı olarak 10-1450 m’ler arasındaki kızılçam ormanlarını, kuru tepeleri ve tarlaları tercih eder. Bu bitkinin çiçeklenme zamanı ise temmuz-eylül aylarıdır. Akd. El.

\section{Carthamus dentatus (Forssk.) Vahl (kınadikeni)}

100 cm'ye kadar boylanabilen çok yıllık otlar. Yapraklar yumurtamsı-keskin sivri uçlu, gövdeyi sarıcı, uçları dikenli. Çiçekler mor-pembe renkli. Aken meyve tüysüz. Bu tür, yetişme ortamı olarak deniz seviyesinden 1250 m'ye kadar olan yüksekliklerdeki, stebi, kuru kalkerli toprakları ve nehir yataklarını tercih eder ve temmuz-ağustos aylarında çiçeklenir. ÇBFCB.

Centaurea aegialophila Boiss. \& Heldr. ex Boiss. (kum deligözü) (Fig. 9)

Basit veya birkaç dallı çok yıllık otlar. Yapraklar tüylü, lirat parçalı. Apendaj dar ve zarımsı. Çiçekler pembe (içtekiler bazen beyaz) renkli. Aken meyve yoğun tüylü. Bu kum deligözü sahil kenarlarındaki kumullarda yetişir ve nisan-mayıs aylarında çiçeklenir. Bu tür, ülkemiz dışında Girit ve Kıbrıs'ta yayılış göstermektedir. Akd. El.

\section{Centaurea dichroa Boiss. \& Heldr. (alabaş)} (Türkiye endemiği)

Tabanda odunsu, çok yıllık bitkiler. Yapraklar beyaz-keçemsi tüylü, pinnat veya lirat parçalı. Çiçek-

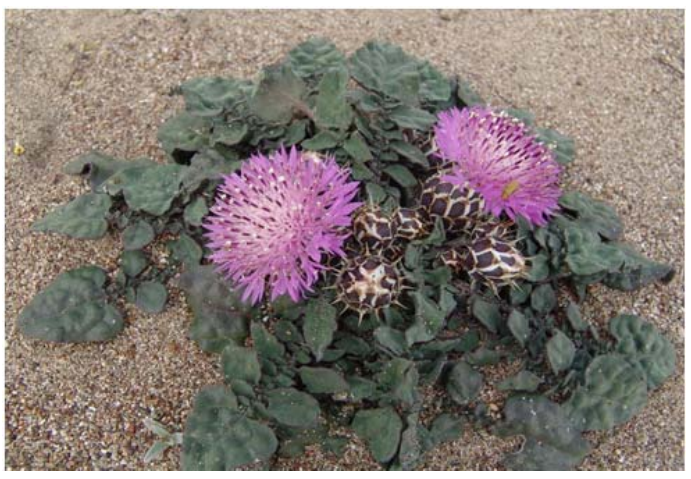

Fig. 9. Centaurea aegialophila ler sarı renkli, anter tüpü pembe-menekşe renkli. Meyve aken. Mayıs ayında çiçeklenen bu tür, ülkemize özgü olup sadece Antalya ve Muğla illerinde yayılış gösterir. Yetişme ortamı olarak kızıçam ormanı ve makilik alanları tercih eder. Akd. El. 


\section{Centaurea iberica Trev. ex Sprengel (deligözdikeni)}

Tek veya iki yıllık bitkiler. Gövde tabanda dallı, 20-100 cm boyunda. Yapraklar seyrek tüylü, pinnatifid veya pinnatisekt parçalı. Çiçekler soluk pembe renkli. Aken meyve 3-4 mm boyunda. Ülkemizin hemen hemen tüm bölgelerinde yetişen bu tür, ülkemiz dışında ise Balkanlar, Kırım ve güney-batı ve orta Asya'da yetişmektedir. Çiçeklenme zamanı haziran-ağustos aylarında olan bu tür yetişme ortamı olarak deniz seviyesinden başlayarak 2300 m'ye kadar olan tarlaları, yol kenarlarını ve nemli alanları tercih eder. ÇBFCB.

Centaurea wagenitzii Hub.-Mor. (adrasan düğmesi) (Olimpos-Beydağları Milli Parkı endemiği) (Fig. 10)

Çok sayıda 5-15 cm boyunda basit gövdeye sahip, tabanda odunlu çok yıllık bitkiler. Yapraklar ilk önce beyaz keçemsi tüylü, sonra çıplak; taban yaprakları pinnatifitden lyrat parçalıya kadar değişir; orta ve üst yapraklar basit, şeritsi. Involukrum yumurtamsı-dikdörtgenimsi. Apendaj hyalin, ortada kahve renkli şeritli, düzensiz saçaklı ve 2-4 $\mathrm{mm}$ boyunda narin bir diken ile sonlanır. Çiçekler sülfür sarısı renkli ve anter tüpü gül-mor renkli. Olimpos-Beydağları Milli Parkına özgü olan bu tür,mayıs ayında çiçeklenir. Yetişme ortamı olarak ise yaklaşık 50 m'ler civarındaki makilikleri tercih eder. Akd. El.

\section{Cichorium intybus L. (hindiba)}

Çok yıllık tüylü veya çıplak bitkiler. Gövde 100

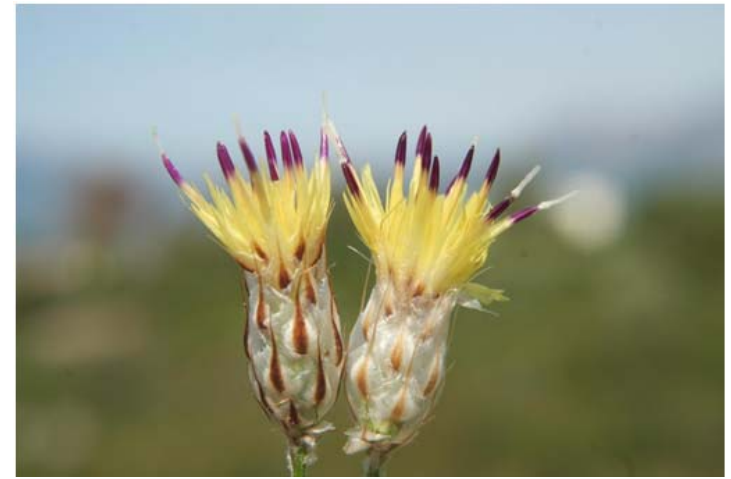

Fig. 10. Centaurea wagenitzii

$\mathrm{cm}$ boyunda. Alt yapraklar saplı, ters mızraksı. Gövde yaprakları alt yapraklara benzer fakat sapsız. Çiçekler gök mavi renkli. Aken meyve ters yumurtamsı, çıplak. Ülkemiz dışında, Avrupa'da, batı Asya'da ve kuzey Avrupa'da yayılış gösterir. Yetişme ortamı olarak deniz seviyesinden başlayarak 3050 m'ye kadar olan kültür tarlaları ve nemli alanları tercih eder. ÇBFCB.

\section{Conyza bonariensis (L.) Cronquist (çakalotu)}

Ilk önce basit daha sonra dallı gövdeye sahip olan tek yıllık otlar. Gövde 60 cm'ye kadar boylanabilir. Alt yapraklar ters mızraksı. Dıştaki çiçekler beyaz, içtekiler ise sarı renkli. Aken meyve dikdörtgenimsi-eliptik. Mayıs-ekim aylarında çiçeklenen bu bitki, yetişme ortamı olarak deniz seviyesinden başlayarak 1070 m'ye kadar olan kuru alanları ve nemli yerleri tercih eder. ÇBFCB.

\section{Echinops onopordum P. H. Davis (öd dikeni) (Antalya endemiği) (Fig. 11a-b)}

Dik gövdeli, basit veya az dallanmış çok yıllık bitkiler. Alt yapraklar kısa saplı, $50 \mathrm{~cm}$ boyunda. Gövde yaprakları sapsız, gövdeyi sarıcı. Kafalar yaklaşık $5 \mathrm{~cm}$ çapında. Çiçekler beyaz renkli. Aken meyve $9 \mathrm{~mm}$ boyunda. Antalya iline özgü olan bu tür, yetişme ortamı olarak, 50-450 m'ler arasındaki, kireç taşlı kayalık yamaçlarda yetişmektedir. Çiçeklenme zamanı ise mayıs-haziran aylarıdır. Akd. El.

\section{Echinops spinossissimus Turra. subsp. bithynicus (Boiss.) Greuter (kirpibaşı)}

2 m'ye kadar boylanabilen çok yıllık bitkiler. Gövde sağlam yapılı, çok dallı. Yapraklar dikdörtgenimsi-mızraksıdan dikdörtgenimsiye kadar değişen şekillerde, 2-3 pinnatisekt parçalı. Kafalar 10 $\mathrm{cm}$ çapına kadar çıkar. Çiçekler mavi, soluk mavi veya beyazımsı renkli. Aken meyve 7-9 mm boyunda. Ülkemiz dışında Yunanistan, Girit ve Sicilya'da yayılış gösteren bu alt tür, haziran-ağus- 


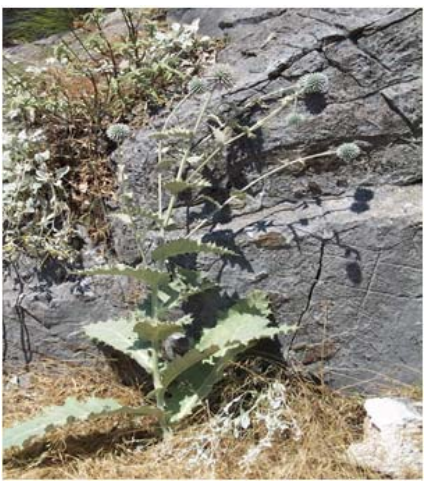

Fig. 11a. Echinops onopordum

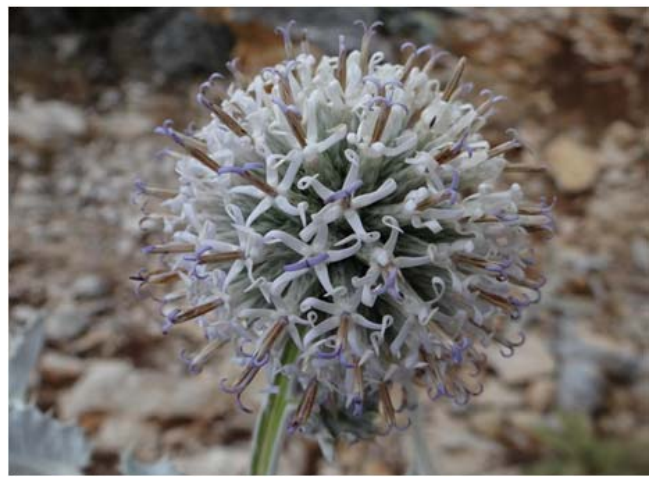

Fig. 11b. Echinops onopordum'un Çiçekli Kapitulasının Yakın Görünüşü.

tos aylarında çiçeklenir. Bu alt tür, yetişme ortamı olarak deniz kıyısındaki kayalıkları, yol kenarlarını ve makilik alanları tercih eder. Ir.-Tur. El.

\section{Helichrysum pamphylicum P. H. Davis \& Kupicha (beyazkurna) (Türkiye endemiği)}

Beyaz-keçemsi tüylü, çok yıllık bitkiler. Gövde dik, dallanmamış 15-60 cm boyunda. Yapraklar şeritsi-ters mıraksı. Çiçekler kar-beyaz. Aken meyve silindirik. Ülkemize özgü olan bu beyazkurna, mayıs-ağustos aylarında çiçeklenir. Yetişme ortamı olarak 20-910 m’ler arasındaki kızılçam ormanlarını ve kireç taşı kayalıklarını tercih eder. Akd. El.

\section{Helichrysum stoechas (L.) Moench subsp. barrelieri (Ten.) Nyman (kudama)}

50 cm'ye kadar boylanabilen çalımsı bitkiler. Gövde alt kısımda çok dallı. Yapraklar darca şeritsi. Kapitula yumurtamsı. Fillariler sarı renkli. Aken meyve silindirik. Ülkemiz dışında İtalya, Balkanlar, Kıbrıs, Lübnan ve kuzey-batı Afrika'da yayılış gösteren bu alt tür, mart-haziran aylarında çiçeklenir. Yetişme ortamı olarak deniz seviyesinden başlayarak 700 m'ye kadar olan kireç taşı makiliklerinde, kızılçam ormanlarında ve kireçli tepelerde yetişmektedir. ÇBFCB.

\section{Inula crithmoides L. (keşir çorağı) (Fig. 12)}

100 cm'ye kadar boylanabilen yarı çalımsı bitkiler. Yapraklar etli, şeritsi-ters mızraksı veya kaşıksı. Tüm çiçekler sarı renkli. Aken meyve basık-beyaz tüylü. Ülkemizde Ege ve Akdeniz kıyılarında ülkemiz dışında ise, batı Avrupa, Avrupa'nın Akdeniz kıyıları ve Tunus'da yayılış göstermektedir. Eylülkasım aralık aylarında çiçeklenen bu bitki, yetişme ortamı olarak, tuzlu bataklıklar ve deniz kenarlarındaki tuzlu alanları tercih eder. ÇBFCB.

\section{Inula heterolepis Boiss. (ak andizotu)}

Kalın odunsu depo köke sahip çok yıllık otlar.

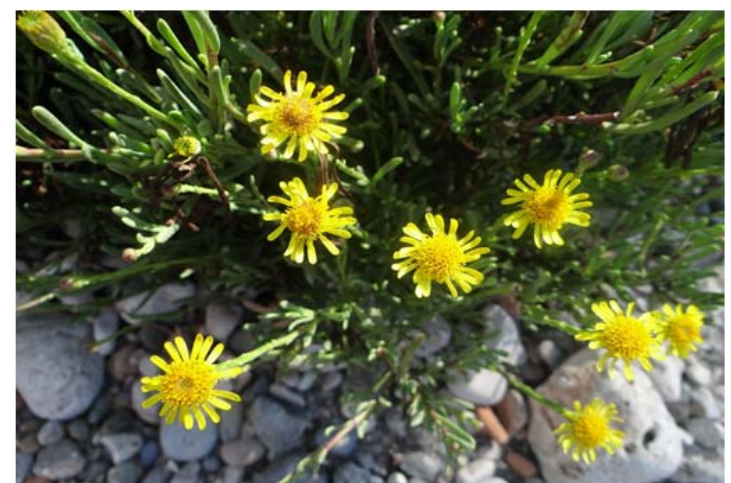

Fig. 12. Inula crithmoides Gövde 15-40 cm boyunda, beyaz yünsü tüylü, üst kısımda dallı. Alt yapraklar yumurtamsı veya eliptik-yumurtamsı. Çiçekler sarı renkli. Aken meyve 1.5-2 mm boyunda, uç kısımda tüylü. Bu tür, yetişme ortamı olarak deniz seviyesinden başlayarak 1500 m’ye kadar olan yüksekliklerdeki kireç taşı kayalıklarını ve yarıklarını tercih eder. Haziran-ağustos aylarında çiçeklenir. Akd. El. 


\section{Lamyropsis cynaroides (Lam.) Dittrich (karakangal)}

Dikenli, çok yıllık nadiren iki yıllık otsu bitkileri. Gövde 35-80 cm boyunda, üst kısımda beyaz örümcek ağsı tüylü. Alt yapraklar pinnatifid parçalı, ters mızraksı. Çiçekler pembemsi-mor renkli. Illk kez Girit Adası'ndan toplanarak bilim dünyasına tanıtılan bu tür, mayıs-temmuz aylarında çiçeklenir. Yetişme ortamı olarak ise deniz seviyesinden başlayarak 800 m'ye kadar olan yüksekliklerdeki kızılçam ormanlarını, deniz kenarlarındaki iri kayalık alanları tercih eder. Akd. El.

Phagnalon graecum Boiss. \& Heldr. (bozçalı)

Dik veya kalkık uçlu çok yıllık bitkiler. Gövde 60 cm'ye kadar boylanabilir, beyaz-keçemsi tüylü. Çiçekler sarı renkli. Aken meyve dikdörtgenimsi. Ülkemizde Ege ve Akdeniz kıyılarında yetişen bu tür, mart-mayıs aylarında çiçeklenir. Yetişme ortamı olarak, 10-150 m’ler arasındaki kayalık yerleri ve sarp kayalıkları tercih eder. Akd. El.

\section{Picnomon acarna (L.) Cass. (kıllçıdiken)}

$150 \mathrm{~cm}$ 'ye kadar boylanabilen, dik, dikenli tek yıllık otsu bitkiler. Yapraklar pinnat parçalı; her parça sert sarı dikenli. Çiçekler pembe, mor renkli, nadiren beyaz ve sarımsı renkli. Aken meyve 5-6 mm boyunda. Bu tür, ülkemizin hemen hemen tüm bölgelerinde yetişmekte olup, Temmuzekim aylarında çiçeklenir. Yetişme ortamı olarak ise 100-1600 m’ler arasındaki yol kenarlarını, stebi ve kuru nehir yataklarını tercih eder. ÇBFCB.

\section{Ptilostemon chamaepeuce (L.) Less. (bozlanotu)}

Dikensiz, 30-100 cm boyunda yuvarlak görünüşlü çalılar. Yapraklar şeritsi. Çiçekli gövde 10-60 $\mathrm{cm}$ boyunda, keçemsi tüylü. Çiçekler mor renkli. Aken meyve ters yumurtamsı. Illk kez Girit Adası'ndan toplanarak bilim dünyasına tanıtılan bu tür, yetişme ortamı olarak deniz seviyesinden başlayarak 850 m’ye kadar olan yüksekliklerdeki sarp kireç taşı kayalıklarını ve nadiren de serpantin alanları tercih eder. Çiçeklenme zamanı ise nisan-haziran aylarıdır. Akd. El.

\section{Pulicaria dysenterica (L.) Bernh. (yaraotu)}

75 cm'ye kadar boylanabilen, rizomlu çok yıllık bitkiler. Yapraklar dikdörtgenimsi-mızraksı, tabanda kalpsi kulakçıkı. Dilsi çiçekler çok sayıda sarı renkli. Aken meyve dikdörtgenimsi. Ülkemizin hemen hemen tüm bölgelerinde geniş yayılış alanına sahip olan bu tür, temmuz-eylül aylarında çiçeklenir. Bu bitki, yetişme ortamı olarak deniz seviyesinden başlayarak 1600 m'ye kadar olan yüksekliklerdeki dere ve nehir yataklarını tercih eder. ÇBFCB.

\section{Scolymus hispanicus L. subsp. hispanicus (şevketi bostan)}

70 cm'ye kadar boylanabilen yoğun dallı, dikenli iki veya çok yıllık otsu bitkiler. Yapraklar yumurtamsıdan dikdörtgenimi-mızraksıya kadar değişen şekillerde. Çiçekler sarı renkli. Aken meyve 3-5 mm boyunda. Yetişme ortamı olarak deniz seviyesinden başlayarak 1600 m’ye kadar olan yüksekliklerdeki yol kenarlarını ve açık alanları tercih eder. Çiçeklenme zamanı ise haziran-ağustos aylarıdır. Bitkinin toprak üstündeki kısmı genç iken sebze olarak, kökü ise idrar artırıcı olarak kullanıı.ır. Akd. El.

\section{Senecio vernalis Waldst. \& Kit. (kanaryaotu)}

Dik gövdeli tek yıllık otsu bitkiler. Gövde 70’ye kadar çıkar, genç iken tüylü. Alt yapraklar yumurtamsıdan dikdörtgenimsiye kadar değişen şekillerde dişli veya pinnatifid loplu. Dilsi ve tüpsü çiçekler sarı renkli. Aken meyve basık tüylü. Yetişme ortamı olarak deniz seviyesinden başlayarak 3000 m'ye kadar olan yüksekliklerdeki kumlu ve nemli alanları, tarlaları, kayalık yamaçları tercih eden bu tür, şubat-ağustos aylarında çiçeklenir. ÇBFCB. 


\section{Sonchus asper (L.) Hill subsp. glaucescens (Jordan) Ball (gevirtlek)}

Çıplak veya üst kısımda salgıı tüylü tek veya iki yıllık otsu bitkiler. Gövde 10-150 cm boyunda. Yapraklar genellikle tabanda rozet şeklinde, tam kenarlı veya pinnatifid parçalı. Çiçekler sarı renkli. Aken meyve elipsoid ve kanatlı. Bu alt tür mart-ağustos aylarında çiçeklenir ve yetişme ortamı olarak deniz seviyesinden başlayarak 700 m'ye kadar olan yüksekliklerdeki orman açıklıklarını, kumlu alanları ve kültür alanlarını tercih eder. ÇBFCB.

Tragopogon porrifolius L. subsp. abbreviatus (Boiss.) Coşkunçelebi \& M. Gültepe (çayır yemliği)

80 cm'ye kadar boylanabilen tüylü veya çıplak iki yıllık bitkiler. Yapraklar şeritsi. Çiçekler soluk leylak veya koyu menekşe renkli. Meyve aken. Nisan-temmuz aylarında çiçeklenen bu alt tür yetişme ortamı olarak deniz seviyesinden başlayarak 2300 m'ye kadar olan yüksekliklerdeki kayalık yamaçları, yol kenarlarını ve tarlaları tercih eder. ÇBFCB.

\section{Xanthium orientale L. subsp. italicum (Moretti) Greuter (domuz pıtrağı)}

Sağlam yapılı, $180 \mathrm{~cm}$ boyunda tek yıllık otsu bitkiler. Yapraklar uzun saplı, kamamsı-yumurtamsı. Meyveli involukrum 15-30 cm boyunda, yoğun çengelli dikenli. Bu alt tür, yetişme ortamı olarak deniz seviyesinden başlayarak 250 m'ye kadar olan yüksekliklerdeki tarla kenarlarını ve kumlu alanları tercih eder. ÇBFCB.

Familya: Boraginaceae (Hodangiller)

Anchusa hybrida Ten. (tatlıbaba)

Tek veya iki çok yıllık, sert kıllı otsu bitkiler. Gövde dik veya yayılııı, 15-40 cm boyunda. Yapraklar mızraksıdan eliptiğe kadar değişen şekillerde, dalgalı-dişli kenarlı. Korolla menekşeden koyu mora kadar değişen renklerde veya beyaz renkli. Meyve fındıksı. Ülkemizin büyük bir kısmında yetişen bu bitki, mart-mayıs aylarında çiçeklenir. Yetişme ortamı olarak deniz seviyesinden başlayarak 900 m'ye kadar olan yüksekliklerdeki kızılçam ormanlarını, kum tepelerini ve nemli yerleri tercih eder. Akd. El.

\section{Cynoglossum creticum Mill. (pisiktetiği)}

Tüylü, 20-80 cm boyunda, dik gövdeli, iki yıllık otsu bitkiler. Yapraklar eliptikten darca mızraksıya kadar değişen şekillerde. Korolla pembe veya beyazımsı daha sonra soluk veya koyu mavi renge döner. Fındıksı meyve yumurtamsı-basık küresel. Ülkemizin hemen hemen tüm bölgelerinde yetişen bu tür, mart-temmuz aylarında çiçeklenir. Yetişme ortamı olarak deniz seviyesinden başlayarak 1000 m’ye kadar olan yüksekliklerdeki kireç taşlı kayalık yamaçları, yol kenarlarını, kumlu yamaçları ve nemli yerleri tercih eder. ÇBFCB.

\section{Echium angustifolium Mill. (engerek otu)}

13-60 cm boyunda, odunsu köklü, çok yıllık otsu bitkiler. Gövde beyaz-sert kıllı, 1-çok sayıda. Yapraklar dar şeritsi, mızraksı, dikdörtgenimsi veya dar eliptik. Korolla mavi, morumsu, leylak veya kırmızı renkli. Fındıksı meyve dikdörtgenimsi-ters piramidal. Ülkemizin Ege, Akdeniz, Karadeniz ve Marmara Bölgeleri'nde yetişen bu tür, mart-ağustos (-aralık) aylarında çiçeklenir. Yetişme ortamı olarak deniz seviyesinden başlayarak 870 m'ye kadar olan yüksekliklerdeki kıyı kumullarını, kumul yamaçları, makilikleri, stebi ve çalılık alanları tercih eder. Akd. El.

\section{Echium italicum L. (kurtkuyruğu)}

Dik gövdeli, 90 cm'ye kadar boylanabilen, sert dikenli, iki yıllık bitkiler. Yapraklar şeritsiden dar dikdörtgenimsiye kadar değişen şeklerde. Korolla soluk mavi, leylak, pembemsi veya beyaz 
renkli. Fındıksı meyve dikdörtgenimsi. Ülkemizin hemen hemen tüm bölgelerinde yayılış gösteren bu kurtkuyruğu, yetişme ortamı olarak deniz seviyesinden başlayarak 1950 m’ye kadar olan yüksekliklerdeki kireç taşlı yamaçları, tarlaları ve tahrip edilmiş alanları tercih eder. Çiçeklenme zamanı mayıs-ağustos aylarıdır. Akd. El.

\section{Heliotropium hirsutissimum Grauer (aygün çiçeği)}

Dallı tek yıllık otsu bitkiler. Yapraklar yumurtamsıdan yumurtamsı-mızraksıya kadar değişen şekillerde. Korolla tüp kısmı sarı, lopları tekerlek biçimli ve beyaz renkli. Fındıksı meyve çıplak. Geniş bir yayılış alanına sahip olan bu tür, yetişme ortamı olarak deniz seviyesinden başlayarak 2200 m’ye kadar olan yüksekliklerdeki tarlaları, tarla kenarlarını ve nemli yerleri tercih eder. Çiçeklenme zamanı ise mayıs-ekim ayları arasında çiçeklenir. Akd. El.

\section{Onosma frutescens Lam. (sarı emcek)}

Rizomlu, çok yıllık bitkiler. Gövde 10-40 cm boyunda, eğik tırmanışlı. Yapraklar şeritsi-kaşıksı. Korolla ilk önce sarı, daha sonra altın sarısı, turuncu, kırmızımsı veya kahverengimsiye döner. Fındıksı meyve yumurtamsı. Bu tür, ülkemiz dışında batı Suriye'de, ülkemizde ise Akdeniz Bölgesi'nde yayılış gösterir. Mart-haziran aylarında çiçeklenen bu tür, yetişme ortamı olarak deniz seviyesinden başlayarak 1200 m'ye kadar olan yüksekliklerdeki kireç taşı kaya yarıklarını tercih eder. Akd. El.

\section{Onosma oreodoxa Boiss. \& Heldr. (darı şincarı)}

Dik veya yükselici, 25-65 cm boyunda çok yıllık bitkiler. Taban yaprakları dikdörtgenimsiden dar eliptiğe kadar değişen şekillerde; gövde yaprakları kaşıksı-dikdörtgenimsi-mızraksı: korolla beyazımsı-kirli beyaz. Fındıksı meyve yumurtamsı. Mayıs ayında çiçeklenen bu bitki, yetişme ortamı olarak 110-1090 m'ler arasındaki kayalık yerleri, makilikleri ve mısır tarlalarını tercih eder. Ülkemizde Burdur ve Antalya ilinde, ülkemiz dışında kuzey Irakta yetişir. Akd. El.

Onosma strigosissima Boiss. (yalı şincarı) (Antalya endemiği) (Fig. 13)

Yarı kümeli, uzun sert dikenli, $10-20 \mathrm{~cm}$ boyunda çok yıllık bitkiler. Yapraklar mızraksıdan şeritsi-ters mızraksıya kadar değişen şekillerde. Korolla sarı renkli. Fındıksı meyveler genişçe yumurtamsı. Ülkemize özgü olan bu tür, sadece Antalya ilinde yayılış göstermektedir. Nisan ayında çiçeklenen bu yalı şincarı, deniz kenarlarındaki kireç taşlı kayalıkları ve kızılçam ormanlarını tercih eder. Akd. El.

Familya: Brassicaceae (Turpgiller)

Alyssum hirsutum Bieb. subsp. caespitosum

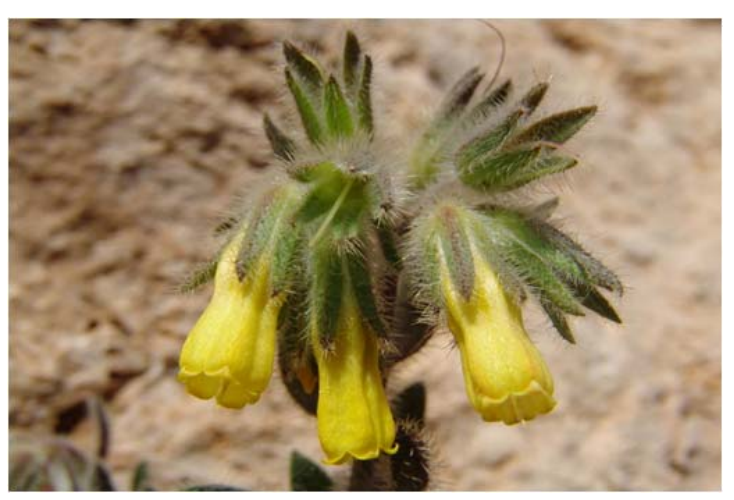

Fig. 13. Onosma strigosissima

\section{(T. R. Dudley) Ancev, Kozuharov \& Kuzmanov (kıllıdemet) (Türkiye endemiği)}

Tek yıllık kümeli otsu bitkiler. Yapraklar ters mızraksıdan ters yumurtamsıya kadar değişir. Çiçek durumu yoğun şemsiye gibi. Sepaller düşücü. Petaller sarı renkli, iki loplu. Meyve 5-6 mm eninde ve boyunda, uzun, yoğun ve tabanda memecikli tüylü. Ülkemize özgü olan bu alt tür, Eskişehir, Burdur, Antalya ve Kayseri illerinde yetişmektedir. Mayıs-haziran aylarında çiçeklenmekte olup stebi ve dağlık yamaçları tercih eder. Ir.-Tur. El. 


\section{Alyssum pterocarpum T. R. Dudley (yüce kevke) (Türkiye endemiği)}

Sağlam yapılı, kırmııımsı, 1 m’ye kadar boylanabilen çalımsı çok yıllık bitkiler. Verimsiz sürgün yaprakları tersyumurtamsı-kaşıksı; gövde yaprakları ters yumurtamsı veya ters mızraksı. Petaller sarı renkli. Meyve silikula. Ülkemize özgü olan bu tür, sadece Antalya ve Muğla illerinde yetişir. Nisan-temmuz aylarında çiçeklenmekte olup, yetişme ortamı olarak deniz seviyesinden başlayarak 250 m'ye kadar olan yüksekliklerdeki açık alanları tercih eder. Akd. El.

\section{Arabis ionocalyx Boiss. (morçanak)}

Dik gövdeli, $15-35 \mathrm{~cm}$ boyunda, tek veya iki yıllık otsu bitkiler. Taban yaprakları ters yumurtamsıkaşıksı; gövde yaprakları dikdörtgenimsi-mızraksı. Sepaller morumsu renkli. Petaller beyaz renkli. Meyve yayılııı, kıvrık ve yarı basık. Ülkemizde Antalya ve Mersin illerinde, ülkemiz dışında ise batı Suriye'de yayılış gösteren bu tür, yetişme ortamı olarak 500-1900 m’ler arasındaki yamaçları, kayalıkları ve ormanları tercih eder. Çiçeklenme zamanı ise mart ve nisan aylarıdır. Akd. El.

\section{Biscutella didyma L. (çıtçıtotu)}

40 cm'ye kadar boylanabilen tek yıllık otlar. Gövde basit veya çok dallı. Alt yapraklar kamamsıters yumurtamsı, dişli kenarlı. Petaller sarı renkli. Meyveler ikiz şeklinde, her biri dairesel. Bu tür, ülkemizde İzmir, Muğla ve Antalya illerinde, ülkemiz dışında ise güney Avrupa, batı Suriye, kuzey Irak ve batı İran'da yayılış göstermektedir. Mart-haziran aylarında çiçeklenmekte olup, yetişme ortamı olarak deniz seviyesinden başlayarak 400 m’ye kadar olan yüksekliklerdeki kayalık yamaçları, kireç taşı ve serpantin alanları tercih eder. ÇBFCB.

\section{Cakile maritima Scop. (kumteresi)}

Su depo eden tek yıllık bitkiler. Gövde sürünücü veya eğik tırmanışlı ve 40 cm'ye kadar boylanır. Yapraklar pinnat veya pinnatifid parçalı; loplar dikdörtgenimsi. Petaller beyaz, leylak veya gül renkli. Meyve 20-25 mm boyunda, çıplak. Yetişme ortamı olarak deniz kenarındaki kumulları tercih eden bu tür, haziran-ağustos aylarında çiçeklenir. ÇBFCB.

\section{Capsella bursa-pastoris (L.) Medik. (çobançantası)}

$50 \mathrm{~cm}$ 'ye kadar boylanabilen, tek veya iki yıllık otsu bitkiler. Taban yaprakları rozet şeklinde, lirat, pinnatifit veya tam kenarlı. Petaller beyaz veya pembe renkli. Kozmopolit bir tür olan bu bitki yetişme ortamı olarak deniz seviyesinden başlayarak 2000 m’ye kadar olan yüksekliklerdeki kültür alanlarını ve nemli yerleri tercih eder. Çiçeklenme zamanı ise tüm yıl boyudur. ÇBFCB.

\section{Clypeola jonthlaspi L. (akçeotu)}

30 cm'ye kadar boylanabilen basit veya dallı bir yıllık otsu bitkiler. Yapraklar dar mıraksıdan kaşıksıya kadar değişen şekillerde. Petaller sarı renkli. Meyve eliptikten dairesele kadar değişen şekillerde. Nisan ve mayıs aylarında çiçeklenen bu tür, yetişme ortamı olarak deniz seviyesinden başlayarak 1300 m'ye kadar olan yüksekliklerdeki kayalık yerleri ve kayalık yamaçları tercih eder. Akd. El.

\section{Conringia grandiflora Boiss. \&. Heldr. (iritelkari) (Antalya endemiği) (Fig. 14)}

Basit veya tabanda dallı, 20 cm'ye kadar boylanabilen tek yıllık otsu bitkiler. Yapraklar dikdörtgenimsi-yumurtamsı. Petaller sarı renkli. Meyve dik. Ülkemize özgü olan bu tür sadece Antalya ilinde yayılış gösterir. Mart-mayıs aylarında çiçeklenen bu tür, yetişme ortamı olarak ise 3001000 m’ler arasındaki kireç taşı kayalık yamaçları tercih eder. Akd. El. 


\section{Draba verna (L.) Chevall (çırçırotu)}

2-22 cm boyunda, dik veya eğik tırmanışlı tek yıllık bitkiler. Yapraklar kaşıksı, mızraksı veya ters yumurtamsı. Petaller beyaz renkli. Meyve ters mıraksı veya eliptik. Ülkemizin hemen hemen tüm bölgelerinde yayılış gösteren bu tür, yetişme ortamı olarak deniz seviyesinden başlayarak 1300 m'ye kadar olan yüksekliklerdeki yamaçları tercih eder. Çiçeklenme zamanı ise marthaziran aylarıdır. ÇBFCB.

Fibigia clypeata (L.) Medik. subsp. clypeata var. eriocarpa (DC.) Post (sikkeotu)

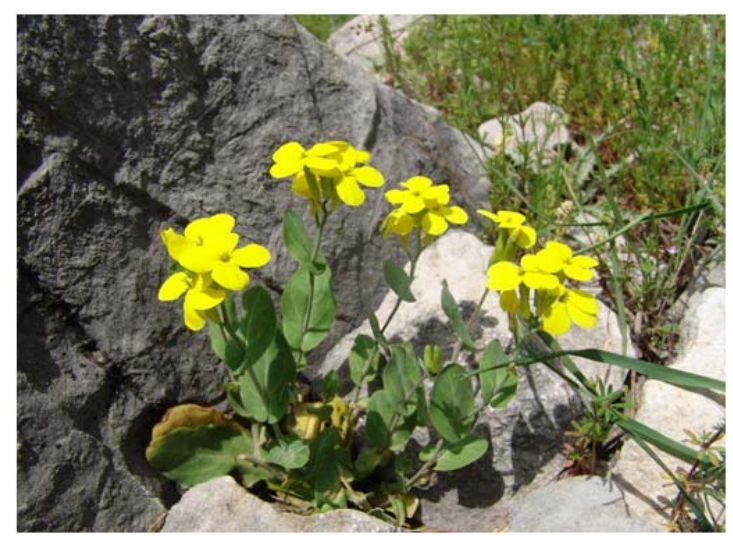

Fig. 14. Conringia grandiflora

30 cm'ye kadar boylanabilen yarı çalımsı çok yıllık otlar. Yapraklar şeritsi-dikdörtgenimsi. Petaller sarı renkli. Meyve dikdörtgenimsi-eliptik veya yumurtamsı-dikdörtgenimsi. Illk kez Kıbrıs'tan toplanarak bilim dünyasına tanıtılan bu varyete, nisan-mayıs aylarında çiçeklenir.Yetişme ortamı olarak ise 100-2000 m'ler arasındaki yamaçları, çalııkları ve ormanları tercih eder. ÇBFCB.

\section{Hirschfeldia incana (L.) Lagr.-Foss. (nadas turpu)}

Iki yıllık nadiren tek yıllık otsu bitkiler. Gövde 20-100 cm boyunda, tabanda yarı basit veya dallı. Taban yaprakları rozet formunda, lirat parçalı, üst yapraklar tam kenarlı. Petaller sarı renkli. Meyve çıplak. Yetişme ortamı olarak deniz seviyesinden başlayarak 900 m'ye kadar olan yüksekliklerdeki tarlaları ve nemli alanları tercih eden bu tür, nisan-temmuz aylarında çiçeklenir. ÇBFCB.

\section{Raphanus raphanistrum L. (eşek turpu)}

Genellikle tabanda dallı, $15-50 \mathrm{~cm}$ boyunda tek yıllık otsu bitkiler. Taban yaprakları lirat parçalı. Gövde yaprakları saplı. Petaller beyaz, soluk gül, leylak veya sarı, genellikle çizgili. Meyve dikyükselici, 1.4-6.5 cm boyunda. Mart-mayıs aylarında çiçeklenen bu tür, yetişme ortamı olarak deniz seviyesinden başlayarak 400 m’ye kadar olan yüksekliklerdeki kültür alanlarını, tarlaları ve kumlu tarlaları tercih eder. ÇBFCB.

\section{Ricotia carnosula Boiss.\& Heldr. (dişli cavlak) (Türkiye endemiği) (Fig. 15)}

Yeşilimsi pulsu ve çıplak tek yıllık otsu bitkiler. Yapraklar pinnat parçalı; segmentler üç parçalı ve pinnatisekt, şeritsi, şeritsi-dikdörtgenimsi veya yumurtamsı. Petaller beyazdan soluk leylak rengine kadar değişen renklerde, (10-)11-12 mm boyunda. Silikuva meyve şeritsi-mızraksı, 12 tohuma kadar çıkar. Ülkemize özgü olan bu tür, Antalya, Muğla ve Adana illerinde yayılış göstermekte olup, mart ve nisan aylarında çiçeklenir. Yetişme ortamı olarak ise deniz seviyesinden başlayarak 700 m'ye kadar olan yüksekliklerdeki kayalık yerleri tercih eder. Akd. El.

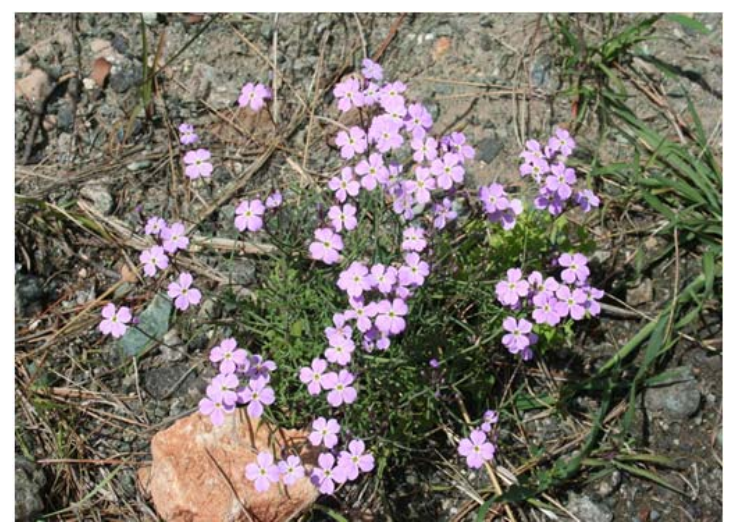

Fig. 15. Ricotia carnosula 
Familya: Campanulaceae (Çançiçeğigiller)

Campanula delicatula Boiss. (narin çan)

Narin yapılı, 20 cm'ye kadar boylanabilen tek yıllık otsu bitkiler. Yapraklar yumurtamsı. Korolla dar silindirik, mavimsi. Kapsül meyve ters konik. Ülkemizde Ege ve Akdeniz Bölgeleri'nde, ülkemiz dışında ise Yunanistan ve Kıbrıs'ta yayılış gösteren bu tür, nisan-haziran aylarında çiçeklenir. Bu bitki, 10-900 m’ler arasındaki kireç taşlı kayalıkları, duvarları ve kuru yerleri tercih eder. Akd. El.

Campanula lyrata Lam. subsp. lyrata (memek) (Fig. 16)

Dik veya eğik yükselişli, yarı sert tüylü, 15-50 cm boyunda iki veya çok yıllık otsu bitkiler. Taban yaprakları lirat veya dikdörtgenimsi-yumurtamsı. Korolla silindirik-dar hunimsi, tüp 12-20 mm boyunda, menekşe-mavi renkli. Meyve kapsül. Nisan-temmuz ayında çiçeklenen bu bitki, yetişme ortamı olarak deniz seviyesinden başlayarak 1700 m’ye kadar olan yüksekliklerdeki taşık alanları, çam ormanı açıkıkları ve uçurumları tercih eder. ÇBFCB.

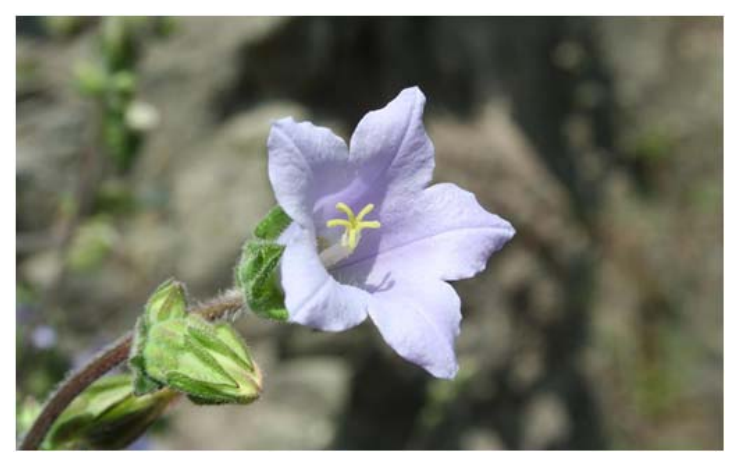

Fig. 16. Campanula lyrata subsp. lyrata

\section{Legousia speculum-veneris (L.) Chaix (hoş kadınaynası)}

10-30 cm boyunda tek yıllık otsu bitkiler. Gövde dik, genellikle dallı. Yapraklar yumurtamsıdan yumurtamsı-mızraksıya kadar değişen şekillerde. Kaliks lopları şeritsi-mızraksı. Korolla menekşe renkli. Meyve kapsül. Ülkemizde geniş bir yayılış alanına sahip olan bu tür, 1900 m’ye kadar olan yüksekliklerdeki sarıçam ormanlarını, tarlaları ve açık alanları tercih eder. Çiçeklenme zamanı ise nisan-mayıs aylarıdır. ÇBFCB.

\section{Familya: Capparaceae (Keberegiller)}

Capparis spinosa L. (kebere) (Fig. 17)

Düzensiz yapılı, dikenli çalılar. Yapraklar dairesel veya geniş̧̧e yumurtamsı. Çiçekler gösterişli. Sepaller 4 adet. Petaller beyaz renkli. Stamenler çok sayıda ve uzun. Meyve etli ve çok tohumlu kapsül. Kültür alanlarındaki nemli yerleri, maki açıklıklarını, yol ve tarla kenarlarını, denize yakın yerlerdeki kayalıkları yetişme ortamı olarak tercih eden bu bitki mayıs-temmuz aylarında çiçeklenir. ÇBFCB.

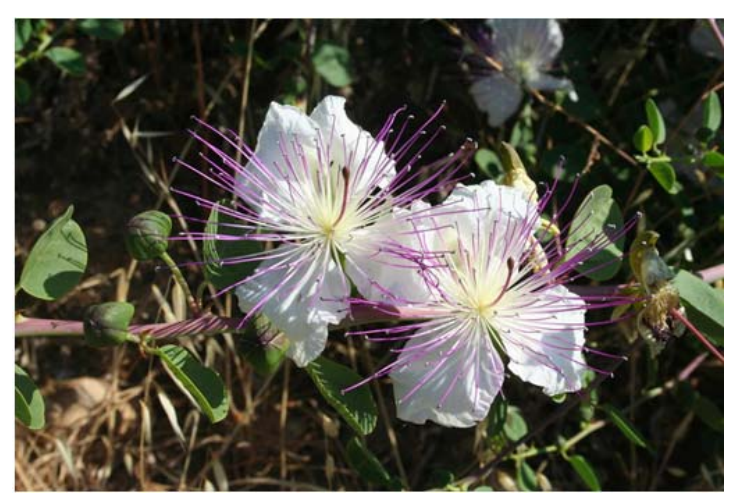

Fig. 17. Capparis spinosa

\section{Familya: Caprifoliaceae (Hanımeligiller)}

\section{Lonicera etrusca Santi var. etrusca (hanımeli)}

3-4 m boyunda, odunlu tırmanıcı bitkiler. Yapraklar ters yumurtamsıdan yumurtamsıya kadar değişir. Çiçek durumu uçta, 4-10 çiçekli. Korolla sarımsı, 30-50 mm boyunda. Üzümsü meyve kırmızı. Mayıs ve haziran ayında çiçeklenen bu varyete, yamaçları, yol kenarlarını, çalı aralarını, bazen de kültür alanlarını yetişme ortamı olarak tercih eder. ÇBFCB. 


\section{Pterocephalus plumosus (L.) Coulter (gök cücükotu)}

50 cm'ye kadar boylanabilen, dik gövdeli tek yıllık otsu bitkiler. Alt yapraklar dikdörtgenimsi veya pinnatisekt parçalı. Involukral brakteler mızraksı. Korolla leylak renkli. Meyveli involusel 4-6 mm boyunda, ana damar üzerleri salgılı tüylü. Kaliks 10-15 setalı. Ülkemizde geniş bir yayılış alanına sahip olan bu tür, yetişme ortamı olarak deniz seviyesinden başlayarak 1700 m'ye kadar olan yüksekliklerdeki taşlı yamaçları ve yol kenarlarını tercih eder. Çiçeklenme zamanı ise mayısağustos aylarıdır. ÇBFCB.

\section{Familya: Caryophyllaceae (Karanfilgiller)}

\section{Dianthus orientalis Adams, Weber \& Mohr (yar karanfili)}

Tabanda odunlu, 15-40 cm boyunda çok yıllık bitkiler. Yapraklar şeritsi. Çiçekler genellikle tek. Kaliks 17-21(-24) mm boyunda. Petal dudakları pembe, saçaklı, ince püsküllü. Bu tür, yetişme ortamı olarak 500-3160 m'ler arasındaki sarp kayalıkları, kayalık yamaçları ve kaya yarıklarını tercih etmekte olup, haziran-eylül aylarında çiçeklenmektedir. ÇBFCB.

\section{Dianthus tripunctatus $\mathrm{Sm}$. (benekli karanfil)}

20-50 cm boyunda, tek yıllık otsu bitkiler. Alt gövde yaprakları şeritsi. Çiçek durumu uç kısımda tek çiçekle sonlanır. Brakteol 4 adet. Kaliks $18-20 \mathrm{~cm}$ boyunda. Petal dudaklarıpembe, benekli, tabanda sarımsı, ince püsküllü, dişli kenarlı. Meyve kapsül. Ülkemizde Balıkesir, İzmir, Aydın, Muğla ve Antalya illerinde yetişen bu tür, mayıs-haziran aylarında çiçeklenir ve 70 m’ye kadar olan yüksekliklerdeki yol kenarlarında, tarlalarda ve yamaçlarda yetişir. Akd. El.

\section{Minuartia picta (Sibth. \& Sm.) Bornm. (ergen tıstıs)}

12 cm'ye kadar boylanabilen çıplak veya yoğun salgıı tüylü tek yıllık otsu bitkiler. Yapraklar kılsı. Sepaller 2-2.5 mm boyunda, yumurtamsı-dairesel. Petaller pembe veya nadiren beyaz. Kapsül meyve yumurtamsı. Bu tür, ülkemizde Antalya, Gaziantep ve Şanlıurfa illerinde, ülkemiz dışında ise güneybatı Asya'da yayılış göstermektedir. Yetişme ortamı olarak deniz seviyesinden başlayarak 1800 m'ye kadar olan yüksekliklerdeki tarlaları, kumul alanları, stebi ve yarı çöl alanları tercih etmekte olup şubat-nisan aylarında çiçeklenir. ÇBFCB.

\section{Silene aegyptiaca (L.) L. fil. subsp. aegyptiaca (ballıca)}

Hemen hemen dik gövdeli, 7-30 cm boyunda tek yıllık otsu bitkiler. Alt yapraklar saplı, dikdörtgenimsi-kaşıksıdan dairesele kadar değişen şekillerde. Kaliks 13-18 mm, mor renkli. Petaller pembe renkli. Antofor 7-11 mm boyunda ve çılak. Kapsül meyve dikdörtgenimsi. Ülkemizde sadece Akdeniz Bölgesi'nde yetişen bu alt tür, yetişme ortamı olarak deniz seviyesinden başlayarak 2000 m'ye kadar olan yüksekliklerdeki yamaçları, tarlaları ve yol kenarlarını tercih eder. Çiçeklenme zamanı ise şubat-mayıs aylarıdır. Akd. El.

\section{Silene dichotoma Ehrh. subsp. dichotoma (çatal nakıl)}

Tek veya nadiren iki veya çok yıllık otsu bitkiler. Gövde tüylü, eğik tırmanışlı veya dik, 15-80 cm boyunda. Gövde yaprakları sapsız, mızraksıdan dikdörtgenimsi-mızraksıya kadar değişen şekillerde. Kaliks 7-15 mm boyunda. Petaller beyaz renkli ve derin iki parçalı. Antofor $1.5-2 \mathrm{~mm}$ boyunda ve çıplak. Kapsül meyve yumurtamsı-dikdörtgenimsi. Mayıs-temmuz aylarında çiçeklenen bu alt tür, yetişme ortamı olarak ise deniz seviyesinden başlayarak 2100 m'ye kadar olan yüksekliklerdeki yamaçları ve stebi tercih eder. ÇBFCB. 


\section{Silene gallica L. (serçeçiçeği)}

10-45 cm boyunda, dik, tüylü tek yıllık bitkiler. Alt yapraklar saplı, dikdörtgenimsi-kaşıksı. Kaliks 9-11 mm boyunda, tüylü. Petaller pembe veya beyaz renkli. Antofor 1-1.5 mm boyunda. Kapsül meyve yumurtamsı-konik. Kozmopolit bir tür olan bu serçeçiçeği bitkisi, yetişme ortamı olarak ise deniz seviyesinden başlayarak 400 m'ye kadar olan yüksekliklerdeki tarlaları ve çalılık alanları tercih eder. Çiçeklenme zamanı ise nisan-haziran aylarıdır. ÇBFCB.

\section{Silene gigantea L. var. rhodopea (Janka) Greuter (koca nakıl)}

İki veya çok yıllık otsu bitkiler. Gövde $60-100 \mathrm{~cm}$ boyunda. Taban yaprakları kaşıksı, ters yumurtamsı veya yers mızraksı. Kaliks henem hemen tüpsü, çiçekte 6-7 mm boyunda. Petaller soluk sarımsıdan yeşilimsiye kadar değişen renklerde, derin iki parçalı. Antofor 2-4.5 mm boyunda. Meyve kapsül. Bu varyete ülkemizde Antalya, Muğla ve Manisa illerinde, ülkemiz dışında ise Yunanistan, Lübnan ve Ege Adaları́nda yayılış gösterir. Yetişme ortamı olarak 150-1200 m’ler arasındaki açık kayalık yerleri tercih etmekte olup nisan-temmuz aylarında çiçeklenir. Akd. El.

\section{Silene kotschyi Boiss. var. maritima Boiss. (deniz nakılı)}

Eğik tırmanışlı veya dik gövdeli, 20 cm'den kısa tek yıllık otsu bitkiler. Taban yaprakları şeritsimızraksıdan ters mızraksıya kadar değişen şekillerde. Gövde yaprakları şeritsi-mızraksı. Kaliks 8$11 \mathrm{~mm}$ boyunda, tüylü. Petaller beyaz veya pembe renkli. Antofor 2.5-7 mm boyunda. Kapsül meyve yumurtamsı-küresel. Yetişme ortamı olarak deniz kenarındaki kumul alanları tercih eden bu varyete mayıs-temmuz aylarında çiçeklenir. Akd. El.

\section{Familya: Cistaceae (Ladengiller)}

\section{Cistus creticus L. (Girit ladeni) (Fig. 18)}

0.3-1 m boyunda çalılar. Yapraklar yumurtamsı, dikdörtgenimsi-ters yumurtamsı veya yarı dairesel. Korolla pembe renkli. Kapsül meyve yoğun basık tüylü. Bilim dünyası'na ilk kez Girit Adası'ndan toplanarak tanıtılan bu laden türü, ülkemiz dışında Kırım, orta Avrupa ve Gürcistan'da da yayılış göstermektedir. Yetişme ortamı olarak deniz seviyesinden başlayarak 1000 m'ye kadar olan yüksekliklerdeki makilik alanları ve frigana'yı tercih eder. Çiçeklenme zamanı ise mart-haziran aylarıdır. ÇBFCB.

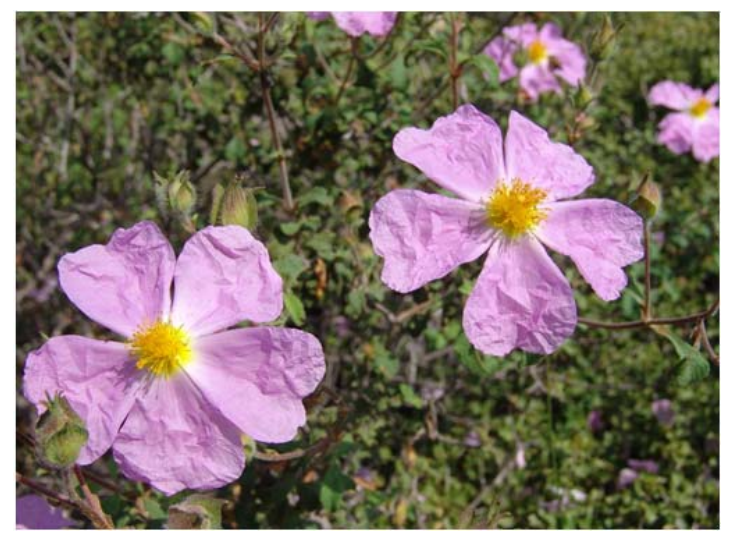

Fig. 18. Cistus creticus

\section{Cistus salviifolius L. (kartli)}

50 cm'ye kadar boylanabilen küçük çalılar. Yapraklar yumurtamsı-eliptik, üst ve alt kısımda yıldızsı tüylü. Korolla beyaz renkli. Kapsül meyve yoğun basık tüylü. Mart-mayıs aylarında çiçeklenen bu tür, en fazla 500 m'ye kadar olan yüksekliklerdeki deniz kıyısındaki tepelikleri, kalkerli makilik alanları ve frigana'yı tercih eder. ÇBFCB.

\section{Familya: Convolvulaceae (Tarlasarmaşığıgiller)}

\section{Convolvulus arvensis L. (tarla sarmaşığı, mahmuz, çadır çiçeği)}

Sürünücü veya tırmanıcı çok yıllık otsu bitkiler. Yapraklar okbaşı veya zıpkınsı. Çiçekler genellikle tek. Korolla beyaz veya pembe, nadiren mavi renkli. Meyve kapsül. Ülkemizde oldukça geniş bir yayılış alanına sahip olan bu tür, nisan-eylül aylarında çiçeklenir. Yetişme ortamı olarak deniz 
seviyesinden başlayarak 1900 m’ye kadar olan yüksekliklerdeki kumlu stebi, tarlaları, nehir ve göl kenarlarını, kumulları ve yol kenarlarını tercih eder. ÇBFCB.

\section{Convolvulus cantabrica L. (çadır çiçeği)}

Tabanda odunlu çok yıllık otsu bitkiler. Gövde yatık gövdeli, dik veya eğik tırmanışlı, $10-45 \mathrm{~cm}$ boyunda. Alt yapraklar dikdörtgenimsi-kaşıksı. Üst yapraklar ters mızraksıdan şeritsiye kadar değişen şekillerde. Korolla pembe, nadiren beyaz renkli. Meyve kapsül. Nisan-ağustos aylarında çiçeklenen bu tür, yetişme ortamı olarak deniz seviyesinden başlayarak 1700 m'ye kadar olan yüksekliklerdeki makilikleri, kızılçam altlarını, kayalıkları ve yol kenarlarını tercih eder. Akd. El.

\section{Familya: Crassulaceae (Damkoruğugiller)}

\section{Rosularia globulariifolia (Fenzl) A. Berger (top kayakoruğu)}

Çok yıllık otsu bitkiler. Çiçek kümesi gövdesi $10-20 \mathrm{~cm}$ boyunda. Yapraklar ters mızraksı-kaşıksı, yumuşak tüylü. Çiçek durumu sık bileşik salkım, 75-250 çiçekli. Kaliks 5-8 mm boyunda, yumurtamsı. Korolla 6-8 mm boyunda, beyaz renkli. Folikül meyve salgılı tüylü. Ülkemizde Muğla, Antalya, Mersin ve Hatay illerinde yayılış göstermekte olan bu tür, mayıs-haziran aylarında çiçeklenir. Yetişme ortamı olarak ise 10-1000 m'ler arasındaki kireç taşlı kayalıkları tercih eder. Akd. El.

\section{Sedum sediforme (Jacq.) Pau (yalı koruğu)}

25-60 cm boyunda, eğik tırmanışı, tabanda odunsu çok yıllık bitkiler. Yapraklar dikdörtgenimsiden darca eliptiğe kadar değişen şekillerde. Çiçek durumu çok çiçekten oluşan kimöz. Çiçekler 5(-6) parçalı, hemen hemen sapsız veya kısa saplı. Sepaller 3-4 mm boyunda. Petaller 6-7 mm boyunda, yeşilimsi-beyaz veya açık sarı renkli. Meyve folikül. 635 m’ye kadar olan yüksekliklerdeki kireç taşlı kayalık yamaçları tercih eden bu tür, mayıs ve haziran aylarında çiçeklenir. Akd. El.

\section{Familya: Ericaceae (Fundagiller)}

\section{Arbutus andrachne L. (sandal ağacı)}

4-5 m boyunda kırmızı gövdeli ağaçlar veya küçük ağaçlar. Yapraklar genişçe yumurtamsı. Pedisel salgılı tüylü. Korolla ibrik şeklinde, yeşilimsi-beyaz renkli. Üzümsü meyve kırmızı veya portakal renkli, yenilebilir. Mart-mayıs aylarında çiçeklenen bu bitki, yetişme ortamı olarak deniz seviyesinden başlayarak 800 m'ye kadar olan yüksekliklerdeki makilikleri, kızılçam ormanlarını serpantin ve kireç taşlı yerleri tercih eder. ÇBFCB.

\section{Erica manipuliflora Salisb. (püren)}

Herdem yeşil, 4 m'ye kadar boylanabilen dik çalılar. Yapraklar genellikle her halkada $4^{\prime}$ lü ve iğnemsi. Korolla pembe veya beyaz renkli, çansı. Meyve kapsül. Ülkemizde Ege ve Akdeniz Bölgeleri'nde ülkemiz dışında ise Akdeniz havzasının doğu kesimlerinde yayılış gösteren bu tür, (mayıs-) temmuz-kasım aylarında çiçeklenir. Bu tür, yetişme ortamı olarak deniz seviyesinden başlayarak 1530 m'ye kadar olan yüksekliklerdeki açık alanları, makilikleri, kızılçam altlarını, kireç taşlı, serpantin ve şistli kayalıkları tercih eder. ÇBFCB.

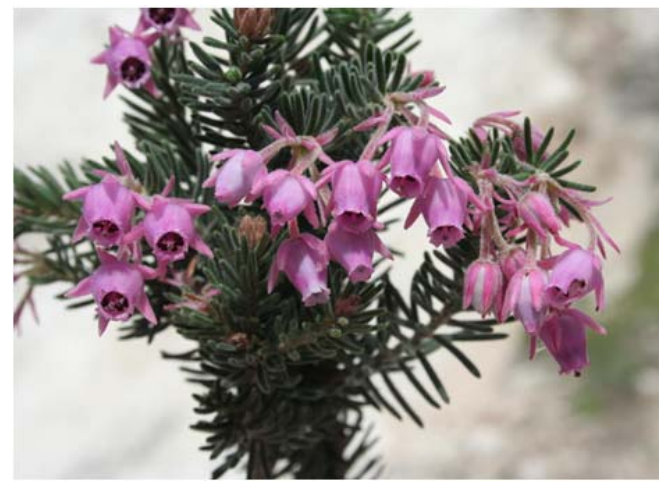

Fig. 19. Erica sicula subsp. libanotica 
Erica sicula Guss. subsp. libanotica (Barb.-Boiss.\& Barbey) P.F. Stevens (yılgun çalısı) (Fig. 19) Herdem yeşil, 60 cm'ye kadar boylanabilen dik veya sarkık çalılar. Yapraklar genellikle her halkada 4'lü ve iğnemsi. Korolla pembe renkli, ibrik şeklinde. Meyve kapsül. Bu alt tür ülkemiz dışında Kıbrıs ve Lübnan'da ülkemizde ise Kemer çevresinde çok sınırlı bir alanda yayılış göstermektedir. Yetişme ortamı olarak ise 60-500 m'ler arasındaki gölgeli kireçtaşı kayalık yamaçlarını tercih eder. Akd. El.

\section{Familya: Euphorbiaceae (Sütleğengiller)}

Euphorbia characias L. subsp. wulfenii (Hoppe ex W.D.J. Koch) Radcl.-Sm. (ulu sütleğen)

Sağlam yapılı, keçemsi tüylü çok yıllık otsu bitkiler. Çiçekli gövde iki yıllık. Gövde yaprakları şeritsiden dar eliptik-ters mızraksıya kadar değişen şekillerde. Işın yaprakları ters yumurtamsı-ters mızraksı. Çiçek durumu siyatyum. Meyve kapsül ve 3 loplu. Bu tür, deniz seviyesinden başlayarak 1000 m'ye kadar olan yüksekliklerdeki kızılçam açıklıklarında, meşe ormanlarında, kayalık kireç taşı yamaçlarında ve yol kenarlarında yetişir. Çiçeklenme zamanı ise ocak-mayıs ayında çiçeklenir. Akd. El.

\section{Euphorbia peplis L. (kıyı sütleğeni)}

Yatık gövdeli, genellikle tabanda 4-dallı, çoğunlukla morumsu, tek yıllık otsu bitkiler. Yapraklar oraksı-dikdörtgenimsi. Çiçek durumu siyatyum. Meyve kapsül ve 4-5 mm çapında. Yetişme ortamı olarak deniz seviyesinden başlayarak 900 m’ye kadar olan yüksekliklerdeki deniz kıyısı kumullarını ve tuzlu göl kenarlarını tercih eder. Çiçeklenme zamanı ise haziran-eylül aylarıdır. Akd. El.

\section{Mercurialis annua L. (parşen)}

5-50 cm boyunda, çok dallı, tek yıllık otsu bitkiler. Yapraklar yumurtamsıdan eliptik-mızraksıya kadar değişen şekillerde. Erkek çiçekler 2-9 cm boyunda. Dişi çiçekler kısa saplı. Meyve şizokarpik. Tohumlar yumurtamsı. Şubat-temmuz aylarında çiçeklenen bu tür,Yetişme ortamı olarak ise deniz seviyesinden başlayarak 2000 m’ye kadar olan yüksekliklerdeki kireçtaşı kayalıklarını, kızılçam ormanını, frigana'yı ve nemli yerleri tercih eder. ÇBFCB.

Familya: Fabaceae (Baklagiller)

\section{Anagyris foetida L. (zivircik)}

3 m'ye kadar boylanabilen kokulu çalılar. Yapraklar 3 yaprakçıklı; yaprakçıklar eliptik, tüylü. Kaliks çıngırak şeklinde. Korolla sarı renkli, standart siyah lekeli. Baklamsı meyve 7-20 cm boyunda, basık. Mart-mayıs ayında çiçeklenen bu tür, yetişme ortamı olarak deniz seviyesinden başlayarak 1000 m’ye kadar olan yüksekliklerdeki kayalık yamaçları ve yaprak döken ağaçların bulunduğu yerlerde yetişir. Akd. El.

\section{Astragalus hamosus L. (koçboynuzu)}

50 cm'ye kadar boylanabilen dik, eğik tırmanışı veya yatık gövdeli, tek yıllık otsu bitkiler. Yapraklar imparipinnat; yaprakçıklar basit tüylü, dikdörtgenimsiden ters yumurtamsıya kadar değişen şekillerde. Kaliks 6-8 mm boyunda. Korolla beyaz veya soluk sarı renkli. Baklamsı meyve orak şeklinde kıvrılmış. Mart-temmuz aylarında çiçeklenen bu tür, yetişme ortamı olarak deniz seviyesinden başlayarak 1000 m'ye kadar olan yüksekliklerdeki tarlaları ve yol kenarlarını tercih eder. ÇBFCB.

\section{Bisserula pelecinus L. (tarakyoncası)}

Yatık gövdeli veya eğik tırmanışlı tek yıllık otsu bitkiler. Yapraklar imparipinnat; yaprakçıklar dik- 
dörtgenimsiden kamamsıya kadar değişen şekillerde. Stipüller yumurtamsı. Brakteler mızraksı. Kaliks çanımsı-tüpsü. Korolla soluk leylak renkli. Baklamsı meyve $20-40 \mathrm{~mm}$ boyunda, girintili çıkıntılı. Ülkemizde Ege ve Akdeniz Bölgeleri'nde yayılış gösteren bu tür, nisan-haziran aylarında çiçeklenir. Yetişme ortamı olarak ise deniz seviyesinden başlayarak 1000 m'ye kadar olan yüksekliklerdeki tuzcul alanları ve nemli yerleri tercih etmektedir. Akd. El.

\section{Bituminaria bituminosa (L.) C.H. Stirt. (asfalt otu)}

140 cm'ye kadar boylanabilen, tüylü çok yıllık bitkiler. Yapraklar imparipinnat; yaprakçıklar şeritsi -mırraksıdan genişçe yumurtamsıya kadar değişen şekillerde. Korolla maviden menekşeye kadar değişen renklerde. Baklamsı meyve 1 tohumlu. Bu tür, yetişme ortamı olarak deniz seviyesinde 900 m’ye kadar olan yüksekliklerdeki, açık alanları ve ormanlık alanları tercih eder. Akd. El.

\section{Calicotome villosa (Poir.) Link (keçiboğan)}

3 m’ye kadar boylanabilen dikenli çalılar. Yapraklar 3 yaprakçıklı; yaprakçıklar ters yumurta biçimli. Korolla sarı renkli. Baklamsı meyve darca dikdörtgenimsi. Mart-haziran ayları arasında çiçeklenen bu tür, maki ve özellikle de garik kuşak içinde yetişir. Deniz seviyesinden 900 m’ye kadar olan yüksekliklerde yetişen bu bitki, çit yapımında ve erozyon kontrolünde kullanılmaktadır. Akd. El.

\section{Ceratonia siliqua L. (keçiboynuzu, harnup)}

10 m'ye kadar boylanabilen, genellikle bir evcikli ağaçlar. Yapraklar imparipinnat parçalı; yaprakçıklar eliptikten dairesele kadar değişir. Kaliks dökülücü. Petaller yok. Baklamsı meyve çok tohumlu, yassı ve koyu kahverengi renkli. Özellikle maki içinde ve yaprak döken ormanlarda yetişen bu tür, nisan ve mayıs aylarında çiçeklenir. Meyveleri kuruyemiş olarak kullanıldığı gibi parfümeri sanayinde ruj yapımında da kullanılır. Akd. El.

\section{Cercis siliquastrum L. subsp. siliquastrum (erguvan, yahuda ağacı, deli boynuz)}

Yaprak döken çalılar veya küçük ağaçlar. Gövde 2-10 m boyunda. Kaliks geniş çıngırak şeklinde. Korolla erguvan veya morumsu-pembe renkli. Baklamsı meyve şeritsi-dikdörtgenimsi, kızıl kahverengi renkli. Bu alt tür, yetişme ortamı olarak deniz seviyesinden başlayarak 1370 m'ye kadar olan maki ve yaprak döken ormanlarda yetişir. Akd. El.

\section{Colutea melanocalyx Boiss. \& Heldr. subsp. melanocalyx} (kara patlangaç) (Türkiye endemiği) (Fig. 20)

Yaprak döken çalılar. Yapraklar imparipinnat; yaprakçıklar eliptik. Kaliks çan şeklinde. Korolla sarı renkli. Meyve şişkin. Bu alt tür, yetişme ortamı olarak deniz seviyesinden başlayarak 1200 m'ye kadar olan kayalık yamaçları, ormanlık alanları ve çalııkları tercih eder. Çiçeklenme zamanı ise mart-mayıs aylarıdır. Akd. El.

\section{Dorycnium hirsutum (L.) Ser. (kıllı kaplanotu)}

Çok yıllık otsu bitkiler veya küçük yarı çalılar. Gövdeler 20-50 cm boyunda, yoğun dağınık tüylü. Yaprakçıklar dikdörtgenimsiters yumurtamsı. Korolla beyaz veya pembe renkli. Legümen meyve dikdörtgenimsi. Nisan-haziran aylarında çiçeklenen bu tür, yetişme ortamı olarak deniz seviyesinden başlayarak 900

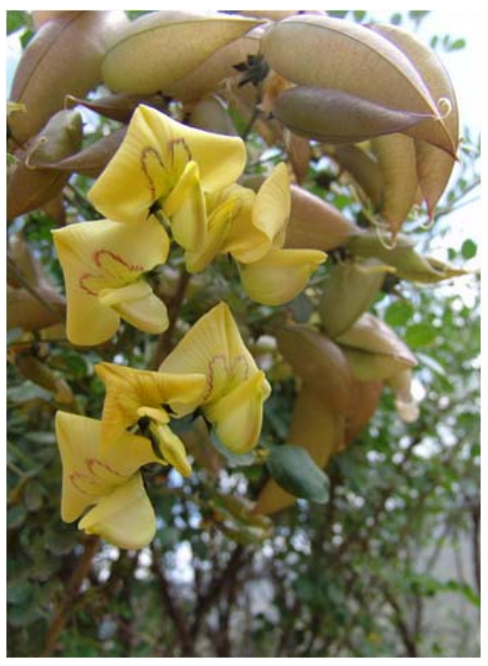

Fig. 20. Colutea melanocalyx subsp. melanocalyx m'ye kadar olan kalkerli yamaçlar, kuru tepeleri tercih eder. Akd. El. 


\section{Genista acanthoclada DC. (kertikefen)}

Dikenli çalılar. Gövde 100 cm'ye kadar boylanabilir. Yapraklar 3-yaprakçıklı; yaprakçıklar darca ters mızraksı, basık tüylü. Kaliks 2.5-5 mm boyunda. Korolla sarı renkli. Baklamsı meyve, yumurtamsı, tüylü. Ülkemizde Ege, Akdeniz Bölgeleri'nde, ülkemiz dışında ise Yunanistan ve Ege Adaları'nda yayılış gösteren bu tür, mart-mayıs aylarında çiçeklenir. Yetişme ortamı olarak ise 10800 m’ler arasındaki, kireç taşlı kayalık yamaçları, maki ve çam ormanlarını tercih eder. Akd. El.

\section{Glycyrrhiza asymmetrica Hub.-Mor. (Türk meyanı) (Antalya endemiği) (Fig. 21a-b)}

70 cm'ye kadar boylanabilen, salgılı çok yıllık otlar. Yapraklar imparipinnat parçalı; yaprakçıklar ters yumurtamsıdan dairesel kamamsıya kadar değişen şekillerde. Korolla sarı renkli. Baklamsı meyve dikdörtgenimsi, dikenli. Ülkemize özgü olan bu Türk meyanı sadece Antalya'da yetişir. Mayıs-temmuz aylarında çiçeklenen bu tür, yetişme ortamı olarak makilik alanlı ve kızılçam ormanlarını tercih eder. Akd. El.

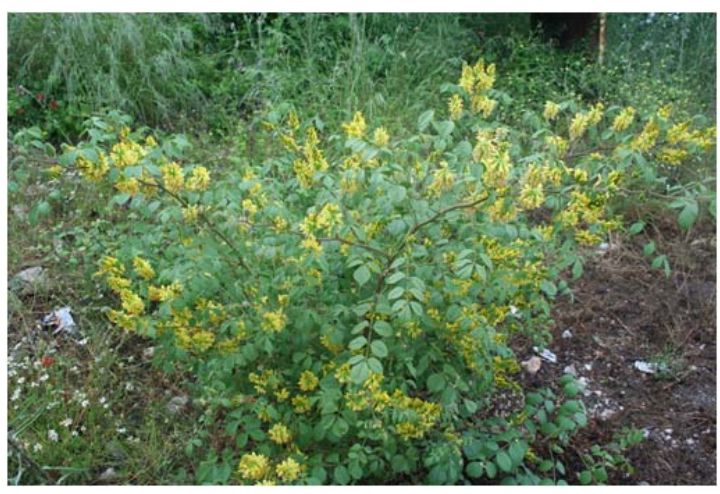

Fig. 21a. Glycyrrhiza asymmetrica

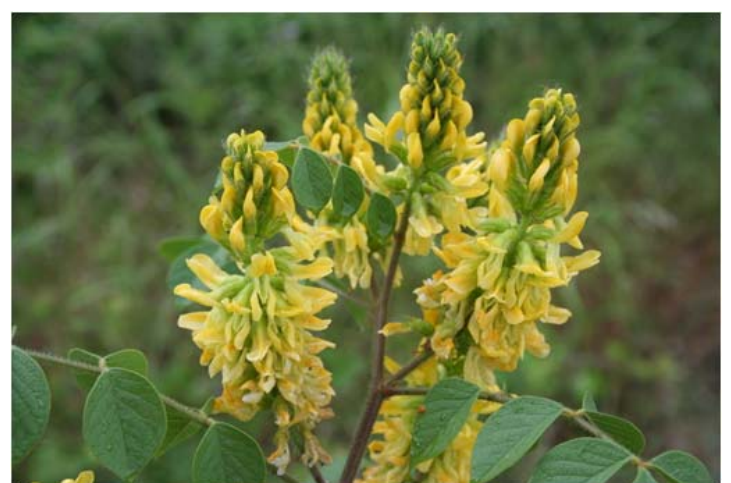

Fig. 21b. Glycyrrhiza asymmetrica'nın Çiçeklerinin Yakın Görünüşü

Glycyrhiza flavescens Boiss. subsp. antalyensis Sümbül, Ö. Tufan, O. D. Düşen \& Göktürk (Antalya meyanı) (Olimpos-Beydağları Milli Parkı endemiği)

Gelişmiş depo köke sahip çok yıllık bitkiler. Gövde 30-100 cm, çıplak kırmızı veya yeşil renkli. Yapraklar 6-8 parçalı; yaprakçıklar eliptik. Korolla sarı renkli. Baklamsı meyve 30-45 mm boyunda ve çıplak. 2003 yılında bilim dünyasına tanıtılan bu alt tür, nisan-mayıs aylarında çiçeklenir. Ülkemize özgü olan bu alt tür, sadece Olimpos-Beydağları Milli Parkı'nda yetişir. Yetişme ortamı olarak 10200 m’ler arasındaki, kızılçam altı ve açıklıklarını, makiyi ve serpantin alanları tercih eder. Akd. El.

\section{Hippocrepis emerus (L.) Lassen subsp. emeroides (Boiss. et Spruner) Lassen (tel gevrecik)}

2.5 m’ye kadar boylanabilen çalılar. Yapraklar pinnat parçalı; yaprakçıklar kamamsı. Korolla sarı renkli. Boğumlu meyve 5-11 mm boyunda. Bu alt tür, yetişme ortamı olarak deniz seviyesinden başlayarak 1300 m’ye kadar olan çalıııklar arasında yetişir. Çiçeklenme zamanı ise mart-mayıs aylarıdır. ÇBFCB.

\section{Lathyrus belinensis Maxted \& Goyder (belen burçağı) (Olimpos-Beydağları Milli Parkı endemiği)} (Fig. 22)

Tırmanıcı veya sürünücü 50-200 cm boyunda, kanatlı, tek yıllık bitkiler. Yapraklar bir parçalı yaprakçıklı ve çok parçalı tendril ile sonlanır; yaprakçıklar yumurtamsı, eliptik veya ters yumurtamsı-eliptik. Kaliks 7-9 mm boyunda. Standart 20-26 mm boyunda, turuncu-sarı renkli, 
belirgin kırmızı çizgili. Legümen meyve dikdörtgenimsi. Olimpos-Beydağları Milli Parkı́na özgü olan bu tür, yetişme ortamı olarak 330-560 m’ler arasındaki kireç taşlı kayalık tepelikleri ve kültür tarlaların kenarlarını tercih eder. Akd. El.

Lathyrus phaselitanus Hub.-Mor. \& Davis (Faselis burçağı) (Olimpos-Beydağları Milli Parkı endemiği) (Fig. 23)

Narin yapılı, gösterişli, tırmanıcı tek yıllık otsu bitkiler. Gövde 1 m'ye kadar boylanabilir, çıplak. Yaprakçıklar şeritsi-eliptik. Korolla menekşe renkli. Legümen meyve şeritsi dikdörtgenimsi. Ülkemize özgü olan bu tür, sadece Olimpos-Beydağları Milli Parkı'nda yetişir. Mayıs-haziran aylarında çiçeklenen bu burçak türü, yetişme ortamı olarak yaklaşık 70 m’ler civarındaki makilik alanları tercih eder. Akd. El.

\section{Medicago marina L. (sahil yoncası)}

Yatık gövdeli, yünsü-keçemsi tüylü çok yıllık otsu bitkiler. Yaprakçıklar ters yumurtamsı-kamamsı. Korolla sarı renkli. Meyve diskioid veya silindirik, kısa ve ince dikenli. Şubat-haziran aylarında çiçeklenen bu tür, yetişme ortamı olarak deniz kenarlarındaki kumulları tercih eder. ÇBFCB.

\section{Medicago orbicularis (L.) Bartal. (paralık)}

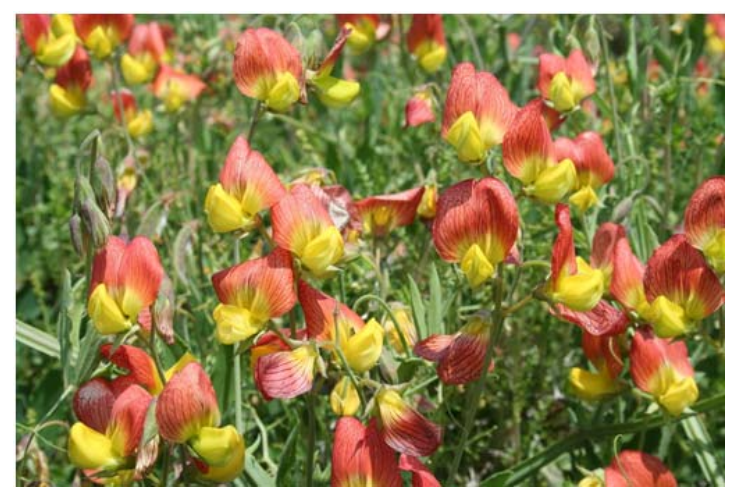

Fig. 22. Lathyrus belinensis

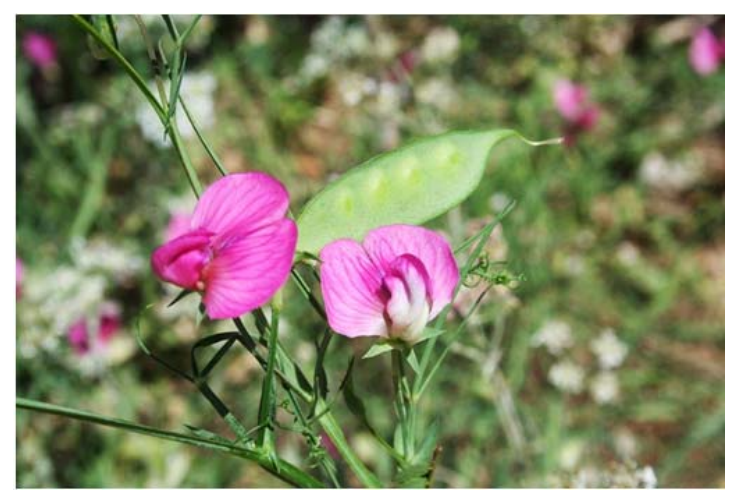

Fig. 23. Lathyrus phaselitanus

40 cm'ye kadar boylanabilen tek yıllık otlar. Yaprakçıklar ters yumurtamsı veya keskin kamamsı. Meyve halka şeklinde kıvrımış, disk şeklinde. Bu tür, yetişme ortamı olarak yoğun toprakları, kayalık yamaçları, kültür alanlarını tercih eder. ÇBFCB.

\section{Ononis natrix L. subp. hispanica (L. f.) Cout. (ölemez)}

Yapışkan tüylü, küçük çalılar. Gövde dik, yükselici, 15-100 cm boyunda. Yapraklarçoğunlukla 3yaprakçıklı; yaprakçıklar yarı dairesel, yumurtamsı, dikdörtgenimsi veya şeritsi, dişi kenarlı. Kaliks çan şeklinde. Korolla sarı renkli; standart kırmızı çizgili. İlk kez İspanya'dan toplanarak bilim dünyasına tanıtılan bu alt tür, yetişme ortamı olarak deniz kumullarını tercih eder ve mayıs-ağustos aylarında çiçeklenir. Akd. El.

\section{Securigera parviflora (Desv.) Lassen (bahçetacı)}

40 cm'ye kadar boylanabilen tek yıllık bitkiler. Yaprakçıklar kamamsı. Korolla sarı, beyaz, pembe, leylak renkli. Boğumlu meyve 3-7 cm boyunda ve yay gibi kıvrık. Ülkemizde Ege ve Akdeniz Bölgeleri'nde yayılış gösteren bu tür, mart-mayıs aylarında çiçeklenir. Yetişme ortamı olarak ise deniz seviyesinden başlayarak 1200 m'ye kadar olan tahrip edilmiş alanları tercih eder. Akd. El.

Spartium junceum L. (katırtırnağı) (Fig. 24a-b)

4 m’ye kadar boylanabilen çalılar. Yapraklar küçük, basit, dökülücü, dar eliptik. Korolla sarı renkli, kokulu. Baklamsı meyve ince, uzun, 12-20 tohumlu. Yetişme ortamı olarak deniz seviyesinden 600 m'ye kadar olan yüksekliklerdeki makilik alanları ve denize yakın kayalıkları tercih eder. To- 


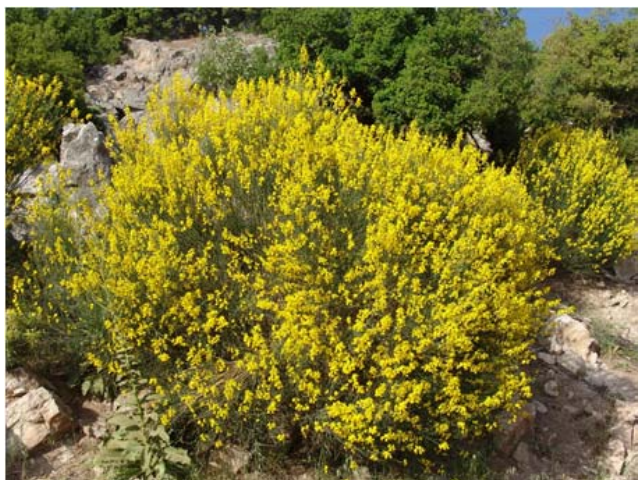

Fig. 24a. Spartium junceum

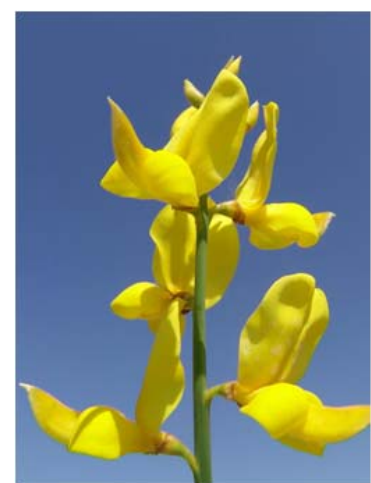

Fig. 24b. Spartium junceum Çiçeklerinin Yakın Görünüşü

humları zehirli olan katırtırnağı mayıs-temmuz aylarında çiçeklenir. Akd. El.

Trifolium campestre Schreb. subsp. campestre var. campestre (üçgül)

Yükselici veya sürünücü tek yıllık otsu bitkiler. Gövde $10-30 \mathrm{~cm}$ boyunda. Yaprakçıklar yumurtamsıdan ters yumurtamsıya kadar değişen şekillerde. Çiçek durumu küresel, çok çiçekli. Korolla soluk veya parlak sarı renkli. Meyve baklamsı tipte. Ülkemizin hemen hemen tüm bölgelerinde yayılış gösteren bu varyete, yetişme ortamı olarak deniz seviyesinden 2200 m'ye kadar olan yüksekliklerdeki tarlaları ve nemli alanları tercih eder. Şubat-eylül aylarında çiçeklenir. ÇBFCB.

\section{Trifolium stellatum L. var. stellatum (yıldız yonca)}

Dik veya eğik tırmanışlı tek yılık otsu bitkiler. Gövde 10-20 cm boyunda. Yaprakçıklar ters kalpsi. Kaliks çansı. Korolla beyaz veya pembe renkli. Nisan ayında çiçeklenen bu varyete, yetişme ortamı olarak deniz seviyesinden 900 m’ye kadar olan yüksekliklerdeki yol kenarlarını, tarlaları ve çalılık alanları tercih eder. ÇBFCB.

\section{Trigonella coerulescens (M. Bieb.) Halácsy subsp. kemerensis Göktürk (kum çemenotu)}

\section{(Olimpos-Beydağları Milli Parkı endemiği)}

20 cm'ye kadar boylanabilen yatık gövdeli, keçemsi tüylü, tek yıllık otsu bitkiler. Yaprakçıklar ters yumurtamsı ve keçemsi tüylü. Kaliks tüpsü, $5 \mathrm{~mm}$ boyunda. Korolla mavi renkli. Olimpos-Beydağları Milli Parkı'na özgü bir bitkidir. Bu alt tür, yetişme ortamı olarak plaj kumullarını tercih etmekte olup, mart ve nisan aylarında çiçek açar. Akd. El.

\section{Tripodion tetraphyllum (L.) Fourr. (kumtırfılı)}

Yatık gövdeli, tüylü tek yıllık otsu bitkiler. Yapraklar imparipinnat; uçtaki yaprakçık ters yumurtamsı. Kaliks çiçekli halde şişkin, tüylü. Korolla sarı veya krem renkli. Baklamsı meyve 2 tohumlu. Bu tür, yetişme ortamı olarak deniz seviyesinden başlayarak 1000 m’ye kadar olan yüksekliklerdeki kayalık yamaçları, tarlaları tercih eder. Çiçeklenme zamanı ise nisan ve mayıs aylarıdır. Akd. El.

\section{Familya: Fagaceae (Kayıngiller)}

\section{Quercus coccifera L. (kermes meşesi)}

Herdem yeşil çalılar veya nadiren 10 m’ye kadar boylanabilen ağaçlar. Yapraklar genişçe yumurtamsıdan dikdörtgenimsi-yumurtamsıya kadar değişen şekillerde, düz veya keskin testere dişli dikenli kenarlı. Pistillat çiçekler tek veya 2'den çok. Meyve fincan şeklinde kupula tarafından sarılmış fındık. Eylül-kasım aylarında meyve veren tür, makinin baskın bir üyesidir ve deniz sevi- 
yesinden 1700 m'ye kadar olan yüksekliklerde yayılış gösterir. Akd. El.

Quercus infectoria Oliv. subsp. veneris (A. Kern) Meikle (zindiyen) (Fig. 25)

Yaprak döken veya herdem yeşil küçük ağaçlar veya çalılar. Yapraklar derimsi, yumurtamsıdan darca dikdörtgenimsiye kadar değişen şekillerde. Meyve fincan şeklinde kupula tarafından sarılmış fındık. Bu alt tür, yetişme ortamı olarak deniz seviyesinden 1850 m'ye kadar olan yüksekliklerdeki maki ve karışık ormanları tercih etmektedir. ÇBFCB.

\section{Familya: Geraniaceae (Turnagagasıgiller)}

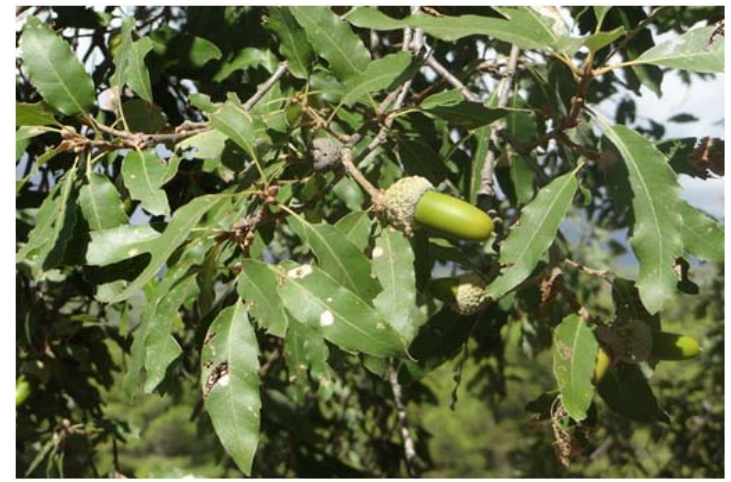

Fig. 25. Quercus infectoria subsp. veneris

\section{Erodium cicutarium (L.) L'Hérit subsp. cicutarium (iğnelik)}

40 cm'ye kadar boylanabilen tek yıllık otsu bitkiler. Taban yapraklar pinnat parçalı; yaprakçıklar yumurtamsı-dikdörtgenimsi. Sepaller 4-5 mm boyunda. Petaller pembe veya leylak renkli. Meyve uzun gagalı (septifragal ), 2.5-3.5 cm boyunda. Ülkemizde oldukça geniş bir yayılış alanına sahip olan bu bitki, 1200 m'ye kadar olan yüksekliklerdeki, tarlaları, çayırlıkları ve maki açıklıklarını yetişir. Çiçeklenme zamanı ise mart-mayıs aylarıdır. ÇBFCB.

\section{Geranium Iucidum L. (dakkaotu)}

6-30 cm boyunda, çoğunlukla kırmızı gövdeli tek yıllık otsu bitkiler. Yapraklar palmat parçalı. Petaller parlak pembe veya nadiren beyaz renkli. Meyve merikarp. Mart-mayıs aylarında çiçeklenen bu tür, yetişme ortamı olarak deniz seviyesinden 1700 m'ye kadar olan yüksekliklerdeki gölgeli yerleri ve kireç taşı kayalıkları tercih eder. ÇBFCB.

Familya: Lamiaceae (Ballıbabagiller)

\section{Ajuga orientalis L. (dağmayasılı)}

Gri uzun yünsü tüylü, kısa rizomlu çok yıllık bitkiler. Gövde sağlam, dik veya eğik tırmanışlı, 6-30 $\mathrm{cm}$ boyunda. Alt yapraklar dikdörtgenimsi-eliptik. Çiçek durumları sık. Korolla aynı anda mavi ve krem renkli. Fındıksı meyve buruşuk. Nisan-temmuz aylarında çiçeklenen bu dağmayasıılı, yetişme ortamı olarak deniz seviyesinden 3130 m'ye kadar olan yüksekliklerdeki ormanları, çalılıkları, kayalık yamaçları ve otlaklıkları tercih eder. ÇBFCB.

\section{Clinopodium pamphylicum (Boiss. \& Heldr.)} Govaerts subsp. davisii (Contandr. \& Quezel) Govaerts (kemer fesleğeni) (OlimposBeydağları Milli Parkı endemiği) (Fig. 26)

Narin yapılı, 20 cm'ye kadar boylanabilen, kısa tüylü çok yıllık otsu bitkiler. Yapraklar üçgenimsi tabanda kesik veya yarı kalpsi veya geniş̧̧e yumurtamsı, tüylü. Çiçek durumları (2-)5-15 çiçekli. Korolla leylaktan pembeye kadar değişen renklerde. Meyve fındıksı. Sadece Olimpos-Beydağları

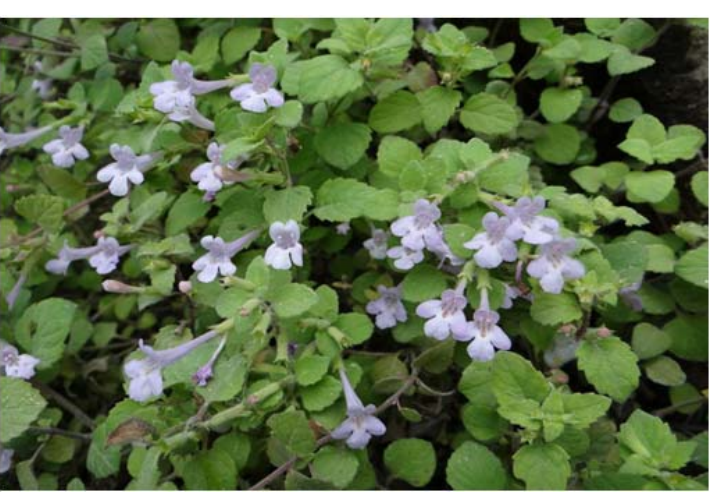

Fig. 26. Clinopodium pamphylicum subsp. davisii Milli Parkı'nda yetişen bu alt tür, mart-mayıs 
(-ağustos) ayında çiçeklenir. Yetişme ortamı olarak ise 50-500 m’ler arasındaki yüksekliklerdeki, kireç taşı kayalıklarını ve özellikle kızılçam orman altlarını tercih eder. Akd. El.

\section{Dorystoechas hastata Boiss. \& Heldr. ex Benth.(şalba/devrenkekiği) (Antalya endemiği)}

Aromatik, 40-100 cm boyunda, odunlu çalılar. Yapraklar basit, mızraksı-zıpkınsı. Çiçek durumu 6$17 \mathrm{~cm}$ boyunda. Korolla beyaz renkli. Meyve Fındıksı. Buzul devirlerinden kalma olan bu relikt endemik tür, sadece Antalya il sınırları içinde yetişmektedir. Yetişme ortamı olarak ise 100-2000 m'ler arasındaki, çam, servi ormanlarını ve makilik alanları tercih eder. Çiçeklenme zamanı mayıs-temmuz aylarıdır. Akd. El.

\section{Lamium amplexicaule L. (baltutan)}

$45 \mathrm{~cm}$ 'ye kadar boylanabilen tek yıllık otsu bitkiler. Yapraklar yumurtamsı-böbreksi veya yarı dairesel. Çiçek durumları 4-10 çiçekli. Kaliks tüpsü, 4-8.5 mm boyunda. Korolla mor, pembe renkli. Fındıksı meyveler koyu kahverengi. Ülkemizin hemen hemen tüm bölgelerinde yayılış gösteren bu tür, şubat-kasım aylarında çiçek açar. Yetişme ortamı olarak 3-2270 m'ler arasındaki tepelikleri, yol kenarlarını, açık stebi ve nemli alanları tercih eder. ÇBFCB.

\section{Lavandula stoechas L. subsp. stoechas (karabaş) (Fig. 27a-b)}

Keçemsi tüylü, $45 \mathrm{~cm}$ veya daha fazla boylanabilen çalılar. Üst yapraklar mızraksı, eliptik veya darca eliptik. Çiçek durumları yoğun 6-10 çiçekli. Kaliks 4-6 mm boyunda. Korolla siyahımsı-mor renkli. Fındıksı meyveler çıplak ve düz. Nisan-haziran aylarında çiçeklenen bu karabaş otu, yetişme ortamı olarak deniz seviyesinden 700 m'ye kadar olan yüksekliklerdeki kızılçam ormanı açıkIıklarını, makilik alanları, friganayı kum tepelerini, yol kenarlarını ve kayalık yamaçları tercih eder. Akd. El.

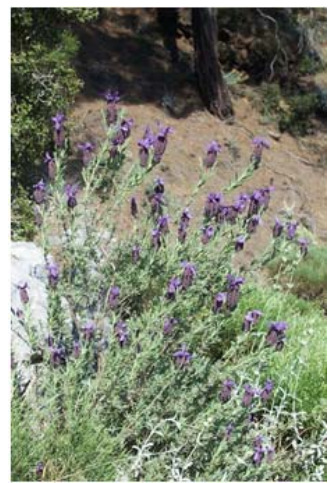

Fig. 27a. Lavandula stoechas subsp. stoechas

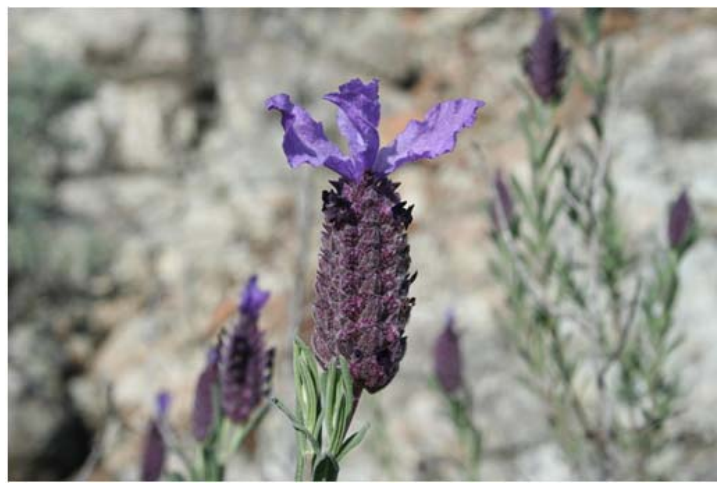

Fig. 27b. Lavandula stoechas subsp. stoechas Çiçeklerinin Yakın Görünüşü

Micromeria myrtifolia Boiss. \& Hohen. (boğumluçay)

Dik, yarı çalımsı, 20-40 cm boyunda. Gövde yaprakları yumurtamsıdan eliptiğe kadar değişen şekillerde. Kaliks silindirik. Korolla mor veya pembe renkli. Mayıs-temmuz aylarında çiçeklenen bu tür, yetişme ortamı olarak, deniz seviyesinden 700 m’ye kadar olan yüksekliklerdeki kayalık yamaç ve yarıklarını, kızılçam ormanı açıklıklarını, makilik alanları ve friganayı tercih eder. ÇBFCB.

Origanum onites L. (bilyalı kekik) (Fig. 28)

Sert tüylü, yarı çalı, 65 cm'ye kadar boylanabilen bitkiler. Yapraklar kalpsi, yumurtamsı veya eliptik. Kaliks 2-3 mm boyunda. Korolla beyaz renkli. Ülkemiz dışında Yunanistan, Sicilya ve Ege Adaları'nda yayılış gösteren bu tür, nisan-ağustos aylarında çiçeklenir. Bu tür, yetişme ortamı olarak 
deniz seviyesinden 700 m’ye kadar olan yüksekliklerdeki kayalık tepelikleri, kayalık yamaçları ve kireçli alanları tercih eder. ÇBFCB.

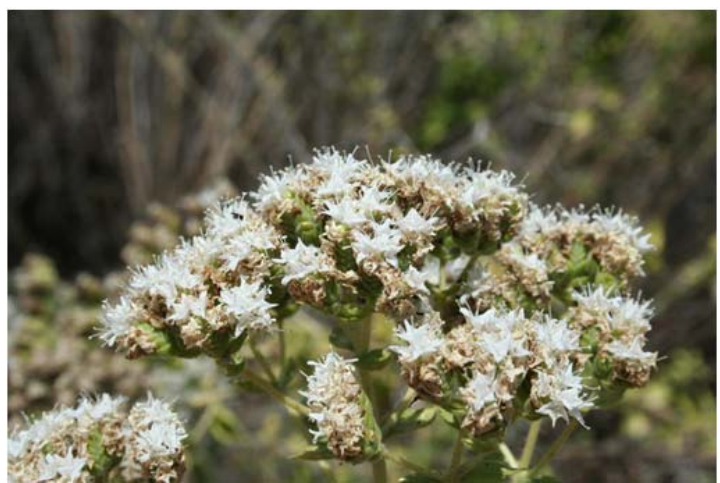

Fig. 28. Origanum onites

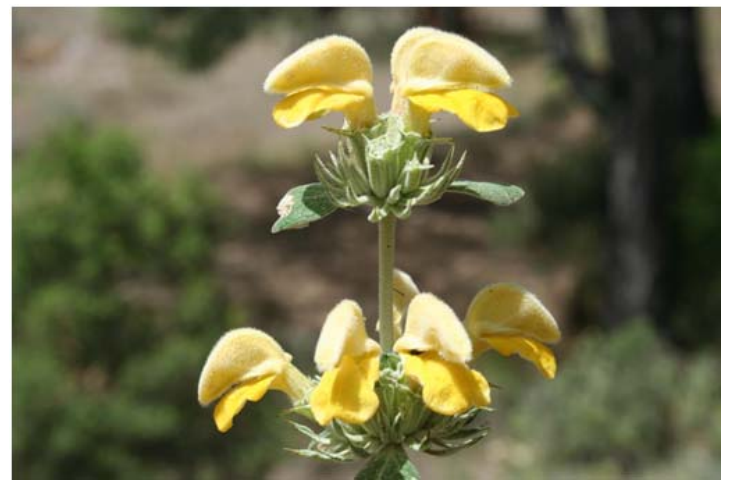

Fig. 29. Phlomis chimerae

Phlomis chimerae Boissieu (Türkmen çırası) (Olimpos-Beydağları Milli Parkı endemiği) (Fig. 29)

50 cm'ye kadar boylanabilen bodur çalılar. Yapraklar üst kısımda küçük yıldızsı tüylü, alt kısımda ise beyaz keçemsi tüylü. Çiçek durumları 6-12 çiçekli. Kaliks 15-20 mm boyunda. Korolla sarı renkli. Fındıksı meyve çıplak. Nisan-ağustos aylarında çiçeklenen bu tür Olimpos-Beydağları Milli Parkı'na özgüdür. Yetişme ortamı olarak ise deniz seviyesinden 150 m’ye kadar olan makilikleri, kızılçam ormanını ve kayalık yamaçları tercih eder. Akd. El.

\section{Phlomis grandiflora H. S. Thompson subsp. grandiflora (bahargülü)}

2 m'ye kadar boylanabilen çalılar.Yapraklar üst kısımda yıldızsı, alt kısımda ise beyaz keçemsi tüylü; alt yapraklar yumurtamsıdan dikdörtgenimsiye kadar değişen şekillerde; çiçek yaprakları ise dikdörtgenimsi. Çiçek durumları tek kafalı ve çok çiçekli. Kaliks 13-17 mm boyunda. Korolla sarı renkli. Fındıksı meyve çıplak. Bu tür, yetişme ortamı olarak (20-) 600-1220 m’ye kadar yüksekliklerdeki kızıç̧am ormanlarını, meşe çalılıklarını, kireç taşlı yamaçları ve kayalıkları tercih eder. Çiçeklenme zamanı ise mayıs-ağustos aylarıdır. Akd. El.

\section{Prasium majus L. (çalıbaba)}

1 m'ye kadar boylanabilen çalılar, nadiren otsular. Yapraklar yumurtamsı veya yumurtamsımızraksı. Kaliks çıplak. Korolla beyaz, nadiren krem renkli. Fındıksı meyve siyah. Ege ve Akdeniz Bölgeleri'nde yayılış gösteren bu tür, mart-mayıs aylarında çiçeklenir. Yetişme ortamı olarak deniz seviyesinden 180 m'ye kadar olan yüksekliklerdeki makilikleri, çam altlarını, yol kenarlarını ve yamaçları tercih eder. Akd. El.

\section{Prunella vulgaris L. (gelinciklemeotu)}

Dik veya eğik tırmanışlı, 6-40 cm boyunda çok yıllık otlar. Yapraklar yumurtamsıdan dikdörtgenimsi mızraksıya kadar değişen şekillerde. Kaliks tüpsü, çan şeklinde. Korolla koyu menekşe veya lavanta mavisi. Fındıksı meyve yumurtamsı veya eliptik. Mayıs-eylül aylarında çiçeklenen bu tür, yetişme ortamı olarak deniz seviyesinden 2900 m’ye kadar olan yüksekliklerdeki tarlaları, ormanlık alanları ve nemli yerleri tercih eder. ÇBFCB.

Salvia fruticosa Mill. (adaçayı) (Fig. 30)

Çok dallı, 1 m'ye kadar boylanabilen çalılar. Yapraklar basit veya 3 loplu, yumurtamsı-dikdörtgenimsi. Çiçek durumları 2-8 çiçekli. Kaliks tüpsü-çansı, mor renkli. Korolla leylak veya beyazımsı renkli. Fındıksı meyve ters yumurtamsı-dairesel. Ülkemizde Marmara, Ege ve Akdeniz Bölgele- 
ri'nde çiçeklenen bu tür, mart-temmuz aylarında çiçeklenir. Yetişme ortamı olarak ise deniz seviyesinden 700 m'ye kadar olan yüksekliklerdeki makilikleri, kireç taşı kayalıklarını tercih eder. Akd. El.

\section{Salvia tomentosa Miller (şalba)}

Çok yıllık, küme şeklinde yarı çalımsı otsu bitkiler. Gövde 1 m'ye kadar çıkar, üst kııımda dallı. Yapraklar basit, darca dikdörtgenimsiden yumurtamsıya kadar değişen şekillerde. Çiçek durumları 4-10 çiçekli. Kaliks tüpsü. Korolla leylak, mor

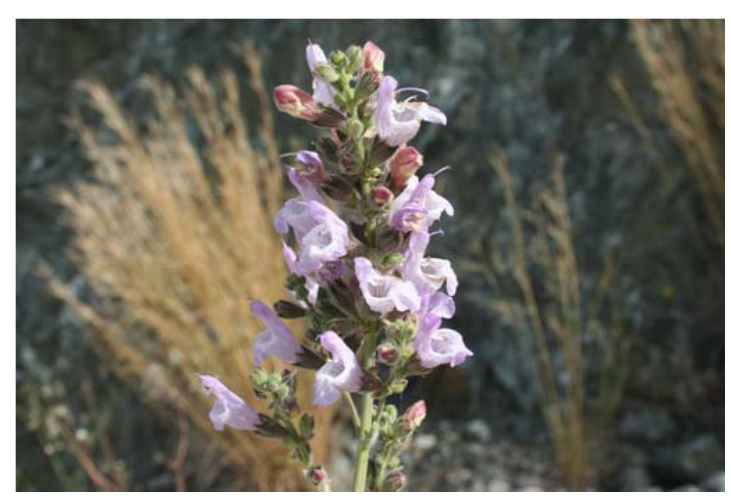

Fig. 30. Salvia fruticosa veya beyaz renkli. Meyve fındıksı. Nisan-eylül aylarında çiçeklenen bu şalba, yetişme ortamı olarak 90-2000 m’ler arasındaki çam ve meşe ormanlarını, makilikleri ve kireç taşlı kayalık yamaçları tercih eder. Akd. El.

\section{Salvia viridis L. (zarif şalba)}

Basit veya dallı gövdeli, 7-45 cm boyunda tek yıllık otsu bitkiler. Yapraklar basit, dikdörtgenimsiyumurtamsı. Çiçek durumları 4-6 çiçekli. Kaliks tüpsü. Korolla leylak-mor veya beyaz renkli. Meyve fındıksı. Ülkemizde oldukça geniş bir yayılış alanına sahip olan bu tür, ülkemiz dışında ise diğer Akdeniz ülkelerinde yayılış gösterir. Mart-temmuz aylarında çiçeklenen bu zarif şalba, yetişme ortamı olarak deniz seviyesinden 1300 m’ye kadar olan yüksekliklerdeki kayalık yamaçları, makilikleri, tarlaları ve nemli alanları tercih eder. Akd. El.

\section{Satureja thymbra L. (halilibrahim zahteri)}

Çok dallı, 20-40 cm boyunda çalılar. Yapraklar şeritsiden ters yumurtamsı-kaşıksıya kadar değişen şekillerde. Çiçek durumları çok çiçekli. Kaliks 4-6 mm boyunda. Korolla leylak veya mor renkli. Fındıksı meyve dikdörtgenimsi. Yetişme ortamı olarak deniz seviyesinden 400 m'ye kadar olan yüksekliklerdeki kuru çalıııları ve özellikle kalkerli friganayı tercih eder. Çiçeklenme zamanı ise nisan-haziran aylarıdır. Akd. El.

\section{Sideritis condensata Boiss. \& Heldr. (kozalı kekik) (Türkiye endemiği)}

1 m’ye kadar boylanabilen, beyaz-ipeksi tüylü çok yıllık bitkiler. Gövde yaprakları dikdörtgenimsieliptik veya şeritsi-dikdörtgenimsi. Çiçek durumları 6 çiçekli. Kaliks 8.5-10 mm boyunda. Korolla sarı renkli. Fındıksı meyve yumurtamsı. Antalya ve Isparta illerine özgü olan bu adaçayı türü, mayıs-temmuz aylarında çiçeklenir. Yetişme ortamı olarak ise deniz seviyesinden 1600 m'ye kadar olan yüksekliklerdeki çam ormanlarını, frigana ve yol kenarlarını tercih eder. Akd. El.

Sideritis lycia Boiss. \& Heldr. (kemer çayı) (Olimpos-Beydağları Milli Parkı endemiği) (Fig. 31)

Alt kısımda yoğun basık beyaz keçemsi tüylü, 20$40 \mathrm{~cm}$ boyunda çok yıllık otsu bitkiler. Gövde yaprakları ters mızraksı. Kaliks 9-12 mm boyunda. Korolla sarı renkli. Fındıksı meyve yumurtamsı. Bu tür, Olimpos-Beydağları Milli Parkı'na özgü olup, mayıs-temmuz aylarında çiçeklenir. Yetişme or-

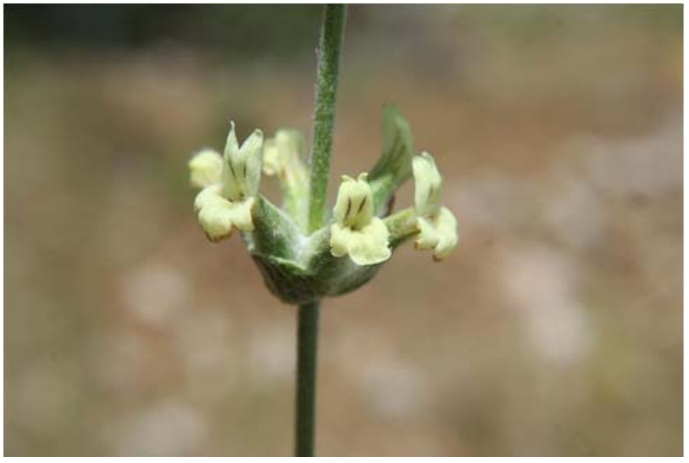

Fig. 31. Sideritis lycia 
tamı olarak ise deniz seviyesinden 80 m'ye kadar olan yüksekliklerdeki kayalıkları kızılçam ormanlarını ve makilikleri tercih eder. Akd. El.

\section{Stachys bombycina Boiss. (arı çayçesi)}

Yarı çalımsı, 30-50 cm boyunda, yoğun yünsü tüylü çok yıllık bitkiler. Alt gövde yaprakları yumurtamsıdan yumurtamsı-mızraksıya kadar değişen şekillerde. Çiçek durumları 8-12 çiçekli. Kaliks 8$11 \mathrm{~mm}$ boyunda. Korolla mor veya soluk pembe renkli. Fındıksı meyve ters yumurtamsı. Bu tür yetişme ortamı olarak 10-250 m’ler arasındaki kireç taşı kayalıklarını ve kızılçam ormanlarını tercih eder. Çiçeklenme zamanı ise mayıs-haziran aylarıdır. Akd. El.

\section{Stachys sericantha P. H. Davis (dikenli çay) (Olimpos-Beydağları Milli Parkı endemiği) (Fig. 32)}

Taban kısmı odunlu çok yıllık otsu bitkiler. Çiçekli gövde $35-70 \mathrm{~cm}$ boyunda, seyrek tüylü. Gövde yaprakları dikdörtgenimsi-mızraksı. Çiçek durumları 2-6 çiçekli. Kaliks 9-10 mm boyunda, meyveli halde kıvrık. Korolla mor-pembe renkli. Fındıksı meyve ters yumurtamsı. Olimpos-Beydağları Milli Parkı'na özgü olan bu tür, haziran ve temmuz aylarında çiçeklenir. Yetişme ortamı olarak ise 20-1300 m'ye kadar olan kireçtaşı kayalık yamaçlarını ve kızılçam ormanlarını tercih eder. Akd. El.

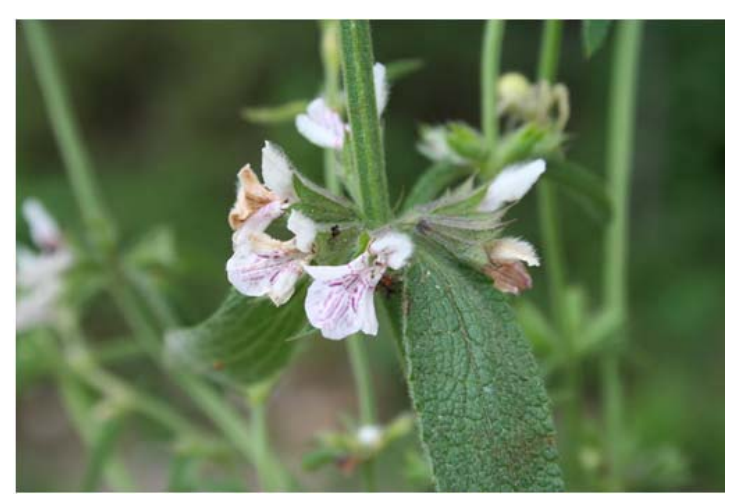

Fig. 32. Stachys sericantha

\section{Teucrium polium L. subsp. polium (acıyavşan)}

Odunsu-otsu çok yıllık bitkiler. Gövde dik veya yatık, 10-40 cm boyunda. Yapraklar dikdörtgenimsi, ters yumurtamsı veya şeritsi. Kaliks 3-5 mm boyunda. Korolla beyazımsı renkli. Fındıksı meyve $2 \mathrm{~mm}$ boyunda. Bu alt tür, yetişme ortamı olarak deniz seviyesinden 2050 m'ye kadar olan yüksekliklerdeki kuru yerleri, meşe çalııklarını, kayalık yamaçları, stebi ve tarla kenarlarını tercih etmekte olup, haziran-eylül aylarında çiçek açmaktadır. ÇBFCB.

\section{Thymbra capitata (L.) Cav. (acıkekik)}

Bodur, 20-50 (-150) cm boyunda, sert yapılı çalılar. Yapraklar sapsız, şeritsi. Kaliks 4-5 mm boyunda. Korolla mor pembe renkli. Ülkemizde Ege ve Akdeniz kıyılarındaki maki açıklıklarında ve frigana'da yetişen bu tür, mayıs-temmuz aylarında çiçeklenir. Akd. El.

\section{Vitex agnus-castus L. (hayit)}

1-3 m boyunda, çok dallı çalılar veya küçük ağaçlar. Yapraklar parmaksı; yaprakçıklar alt kısımda beyaz keçemsi tüylü. Çiçek durumu oldukça yoğun kimöz. Kaliks çan şeklinde. Korolla huni biçimli. Eriksi meyve küresel, siyah veya kırmızımsı. Ülkemizde Karadeniz, Ege, Marmara ve Akdeniz Bölgeleri'nde yayılış gösteren bu tür, haziran-eylül aylarında çiçeklenir. Yetişme ortamı olarak ise deniz seviyesinden 750 m'ye kadar olan yüksekliklerdeki çoğunlukla kumlu ve alüvyonal toprakları, deniz kenarındaki kayalık alanları ve kireç taşlı kayalık yamaçları tercih eder. Akd. El.

Familya: Lauraceae (Defnegiller)

\section{Laurus nobilis L. (defne, tehnel)}

Aromatik, herdem yeşil ağaçlar veya çalılar. Gövde 15 m’ye kadar boylanır. Yapraklar dar dikdörtgenimsi-mızraksıdan genişçe yumurtamsıya kadar değişir. Erkek çiçekler 12 stamenli. Dişi çiçekler 4 staminodlu. Üzümsü meyve 1 tohumlu, küresel-elipsoid ve siyah renkli. Bu tür, yetiş- 
me ortamı olarak deniz seviyesinden 1200 m’ye kadar olan yüksekliklerdeki makilikleri, kızılçam ormanlarını, kayalık yamaçları ve eski kaleleri tercih eder. Çiçeklenme zamanı ise mart-mayıs aylarıdır. Akd. El.

\section{Familya: Malvaceae (Ebegümecigiller)}

Alcea biennis Winterl (fatmaanagülü)

2 m'ye kadar boylanabilen çok yıllık bitkiler. Yapraklar kalın basitten 5-7 lobluya kadar değişen şekillerde. Petaller beyaz, pembe veya leylak renkli, tabanda sarımsı, 40-50 mm. Merikarp meyve kanatı. Ülkemiz dışında Macaristan ve Balkan ülkelerinde yayııış gösteren bu tür, yetişme ortamı olarak 300-1500 m'ler arasındaki yol kenarlarını, tarlaları ve stebi tercih eder. Çiçeklenme zamanı ise haziran-ekim aylarıdır. ÇBFCB.

\section{Lavatera punctata All. (saracak)}

Tek yıllık otsu bitkiler. Gövde hemen hemen dik, yıldızsı tüylü. Yapraklar 3-5 loplu, yıldızsı tüylü. Epikaliks segmentleri 3 adet, tabanda birleşik. Petaller kırmızımsı-menekşe renkli, 25-35 mm. Meyve merikarp. Mayıs-eylül aylarında çiçeklenen bu tür, 1200 m'ye kadar olan yüksekliklerdeki, deniz kıyılarını, tarlaları, yamaçları ve makilik alanları tercih eder. ÇBFCB.

\section{Malva sylvestris L. (ebegümeci)}

Dik veya eğik tırmanışlı, iki veya çok yıllık otsu bitkiler. Yapraklar hemen hemen dairesel, hafif 57 loplu. Epikaliks segmentleri 2 (-3) adet. Sepaller genişçe mızraksı. Petaller 18-25 mm, leylaktan pembeye kadar değişen renklerde. Merikarp meyve çıplak veya tüylü. Bu tür, yetişme ortamı olarak deniz seviyesinden 500 m'ye kadar olan yüksekliklerdeki çalılıkları, tarlaları ve açık alanları tercih eder. Çiçeklenme zamanı ise mayıs-ekim aylarıdır. ÇBFCB.

\section{Familya: Myrtaceae (Mersingiller)}

\section{Myrtus communis L. subsp. communis (mersin) (Fig. 33)}

1-5 m boyunda çalılar. Yapraklar yumurtamsımızraksı, aromatik. Çiçekler beyaz renkli. Meyve yarıküresel-geniş elipsoid, olgunlaşınca mavimsi -siyahsı renkli. Yetişme ortamı olarak 500 m'ye kadar olan yüksekliklerdeki kayalık yamaçları, çam ormanlarını ve makilik alanları tercih etmekte olan bu alt tür, haziran-eylül aylarında çiçeklenir. Akd. El.

\section{Familya: Oleaceae (Zeytingiller)}

\section{Fontanesia phillyreoides Labill. (cılbırtı)}

Yaprak döken, 3 m'ye kadar boylanabilen çalı-

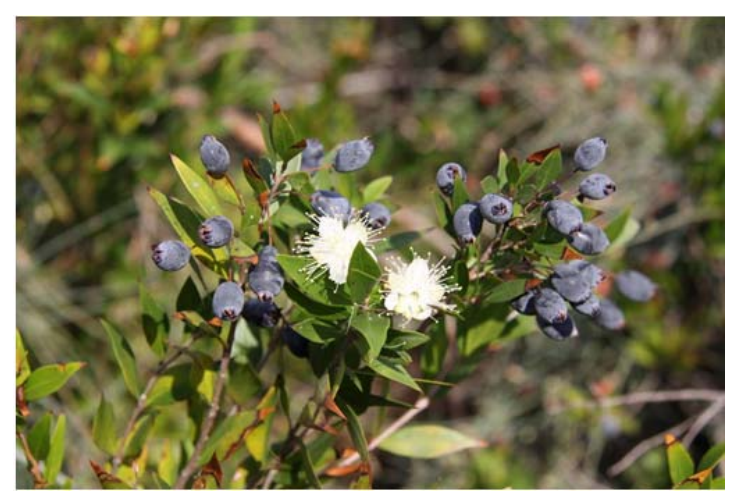

Fig. 33. Myrtus communis subsp. communis lar. Yapraklar eliptik-mızraksı. Çiçekler yoğun ve aromatik kokulu. Korolla 2-3 mm boyunda. Kremsi-beyaz renkli. Düz samara meyve eliptik ve kanatlı. Ülkemiz dışında Sicilya ve Lübnan'da yayılış gösterir. Nisan ayında çiçeklenen bu tür, 150-1550 m’ler arasındaki çoğunlukla kuru kayalık yerleri, makilikleri, kızılçam ormanlarını tercih eder. Akd. El.

\section{Olea europaea L. subsp. europaea (zeytin)}

10 m'ye kadar boylanabilen ağaçlar. Yapraklar mızraksı veya ters yumurtamsı, alt kısımda yoğun gümüşi tüylü. Çiçek durumları yapraklardan kısa. Çiçekler beyaz renkli, hoş kokulu. Eriksi meyve 
genç halde yeşil, olgun halde parlak ve siyah renkli. Mayıs ayında çiçeklenen meyveleri gıda sektörünün vazgeçilmez hammaddesidir. Yaprakları tansiyon ve kan şekerini düşürücü, iştah açıcı, idrar artıııı etkilere sahiptir. Zeytinyağından yapılan sabunları cilt ve saç bakımında kullanııı. Akd. El.

\section{Phillyrea latifolia L. (akçakesme)}

5 m'ye kadar boylanabilen herdem yeşil ağaç ve çalılar. Yapraklar yumurtamsı-kalpsiden yumurtamsı-mızraksıya kadar değişen şekillerde. Kaliks 4 loplu. Korolla yeşilimsi beyaz renkli. Eriksi meyve küresel, mavimsi siyah renkli. Yetişme ortamı olarak 10-1350 m'ler arasındaki makiliklerdeki kuru alanları, kızılçam ormanlarını ve karışık ormanlıkları tercih eder. Çiçeklenme zamanı ise mayıs ayıdır. ÇBFCB.

\section{Familya: Papaveraceae (Haşhaşgiller)}

Glaucium flavum Crantz (gündürmelâlesi) (Fig. 34) iki veya çok yıllık otsu bitkiler. Gövde 30-50 cm boyunda. Taban yaprakları lirat-pinnatifid parçalı. Sepaller tüylü. Petaller genellikle sarı nadiren kırmızımsı veya kırmızımsı-leylak renkli. Meyve 12-25 $\mathrm{cm}$ boyunda. Mayıs-temmuz aylarında çiçeklenen bu tür, ülkemizde deniz seviyesindeki kıyı ve kıyıya yakın bölgelerde yayılış göstermektedir. ÇBFCB.

\section{Papaver rhoeas L. (gelincik)}

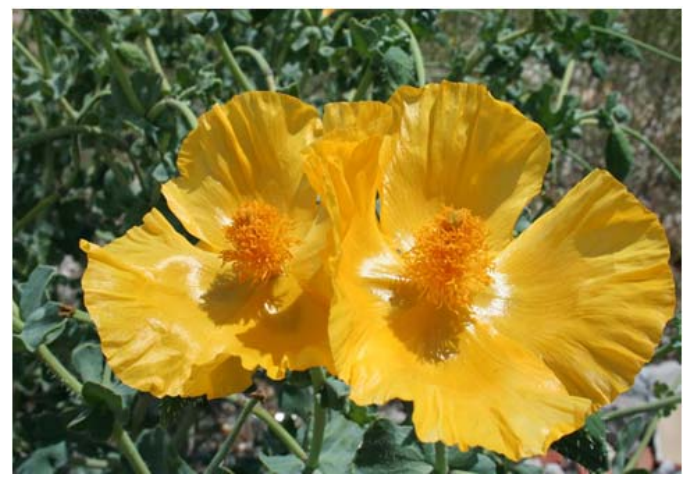

Fig. 34. Glaucium flavum

$90 \mathrm{~cm}$ 'ye kadar boylanabilen dik gövdeli tek yıllık otsu bitkiler. Yapraklar pinnatifid veya pinnatisekt parçalı. Petaller kırmızı, nadiren beyaz renkli. Kapsül meyve küreselden yarı küresele kadar değişen şekillerde. Ülkemizde geniş bir yayılış alanına sahip olan bu tür, mart-ağustos aylarında çiçeklenir. Yetişme ortamı olarak deniz seviyesinden 1400 m'ye kadar olan yüksekliklerdeki tarlaları ve nemli yerleri tercih eder. ÇBFCB.

\section{Familya: Plantaginaceae (Sinirotugiller)}

\section{Cymbalaria microcalyx (Boiss.) Wettst. (hoş nakkaşotu) (Fig. 35)}

Kayalar üzerinde sürünücü olarak yetişen çok yıllık otsu bitkiler. Yapraklar uzun saplı, kalpsi-dairesel veya böbreksi. Korolla beyaz veya soluk leylak, üst dudak menekşe damarlı, boğaz kapağı ise sarı renkli. Mahmuz 2.5-4 mm boyunda. Ülkemizde Muğla, Antalya ve Mersin illerinde, ülkemiz dışında ise Yunanistan, Arnavutluk, Ege Adaları'nda ve batı Balkanlarda yayılış gösteren bu tür, mart-mayıs aylarında çiçeklenir. Yetişme ortamı ise 30-700 m'ler arasındaki deniz kenarındaki kireç taşlı kayalık yerlerdir. Akd. El.

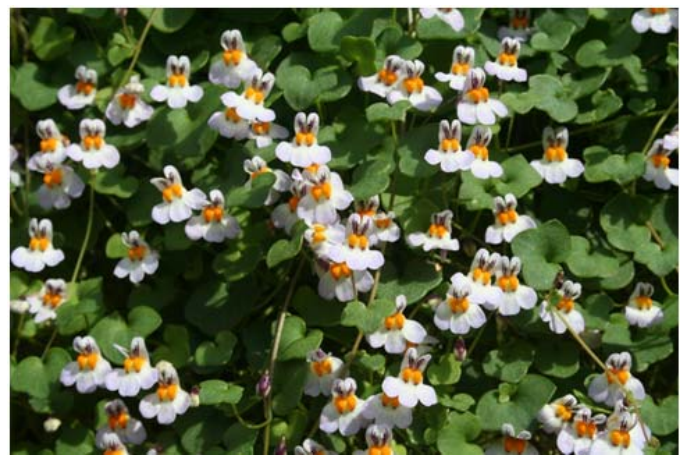

Fig. 35. Cymbalaria microcalyx

\section{Kickxia elatine (L.) Dumort. subsp. crinita (Mabille) Greuter (fukaraotu)}

Sürünücü gövdeli, sert kıllı tüylü veya uzun yumuşak tüylü tek yıllık otsu bitkiler. Yapraklar yumurtamsı, tabanda zıpkınsı veya ok başlı. Korolla sarı renkli, üst dudak koyu menekşe renkli. Mahmuz 5-6 mm boyunda düz veya kıvrık. Meyve kapsül. Yetişme ortamı olarak deniz seviyesinden 1600 m’ye kadar olan yüksekliklerdeki nemli yerleri tercih eder. Çiçeklenme zamanı ise 
haziran-ağustos aylarında çiçeklenir. Akd. El.

\section{Plantago afra L. (ateşyaprağı)}

10-40 cm boyunda tek yıllık otsu bitkiler. Gövde alt kısımda dallı; dalcıklar dik, yükselici veya kalkık uçlu. Yapraklar şeritsi-mızraksı veya şeritsi. Başak çiçek durumu yumurtamsı. Sepaller ters mıraksı. Korolla tüpü 3-3.5 mm boyunda. Kapsül meyve elipsoid. Yetişme ortamı olarak deniz seviyesinden 900 m’ye kadar olan yüksekliklerdeki ıslak çayırları, kumul alanları, taşlık alanları, tarlaları ve demiryolu kenarlarını tercih eden tür, mart-haziran aylarında çiçeklenir. ÇBFCB.

Familya: Platanaceae (Çınargiller)

Platanus orientalis L. (çınar)

30 m'ye kadar boylanabilen, yaprak döken ağaçlar. Yapraklar palmat, derin 3-5(-7) loplu. Çiçekler tek evcikli, sarkık küresel kafalarda. Tepaller 2 halkada toplam 3-8 adet. Meyve tabanda tüyler tarafından çevrilmiş fındık. Mart-mayıs aylarında çiçeklenen çınar, ülkemizin hemen hemen tüm bölgelerinde yayılış gösterir. Yetişme ortamı olarak ise deniz seviyesinden 1300 m'ye kadar olan yüksekliklerdeki nehir ve ırmak kenarlarını, alüvyonca zengin toprakları, ormanları ve kültür arazilerini tercih eder. ÇBFCB.

Familya: Plumbaginaceae (Kardikenigiller)

Limonium gmelinii (Willd.) Kuntze (çardaksüpürgesi)

30-60 cm boyunda, çok yıllık otsu bitkiler. Yapraklar genişçe eliptikten dikdörtgenimsi-ters yumurtamsıya kadar değişir. Kaliks ters konik, 2-3 mm boyunda. Petaller mavimsi menekşe renkli. Meyve darca elipsiod ve basık. Ülkemizde geniş bir yayılış alanına sahip olan bu tür, yetişme ortamı olarak ise deniz seviyesinden 1450 m'ye kadar olan yüksekliklerdeki, deniz kenarındaki ve iç kesimlerdeki tuzcul alanları tercih eder. Çiçeklenme zamanı ise mayıs-ekim aylarıdır. Avr.-Sib.El.

\section{Limonium virgatum (Willd.) Fourr. (kuduzotu)}

Yarı çalımsı, tabanda dallı, çok yıllık otsu bitkiler. Yapraklar dikdörtgenimsiden mızraksı-kaşıksı. Brakteler kahverengi. Kaliks hemen hemen ibrik şeklinde. Petaller açık menekşe renkli.Haziranekim aylarında çiçeklenen bu tür, deniz kenarlarındaki kayalıklarda, tuzlu nemli tarlalarda yetişir. Akd. El.

\section{Familya: Polygonaceae (Madımak)}

Polygonum maritimum L. (sicimlik)

Narin yapılı, çok yıllık otsu bitkiler. Gövde yatık ve 50 cm'ye kadar çıkar. Boğum kını 8-12 damarlı, tabanda kahve renkli. Yapraklar eliptik, sapsız. Çiçekler yaprak kenarlarında kümelenmiş. Periyant beyaz renkli. Meyve fındıksı ve kahve renkli. Deniz kenarındaki, kum tepelerinde ve kumlu alanlarda yetişir. ÇBFCB.

Familya: Primulaceae (Çuhaçiçeğigiller)

Anagallis arvensis L. var. arvensis (farekulağı)

7-70 (-90) cm boyunda, çıplak, tek yıllık otsu bitkiler. Gövde eğik tırmanışı, dik veya kalkık uçlu. Yapraklar yumurtamsı-dikdörtgenimsi. Pedisel $35 \mathrm{~mm}$ boyuna kadar çıkar. Korolla kırmızı veya turuncu renkli. Nisan-eylül aylarında çiçeklenen bu varyete, yetişme ortamı olarak ise deniz seviyesinden 1400 m'ye kadar olan yüksekliklerdeki kültür alanlarını, nehir yataklarını ve kayalık yamaçları tercih eder. ÇBFCB. 


\section{Cyclamen graecum Link subsp. anatolicum letsw. (domuztopalağı)}

Küresel veya yarıküresel tuberli bitkiler. Yapraklar çiçeklenmeden hemen sonra meydana gelir, kalpsi. Korolla soluk pembe, nadiren beyaz, tabanda kulakçıklı. Meyve kapsül. Bu alt tür, yetişme ortamı olarak 100 m'ye kadar olan yüksekliklerdeki kızılçam ormanlarında, kireç taşlı kayalıkları, meşe makiliklerini, kumlu ve kayalık yerleri tercih eder. Ülkemizde sadece Antalya'da, ülkemiz dışında ise güneydoğu Ege Adaları ve kuzey Kıbrıs'ta yayılış gösteren bu domuztopalağı, eylülkasım aylarında çiçeklenir. ÇBFCB.

\section{Familya: Ranunculaceae (Düğünçiçeğigiller)}

\section{Anemone coronaria L. (Manisalâlesi)}

8-30 cm boyunda, yumrulu, çok yıllık bitkiler. Taban yaprakları üçlü şekilde birleşik, dikgörtgenimsi. İnvolukral yapraklar sapsız. Tepaller genellikle 5-6 adet, kırmııı, pembe, menekşe-mor veya beyaz renkli. Aken meyve uzun yoğun yumuşak sık tüylü. Ülkemizde Marmara, Ege, Akdeniz ve Karadeniz Bölgeleri'nde yetişen bu tür, şubat-nisan aylarında çiçeklenir. Yetişme ortamı olarak deniz seviyesinden 900 m’ye kadar olan yüksekliklerdeki çalııkları, yamaçları ve çayırlıkları tercih eder. Akd. El.

\section{Clematis cirrhosa L. (bahar sarmaşığı)}

Çok yıllık odunlu tırmanıc bitkiler. Yapraklar karşııklı dizilişli. Çiçekler tek veya küme halinde. Periyant segmentleri krem renkli. Meyve aken. Mart ve nisan aylarında çiçeklenen bu tür, yetişme ortamı olarak ise deniz seviyesinden 350 m'ye kadar olan yüksekliklerdeki makilikleri ve çalılık alanları tercih eder. Akd. El.

\section{Ranunculus arvensis L. (mustafaçiçeği)}

Seyrek basık-uzun tüylü, 5-30 cm boyunda, 5-30 cm boyunda tek yıllık otsu bitkiler. Alt yapraklar üç parçalı veya üç loblu. Sepaller basık. Petaller sarı renkli. Aken meyveler ters yumurtamsıdairesel. Ülkemizin hemen hemen tüm bölgelerinde yayılış gösteren bu tür, mart-haziran aylarında çiçeklenir. Yetişme ortamı olarak deniz seviyesinden 700 m'ye kadar olan yüksekliklerdeki mısır tarlaları ve değişil habitatları tercih eder. ÇBFCB.

\section{Staphisagria macrosperma Spach (bitotu)}

Sağlam yapılı iki yıllık otsu bitkiler. Gövde 30-100 cm boyunda, yumuşak-sert kıllı tüylü. Gövde yaprakları elsi. Çiçekler mavi renkli, 15-20 mm boyunda. Folikül meyvenin bir yarı şişkin. Ülkemizde Ege ve Akdeniz Bölgeleri'nde yayılış gösteren bu tür, mayıs ve haziran aylarında çiçeklenir. Yetişme ortamı olarak deniz seviyesinden 700 m'ye kadar olan yüksekliklerdeki ormanlıkları, nemli ve kalkerli kayalık yerleri tercih eder. Akd. El.

\section{Familya: Rhamnaceae (Cehrigiller)}

\section{Paliurus spina-christi P. Mill. (karaçalı)}

Yaprak döken, 2-4 m boyunda, dikenli çalılar. Yapraklar yumurtamsı. Sepaller çıplak. Çiçekler sarı renkli. Meyve sert ve kuru, basık-küresel, $2-2.5 \mathrm{~cm}$ çapında. Ülkemizde oldukça geniş bir yayııış alanına sahip olan bu tür, mayıs-temmuz aylarında çiçeklenir. Yetişme ortamı olarak ise deniz seviyesinden 1400 m’ye kadar olan yüksekliklerdeki nehir vadilerini, açıklıkları ve nemli yerleri tercih eder. ÇBFCB. 
Familya: Rosaceae (Gülgiller)

Amygdalus graeca Lind. (şeytanbademi) (Fig. 36)

Dikenli, 2 m'ye kadar boylanabilen çalılar. Yapraklar ters yumurtamsı, alt kısımda yoğun beyazkeçemsi tüylü. Çiçekler pembemsi, daha sonra beyazımsı renkli. Eriksi meyve yumurtamsı. Frigana içinde, 10-500 m’ler arasındaki yüksekliklerdeki kireç taşı kayalıkları yetişme ortamı tercih eden bu tür, ocak-mart aylarında çiçeklenir. Akd. El.

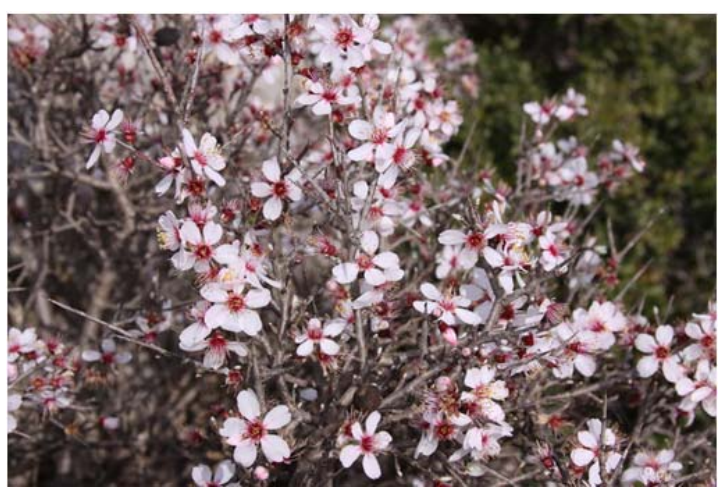

Fig. 36. Amygdalus graeca

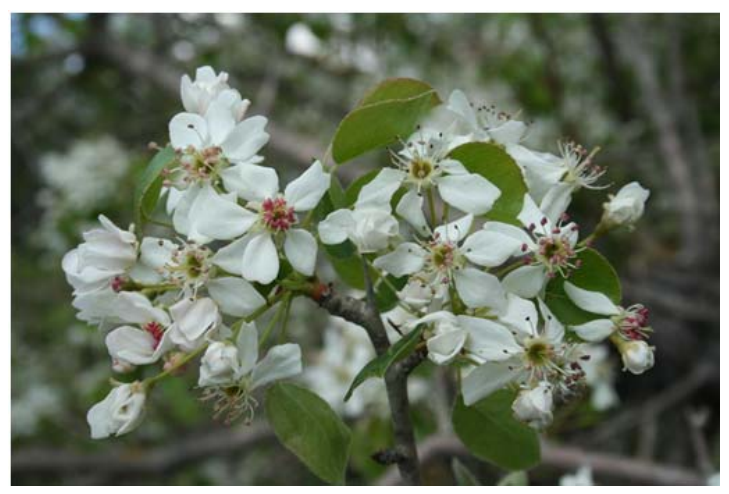

Fig. 37. Pyrus serikensis

\section{Creategus monogyna Jacq. subsp. monogyna (yemişen)}

10 m'ye kadar boylanabilen çalılar veya küçük ağaçlar. Yapraklar yumurtamsı veya ters yumurtamsı, derin parçalı. Çiçekler beyaz veya pembe renkli. Meyveler kırmızı veya kahve renklikırmızı, yarı küresel veya yumurtamsı. Nisan-haziran aylarında çiçeklenen bu bitki, yetişme ortamı olarak deniz seviyesinden 1800(-2000) m'ye kadar olan yüksekliklerdeki tepelikleri, makilikleri, meşe çalıııklarını, karışık ormanı ve yol kenarlarını tercih eder. ÇBFCB.

Pyrus serikensis Güner \& H. Duman (zingit) (Antalya endemiği) (Fig. 37)

10 m'ye kadar boylanabilen dikenli çalılar veya ağaçlar. Yapraklar yumurtamsıdan dairemsiye, nadiren eliptiğe kadar değişen şekillerde. Sepaller üçgenimsi. Petaller beyaz renkli. Meyve küresel. Ülkemize özgü olan bu tür, sadece Antalya ilinde yetişmektedir. Yetişme ortamı olarak meşelik alanları, tarlaları ve yol kenarlarını tercih eden bu bitki, mart ayında çiçeklenir. Akd. El.

\section{Rubus sanctus Schreb. (böğürtlen)}

1-2 m boyunda çalılar. Yapraklar ternat veya 5 parçalı pedat; yaprakçıklar ters yumurtamsı veya dairesel. Petaller pembe renkli. Meyveler ilk önce kırmızı olgunlaşınca siyah renkli. Yetişme orta mı olarak deniz seviyesinden 1250 m'ye kadar olan yüksekliklerdeki çalııkları, kayalık alanları, nehir kenarlarını ve boş arazileri tercih eder. Çiçeklenme zamanı ise haziran ağustos aylarıdır. ÇBFCB.

Familya: Rubiaceae (Kökboyagiller)

Plocama calabrica (L.f.) M. Backlund \& Thulin (belumçalısı) (Fig. 38)

Tabanda odunlu (5-)10-20(-30) cm boyunda çok yıllık bitkiler. Gövde yatık ve dallı. Yapraklar karşılıklı dizilişli, dikdörtgenimsi veya mızraksı. Korolla huni biçimli, pembe renkli. (8-)10-13(-17) mm boyunda. Eriksi meyve parlak ve kırmızı renkli. Mayıs-

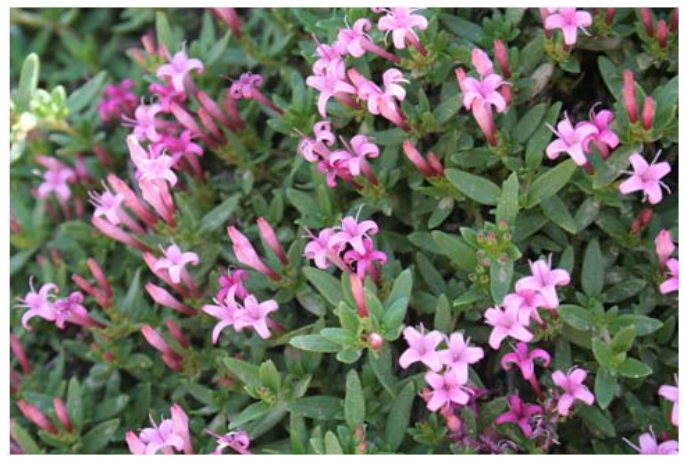

Fig. 38. Plocama calabrica 
ağustos ayında çiçeklenen bu tür, 2000 m’ye kadar olan kireçtaşlı kayalık yamaçlarda yetişir. Akd. El.

\section{Sherardia arvensis L. (gökörenotu)}

5-40 cm boyunda tek yıllık otsu bitkiler. Yapraklar halkasal, mızraksı. Çiçekler sapsız ve 4 parçalı. Kaliks 4-6 dişli. Korolla huni biçimli, leylak, pembemsi veya beyaz renkli. Merikarp yumurtamsı. Yetişme ortamı olarak deniz seviyesinden 1250 m'ye kadar olan yüksekliklerdeki orman ve çalı açıklıklarını, tarlaları ve yol kenarlarını tercih eden bu tür, nisan-eylül ayında çiçeklenir. Akd. El.

\section{Familya: Santalaceae (Güvelekgiller)}

Osyris alba L. (morcak)

iki evcikli çalılar. Gövde çok dallı, dik 0.25-2 m boyunda. Yapraklar şeritsi-mızraksı, derimsi. Çiçekler yeşilimsi-sarı renkli. Eriksi meyve kırmızı ve küresel. Yetişme ortamı olarak deniz seviyesinden 500 m’ye kadar olan yüksekliklerdeki kireçtaşlı kayalık yamaçları, makilikleri, çam ve meşe ormanlarını ve kale duvarlarını tercih eder. Akd. El.

\section{Familya: Sapindaceae (Akçaağaçgiller)}

Acer hyrcanum Fisch. \& C.A. Mey. subsp. sphaerocaryum Yalt. (kasnak akçaağaç) (Türkiye endemiği)

20 m'ye kadar boylanabilen ağaçlar. Yapraklar 5 loplu, hemen hemen yarıya kadar parçalı. Çiçekler dik, kısa saplı. Meyve samara. Ülkemize özgü olan bu bitki, sadece Antalya ve Afyon illerinde yayılış göstermekte olup kayalık yerlerde yetişir. Akd. El.

\section{Acer sempervirens L. (keleve)}

Yaprak döken veya kısmen herdem yeşil çalılar veya $5(-12) \mathrm{m}$ boyunda küçük ağaçlar. Yaprak ayası derimsi, genellikle yarıya kadar veya daha az 3 loplu, tabanda yuvarlak veya kalpsi; loplar geniş̧̧e yumurtamsı-üçgenimsi. Meyve samara. Baharda çiçeklenen bu tür, kireçtaşlı kayalık yamaçları ve boğazları tercih eder. Ülkemizde İzmir, Muğla ve Antalya illerinde yayııış gösterir. Akd. El.

\section{Familya: Scrophulariaceae (Sıracaotugiller)}

\section{Scrophularia lucida L. (zorlakotu)}

130 cm'ye kadar boylanabilen, çıplak, tek veya çok yıllık otsu bitkiler. Taban yaprakları yarı daireselden dikdörtgenimsi-kaşıksıya kadar değişen şekillerde. Korolla soluk kahverengi-pembeden kirli beyazımsı-kırmızımsıya kadar değişen renklerde; loplar kırmııımsı-kahverenkli. Kapsül meyve hemen hemen küresel. Ülkemiz dışında İtalya, Yunanistan, Ege Adaları, Kıbrıs, Suriye ve Kafkasya'da yayılış gösteren bu tür, mart-haziran aylarında çiçeklenir. Yetişme ortamı olarak ise 102200 m’ler arasındaki kireç taşlı ve serpantin kaya yarıkların, kayalık yamaçları ve kuru nehir yataklarını tercih eder. Akd. El.

\section{Verbascum chazaliei Boiss. (çam sığırkuyruğu) (Antalya endemiği)}

Tabanda odunsu, 1-2 m boyunda, yoğun keçemsi tüylü. Taban yaprakları ters yumurtamsıdan geniş̧̧e mızraksıya kadar değişen şekillerde. Kaliks 7-8 mm boyunda. Korolla sarı renkli ve 15-20 mm çapında. Antalya iline özgü olan bu tür, mayıs ayında çiçeklenmekte olup, yetişme ortamı olarak deniz seviyesinden 300 m'ye kadar olan yüksekliklerdeki kızılçam ormanlarını, makilikleri ve serpantin kayalıkları tercih eder. Akd. El. 
Verbascum levanticum I.K. Ferguson (arap sığırkuyruğu) (Fig. 39a-b)

Tek, iki veya çok yıllık otsu bitkiler. Taban yaprakları lirat-pinnatifid parçalı, yumurtamsı veya kalpsi. Kaliks $4 \mathrm{~mm}$ boyunda. Korolla sarı renkli ve 25-30 mm çapında. Kapsül meyve genişçe yumurtamsı veya yarı küresel. Ülkemizde sadece Antalya ilinde, ülkemiz dışında ise Kıbrıs, Lübnan ve Filistin'de yayılış göstermektedir. Yetişme ortamı olarak deniz seviyesinden 300 m'ye kadar olan yüksekliklerdeki kireç taşı kayalıkları, kaya üzerlerini, tarihi eserler üzerlerini ve tahrip edilmiş alanları tercih eder. Akd. El.

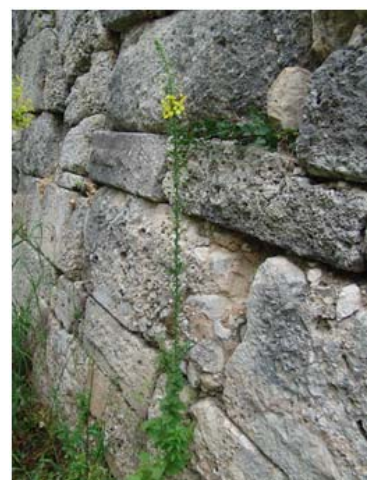

Fig. 39a. Verbascum levanticum

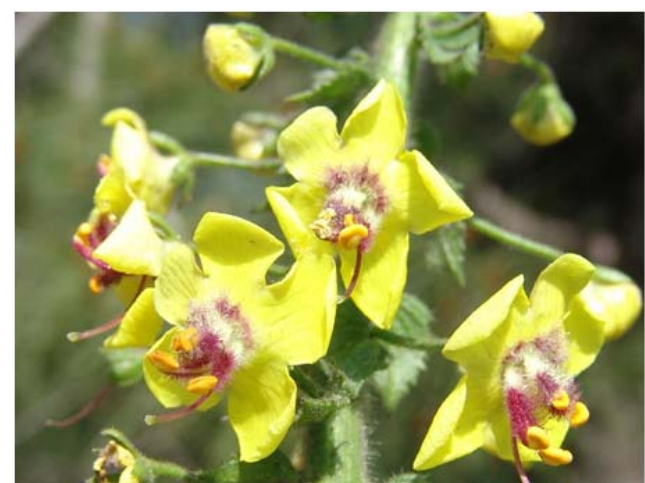

Fig. 39b. Verbascum levanticum Çiçeklerinin Yakın Görünüşü

Verbascum sinuatum L. subsp. sinuatum var. adenosepalum Murb. (bodanotu)

50-100 cm boyunda, genellikle tabanda dallı, iki yıllık otsu bitkiler. Taban yaprakları kaşıksı-dikdörtgenimsi. Kaliks 2.5-5 mm boyunda. Korolla sarı renkli ve 15-30 mm çapında. Kapsül meyve genişçe eliptik veya yarı küresel. Mayıs-ekim aylarında çiçeklenen bu varyete, yetişme ortamı olarak deniz seviyesinden 1100 m'ye kadar olan yüksekliklerdeki yol kenarlarını, tarla kenarlarını, stebi ve kıyı kumullarını tercih eder. Akd. El.

\section{Familya: Solanaceae (Patlıcangiller)}

Hyoscyamus aureus L. (sarı banotu)

30-60 cm boyunda, dik veya sarkık gövdeli çok yıllık otsu bitkiler. Yapraklar dairesel-yumurtamsı. Kaliks 15-20 mm boyunda, çiçekli halde 22-30 mm boyunda. Korolla altın sarısı renkli, boğaz kısmı mor renkli. Stamen uzun, anterler sarı. Meyve kapsül. Şubat-temmuz aylarında çiçeklenen bu tür, ülkemizde batı ve güney bölgelerinde yetişir. Yetişme ortamı olarak ise 1200 m’ye kadar olan yüksekliklerdeki kaya yarıklarını ve eski duvarları tercih eder. Akd. El.

Mandragora autumnalis Bertol (adamotu) (Fig. 40)

Gövdesiz veya çok kısa gövdeli, kalın dikey köklere sahip çok yıllık otsu bitkiler. Yapraklar saplı, yumurtamsıdan dikdörtgenimsi-mızraksıya kadar değişen şeklerde. Korolla çan şeklinde soluk mavisi menekşe renkli. Üzümsü meyve sarıdan turuncuya kadar değişen renklerde. Illk kez İtalya'dan toplanarak bilim dünyasına tanıtılan bu tür, yetişme ortamı olarak deniz seviyesinden 600 m'ye kadar olan yüksekliklerdeki kayalık yamaçları, kııılçam orman

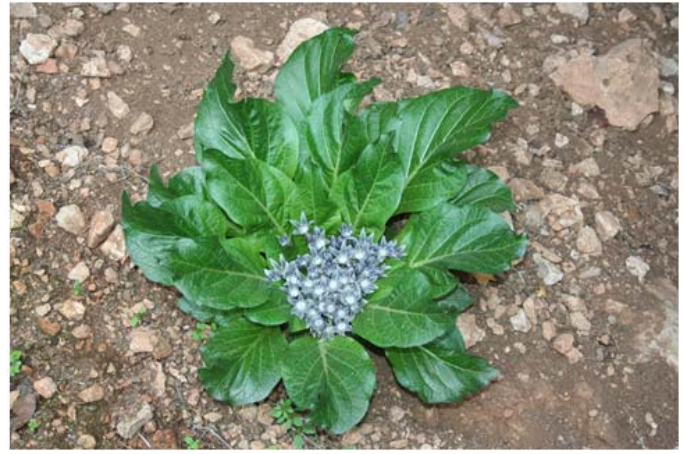

Fig. 40. Mandragora autumnalis 
altlarını ve tarlaları tercih eder. Çiçeklenme zamanı ise ocak-nisan aylarıdır. Akd. El.

Familya: Styracaceae (Ayıfındığıgiller)

Styrax officinalis L. (ayıfındığı)

Yaprak döken çalı veya ağaçlar. Gövde çok dallı, 6 m’ye kadar boylanır. Yapraklar geniş eliptikte yumurtamsıya kadar değişen şekillerde. Çiçekler 3-6'lı kümelerde ve kokulu. Korolla beyaz renkli. Eriksi meyve küresel veya dikdörtgenimsi. Nisan-haziran aylarında çiçeklenen bu tür, yetişme ortamı olarak deniz seviyesinden 1500 m'ye kadar olan yüksekliklerdeki kızılçam ormanlarını, makilikleri ve yaprak döken çalııkları tercih eder. ÇBFCB.

Familya: Thymelaeaceae (Sıyırcıkgiller)

Daphne sericea Vahl. subsp. sericea (tavukbüzüğü)

$150 \mathrm{~cm}$ 'ye kadar boylanabilen dik çalılar. Yapraklar derimsi, eliptik veya eliptik-ters mızraksı. Çiçekler uçta veya kenarda, hemen hemen kokulu. Periyant pembe, ipeksi tüylü. Meyve yumurtamsı. Yetişme ortamı olarak 1500 m’ye kadar olan yüksekliklerdeki kireç taşlı kayalıkları, sepantin arazileri, kızılçam açıklıklarını, Quercus coocifera-Arbutus makiliklerini tercih eden bu alt tür, şubat-mayıs aylarında çiçeklenir. Akd. El.

\section{Sınıf: Liliopsida (Monokotiller)}

Familya: Amaryllidaceae (Nergisgiller)

Allium bourgeaui Rech. fil. subsp. bourgeaui (sahil soğanı)

Çok yıllık soğanlı bitkiler. Gövde 45-115 cm boyunda. Yapraklar 4-11 tane, 6-25 mm eninde. Şemsiyemsi çiçek durumu küresel, 3-6 cm çapında. Periyant segmentleri soluk yeşil veya mor renkli. Anterler sarı renkli. Kapsül meyve yaklaşık 4 mm. Burdur, Antalya ve Rodos Adası'nda yayılış gösteren bu alt tür yetişme ortamı olarak 50-800 m’ler arasındaki kayalık yamaçları ve kireç taşlı sarp yamaçları tercih eder. Çiçeklenme zamanı ise haziran ve temmuz aylarıdır. Akd. El.

\section{Allium neapolitanum Cyr. (sarımsak çiçeği)}

Çok yıllık soğanlı bitkiler. Soğanlar yarı küresel. Gövde 20-50 cm boyunda. Yapraklar 2 adet, genişçe şeritsi. Şemsiye çiçek durumu dik sütunsu kümeli. Periyant segmentleri beyaz renkli. Kapsül meyve $5 \mathrm{~mm}$. ilk kez Italya'dan toplanarak bilim dünyasına tanıtılan bu yabani sarımsak çiçeği, yetişme ortamı olarak deniz seviyesinden 1035 m'ye kadar olan yüksekliklerdeki makilikleri, friganayı, kayalık yerleri ve nemli yerleri tercih eder. Çiçeklenme zamanı ise mart-mayıs aylarında çiçeklenir. Akd. El.

Galanthus elwesii Hooker f. var. monostictus P. D. Sell (kardelen) (Türkiye endemiği) (Fig. 41)

30 cm'ye kadar boylanabilen çok yıllık soğanlı bitkiler. Yapraklar darca ters-mızraksı. Çiçekler beyaz renkli. Meyve genişçe elipsiodden küresele kadar değişen kapsül. Bu varyetenin çiçeklenme zamanın sonbahar olup, deniz seviyesinden 250 m'ye kadar olan yüksekliklerde yetişmektedir. Akd. El.

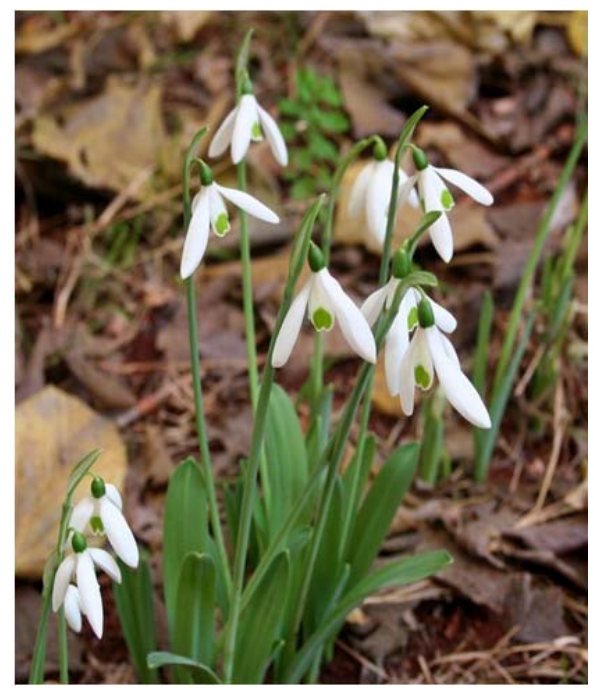

Fig. 41. Galanthus elwesii var. monostictus 


\section{Narcissus tazetta L. var. tazetta (nergis)}

Soğanlı ve 65 cm'ye kadar boylanabilen çok yıllık bitkiler. Yapraklar düz. Çiçek durumu 2-10 (-15) çiçekli şemsiye. Periyant segmentleri beyaz, korona ise sarı renkli. Kapsül meyve elipsoidyarıküresel. Yetişme ortamı olarak deniz seviyesinden 850 m’ye kadar olan kızılçam ormanını, deniz kıyısındaki kayalıkları, makilikleri ve kireç taşı yarıklarını tercih eden bu varyete kasımmayıs ayları arasında çiçeklenmektedir. ÇBFCB.

\section{Pancratium maritimum L. (kum zambağı) (Fig. 42)}

40 cm'ye kadar boylanabilen çok yıllık soğanlı bitkiler. Yapraklar çiçeklenmeden önce mevcut. Şemsiyemsi çiçek durumu 3-10 çiçekli. Çiçekler beyaz renkli. Meyve kapsül. Haziran-ekim ayları arasında çiçeklenen kum zambağı, ülkemizin güney ve kuzey sahillerindeki kumullarda yayılış göstermektedir. Akd. El.

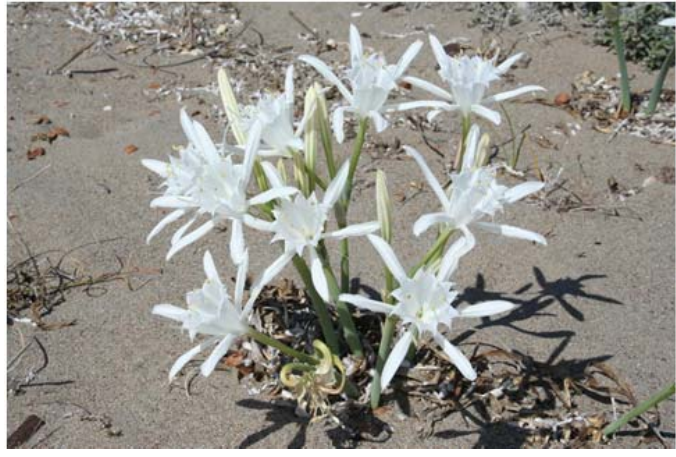

Fig. 42. Pancratium maritimum

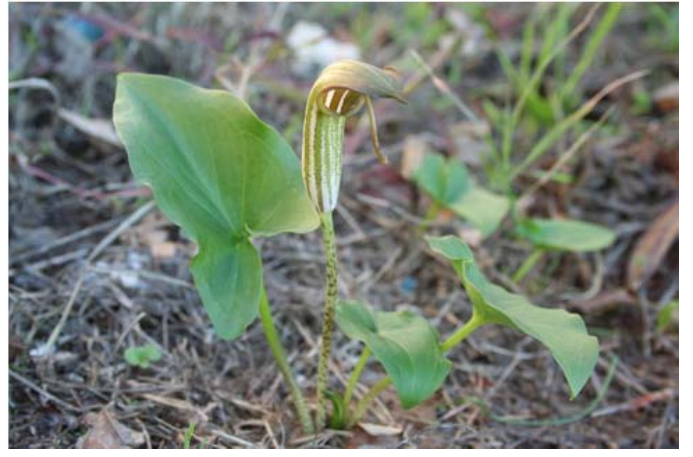

Fig. 43. Arisarum vulgare

Familya: Araceae (Yılanyastığıgiller)

\section{Arisarum vulgare O.Targ. Tozz. (yılancıkotu) (Fig. 43)}

$20 \mathrm{~cm}$ 'ye kadar boylanabilen, yumurtamsı yumrulara sahip bitkiler. Yapraklar uzun; lamina yumurtamsı-oksu. Çiçek durumunu çevreleyen spata alt kısımda beyazımsı veya soluk yeşilimsi ve koyu çizgili. Üzümsü meyveler bastırılmış küresel. Ülkemizde Marmara, Ege ve Akdeniz Bölgeleri'nde yayılış gösteren bu tür, kasım-mayıs aylarında çiçeklenir. Yetişme ortamı olarak ise 10700 m’ler arasındaki kayalık tepelikleri, kireçtaşlı ve metamorfik kayalıkları, kermes meşesi çalılıklarını meşe ormanlarını ve gölgeli duvarları tercih eder. Akd. El.

\section{Arum dioscoridis Sm. var. dioscoridis (tirşik pancarı) (Fig. 44)}

Dikey duruşlu yumruya sahip çok yıllık otsu bitkiler. Yapraklar uzun saplı; lamina dar veya uzamış zıpkınsı. Çiçek durumunu çevreleyen spata dışta yeşilimsi veya morumsu içte beyaz, hafif bordo, pembe veya morumsu. Üzümsü meyveler kırmızı. Bu varyete ülkemizde sadece Antalya ilinde ülkemiz dışında ise Kıbrıs'ta yayılış göstermektedir. Çiçeklenme zamanı mart-mayıs (-haziran) aylarında çiçeklenen bitki, yetişme ortamı olarak deniz seviyesinden 2500 m'ye kadar olan yüksekliklerdeki açık kireç taşı kayalık yamaçları ve yarıklarını, tarla kenarlarını ve yol kenarlarını tercih eder. Akd. El.

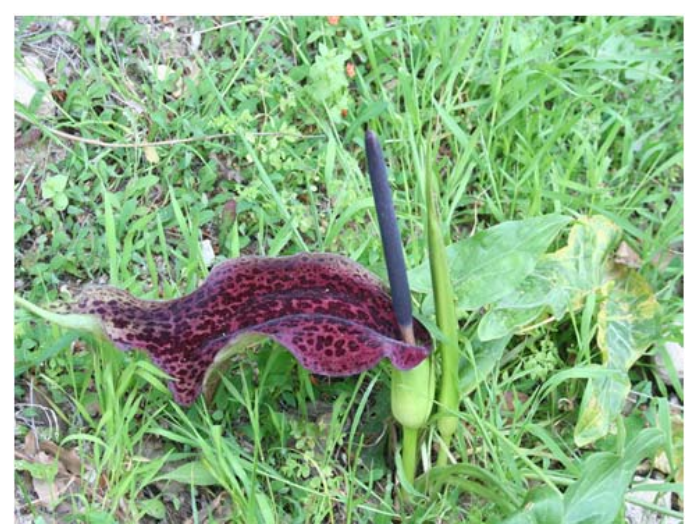

Fig. 44. Arum dioscoridis var. dioscoridis 
Familya: Asparagaceae (Kuşkonmazgiller)

Asparagus acutifolius L. (tilkişen)

Odunlu, yükselici veya tırmanıcı bitkiler. Kladotlar dikensi, her kümede 5-12 adet. Erkek periyant segmentleri sarısı veya yeşilimsi renkli.Üzümsü meyve siyah renkli. Ağustos ve eylül aylarında çiçeklenen bu kuşkonmaz türü, yetişme ortamı olarak deniz seviyesinden 1525 m’ye kadar olan yüksekliklerdeki çam ormanlarını, makilikleri, bozulmuş alanları ve yol kenarlarını tercih eder. Akd. El.

\section{Drimia maritima (L.) Stearn (kum örümcekotu) (Fig. 45)}

5-15 cm çapında soğanlara sahip bitkiler. Çiçek kümesi gövdesi 1-1.5 m boyunda. Yapraklar tabanda, çiçeklenme zamanında mevcut değil. Periyant segmentleri beyaz renkli, kırmızı veya yeşil hatlı. Kapsül meyve üç köşeli. Ülkemizde Ege ve Akdeniz Bölgeleri'ndeki sahil kenarlarında, ülkemiz dışında ise Akdeniz havzasında ve güney İran'da yetişmektedir. Ekim ve kasım aylarında çiçeklenen bu tür, yetişme ortamı olarak deniz seviyesinden 300 m’ye kadar olan yüksekliklerde yetişir. Akd. El.

\section{Muscari comosum (L.) Mill. (morbaş)}

1.5-3.5 cm çapında soğanlara sahip çok yıllık bitkiler. Yapraklar 3-5 $(-7)$, şeritsi.Verimli çiçekler alt kısımda soluk kahve renkli, verimsiz çiçekler parlak menekşe ve belirgin bir koma şeklinde. Kapsül meyve genişçe yumurtamsı-eliptikten yarı dairesele kadar değişen şekillerde. Ülkemizde oldukça geniş bir yayııış alanına sahip olan bu tür, mart-temmuz aylarında çiçeklenmekte olup, yetişme ortamı

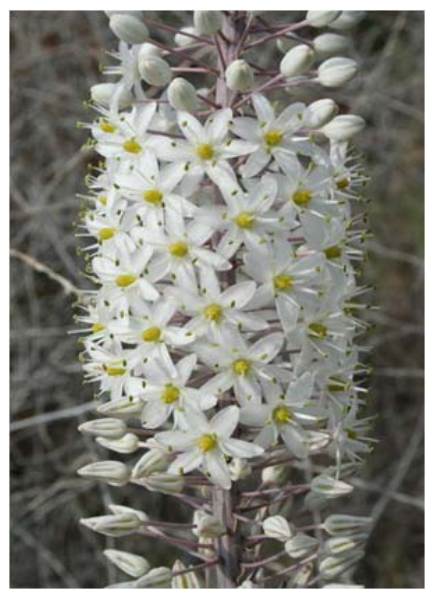

Fig. 45. Drimia maritima olarak deniz seviyesinden 2400 m'ye kadar olan yüksekliklerdeki kızılçam ormanlarını, meşe odunluklarını, kayalık yamaçları ve nehir kıyılarını tercih eder. Akd. El.

\section{Ornithogalum narbonense L. (akbaldır)}

Çok yıllık soğanlı bitkiler. Çiçek kümesi gövdesi 80-100 cm boyunda. Yapraklar çok sayıda şeritsi. Periyant segmentleri beyaz renkli. Kapsül meyve yumurtamsı veya yumurtamsı-silindirik. Yetişme ortamı olarak deniz seviyesinden 3000 m'ye kadar olan yüksekliklerdeki yamaçları, tarlaları, yol kenarlarını ve nemli yerleri tercih eder. Çiçeklenme zamanı nisan-mayıs aylarıdır. Akd. El.

\section{Ornithogalum pyrenaicum L. (eşek susamı)}

Çok yıllık soğanlı bitkiler. Çiçek kümesi gövdesi 30-100 cm boyunda. Yapraklar şeritsi, 2-4 mm eninde, çiçek kümesi gövdesinden kısa. Salkım çiçek durumu 7-17 cm boyunda, 25-40 çiçekli. Periyant segmentleri iç kısımda soluk sarı, dış kısımda yeşilimsi renkli. Kapsül meyve yumurtamsı-terskonik. Yetişme ortamı olarak deniz seviyesinden 1400 m'ye kadar olan yüksekliklerdeki, kayalık yerleri, yamaçları ve çayırlıkları tercih eden bu tür, mayıs-haziran aylarında çiçeklenir. ÇBFCB.

\section{Prospero autumnalis (L.) Speta (güz sümbülü)}

Soğanlı çok yıllık bitkiler. Çiçek kümesi gövdesi dik, 5-30 cm boyunda. Yapraklar 3-12 adet, darca şeritsi. Periyant segmentleri parlak leylak renkli. Kapsül meyve yarı küresel. Sonbahar'da çiçeklenen bu tür, yetişme ortamı olarak deniz seviyesinden 1500 m'ye kadar olan yüksekliklerdeki kuru, güneşli çimenlikleri, makilikleri, kireç taşlı yerleri, orman açıkıklarını ve nemli yerleri tercih eder. Akd. El. 
Ruscus aculeatus L. (tavşanmemesi)

Basit dallı, dik, 20-50 cm boyunda rizomlu bitkiler. Kladotlar geniş̧̧e yumurtamsı-uzun sivri uçlu veya mızraksı uzun sivri uçlu ve uçta dikenli. Periyant segmentleri 6 adet, serbest. Üzümsü meyve 1-4 tohumlu, küresel ve kırmızı renkli. Yetişme ortamı olarak 30-1000 m'ler arasındaki kayalık yamaçları ve çalıııkları tercih eden bu bitki şubat-mayıs aylarında çiçeklenir. ÇBFCB.

Familya: Colchicaceae

Colchicum baytopiorum C. D. Brickell (güz çiğdemi) (Türkiye endemiği) (Fig. 46)

Çok yıllık gövdesiz kormlu bitkiler. Korm dar yumurtamsıdan yarı küresele kadar değişen şekillerde. Yapraklar 3-4 adet, darca mızraksı. Periyant segmentleri açık pembeden morumsuya kadar değişen renklerde. Kapsül meyve eliptik veya yumurtamsı. Ülkemize özgü olan bu tür, sadece Antalya ve Isparta illerinde yayılış göstermektedir. Yetişme ortamı olarak 50-1000 m'ler arasındaki maki ve kızıçam açıklıklarını tercih eder. Çiçeklenme zamanı ise ekim ve kasım aylarıdır. Akd. El.

Familya: Iridaceae (Süsengiller)

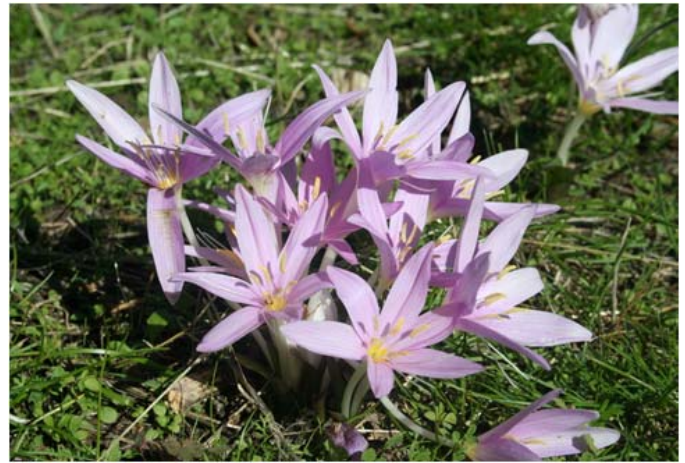

Fig. 46. Colchicum baytopiorum

Crocus wattiorum (B. Mathew) B. Mathew (kaya çiğdemi) (Olimpos-Beydağları Milli Parkı endemiği) (Fig. 47)

Çok yıllık kormlu bitkiler. Yapraklar 5 adet, çiçeklenme döneminde çok kısa gelişir. Periyantın boğazı sarı renkli, segmentler leylak-mavi renkli. Anterler açılmadan önce siyahımsı-kestane renkli, polenler sarı renkli. Stilus üç parçalı, turuncu renkli. Meyve kapsül. Olimpos-Beydağları Milli Parkı'na özgü olan bu çiğdem türü, 1995 yılında B. Mathew tarafından Crocus biflorus subsp. wattiorum olarak bilim dünyasına tanıtılmıştır. Ancak yine aynı araştırıcı tarafından Crocus wattiorum olarak tür seviyesine yükseltilmiştir. Yetişme ortamı olarak 100-

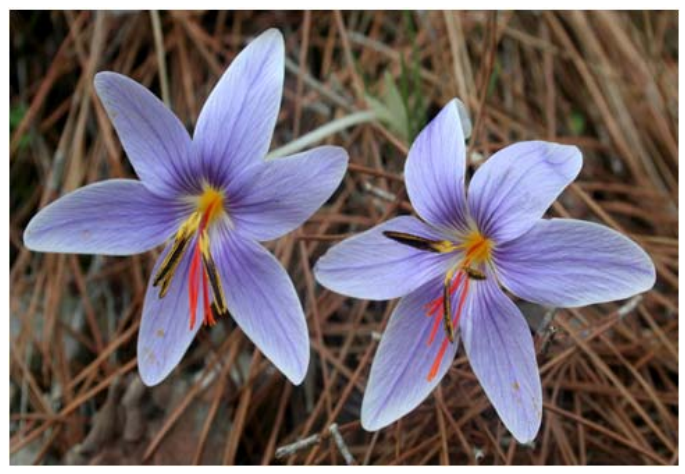

Fig. 47. Crocus wattiorum 1310 m'ler arasındaki kızılçam orman altlarını ve kaya yarıklarını tercih eden bu tür ekim ve kasım aylarında çiçeklenir. Akd. El.

\section{Gladiolus illyricus W.D.J. Koch (osman çiçeği)}

Çok yıllık kormlu bitkiler. Gövde 25-55 cm boyunda. Yapraklar 4 (-5) adet. Periyant gül pembesi veya koyu kırmızımsı pembe renkli. Anterler 13-14 (-25 mm) boyunda. Kapsül meyve eliptik. Nisan-haziran aylarında çiçeklenen bu glayöl, yetişme ortamı olarak deniz seviyesinden 1200 m’ye kadar olan yüksekliklerdeki kayalık yamaçları, karaçam orman açıkıklarını, friganayı ve dere kenarlarını tercih eder. Akd. El.

\section{Gynandriris sisyrinchium (L.) Parl. (keklik çiğdemi) (Fig. 48)}

Çok yıllık kormlu bitkiler. Gövde 5-30 (-40) cm boyunda. Yapraklar 2 adet, şeritsi. Çiçekler kısa ömürlü. Dış periyant lavanta mavisi, leylak veya mor renkli, üst kısmı beyaz veya sarı benekli. 
Kapsül meyve $20 \mathrm{~mm}$ boyunda (gaga hariç). Ülkemizde Marmara, Ege, Akdeniz ve Güney Doğu Anadolu Bölgeleri'nde yayılış gösteren bu tür şubat-mayıs aylarında çiçeklenir. Yetişme ortamı olarak deniz seviyesinden 1400 m'ye kadar olan yüksekliklerdeki kızılçam ormanlarını, kireç taşlı tepelikleri, makilikleri ve nemli yerleri tercih eder. ÇBFCB.

Iris unguicularis Poir. subsp. carica (Wern. Schulze) A.P. Davis \& Jury var. carica (çalı navruzu) (Türkiye endemiği) (Fig. 49a-b)

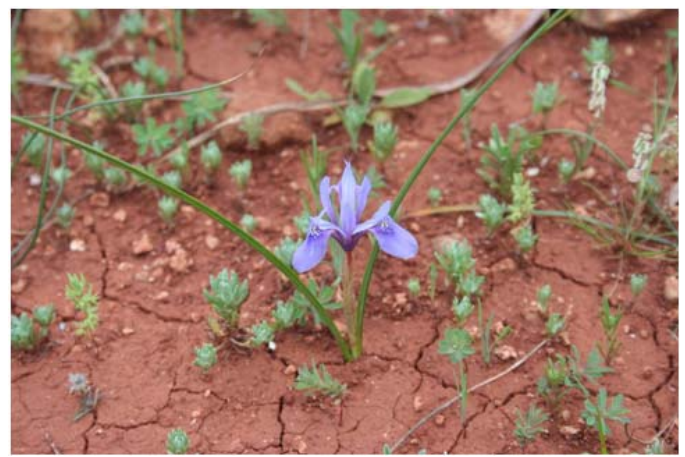

Fig. 48. Gynandriris sisyrinchium

12-40 cm boyunda, rizomlu çok yıllık bitkiler. Yapraklar şeritsi. Çiçekler lavanta mavisinden koyu leylak rengine kadar değişen renklerde, dış periyant segmentleri üzerinde sarı çizgili. Kapsül meyve eliptik. Şubat-haziran aylarında çiçeklenmekte olup, yetişme ortamı olarak ise deniz seviyesinden 1500 m'ye kadar olan yüksekliklerdeki kızılçam altlarını ve açıkıklarını, kayalık yerleri, nemli yerleri ve çalıık alanları tercih eder. Akd. El.

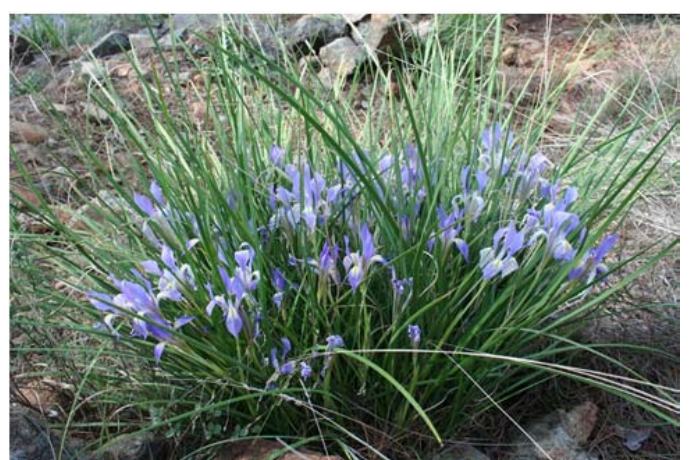

Fig. 49a. Iris unguicularis subsp. carica var. carica

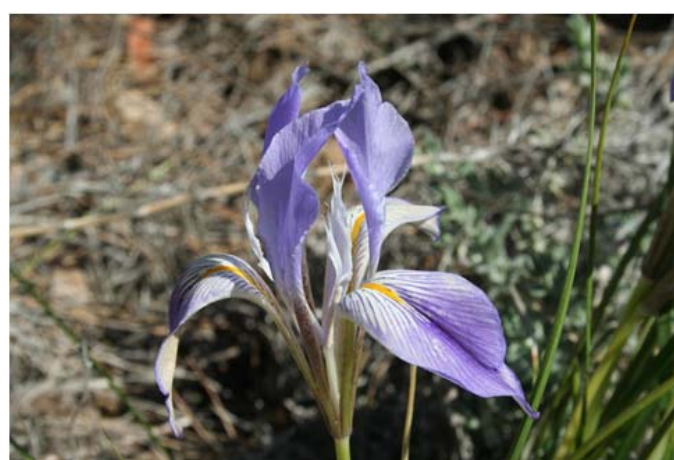

Fig. 49b. Iris unguicularis subsp. carica var. carica Çiçeğinin Yakın Görünüşü

\section{Romulea tempskyana Freyn (sarıboğaz)}

Kormlu çok yıllık bitkiler. Yapraklar 3-6 adet, 8-16 cm boyunda. Periyantın tüp kısmı sarı renkli, segmentler menekşe renkli. Meyve kapsül. Ülkemizde Ege ve Akdeniz Bölgeleri'nde, ülkemiz dışında ise Kıbrıs ve Filistin'de yetişen bu tür, ocak-mart aylarında çiçeklenir. Yetişme ortamı olarak ise 30-50 m'ler arasındaki kayalık yerler ve makilik alanları tercih eder. Akd. El.

\section{Familya: Liliaceae (Zambakgiller)}

Fritillaria acmopetala Boiss. subsp. acmopetala (duğuk) (Fig. 50a-b)

Soğanlı çok yıllık bitkiler. Gövde 15-45 cm boyunda. Yapraklar 4-11 adet, şeritsi. Periyant genişçe çansı; segmentler yeşil-kahverengi. Kapsül meyve kanatsız. Bu tür yetişme ortamı olarak 201000 m’ler arasındaki orman açıkıklarını, çalııkları ve mısır tarlalarını tercih eder. Akd. El.

\section{Gagea graeca (L.) Irmsch (sürmeli yıldız)}

Soğanlı çok yıllık bitkiler. Alt yapraklar 2 adet, şeritsi. Gövde yaprakları 3 adet. Periyant segmentleri beyaz renkli, 3 tane mor çizgili. Kapsül meyve darca yumurtamsı-dikdörtgenimsi. Ülkemizde Ege ve batı Akdeniz Bölgesi'nde, ülkemiz dışında ise Yunanistan ve Girit’te yayılış gösterir. Nisanmayıs aylarında çiçeklenen bu tür, yetişme ortamı olarak 100-1000 m'ler arasındaki kayalıklar 


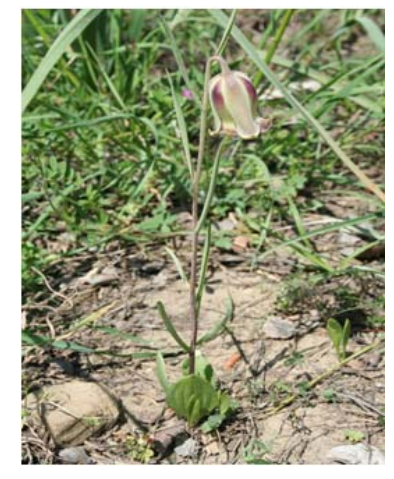

Fig. 50a. Fritillaria acmopetala subsp. acmopetala

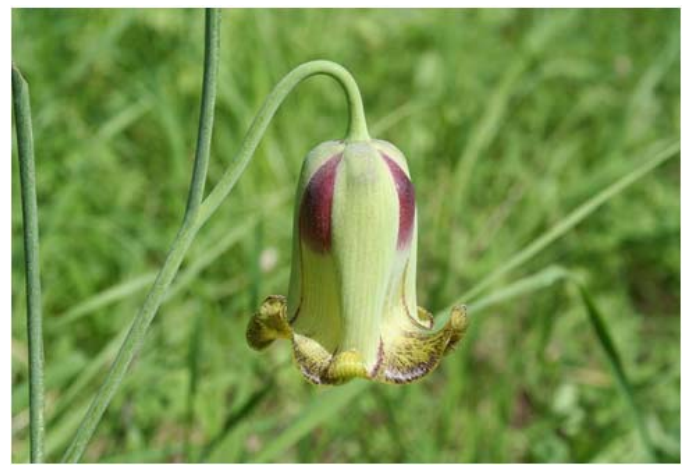

Fig. 50b. Fritillaria acmopetala subsp. acmopetala Çiçeğinin Yakın Görünüşü

üzerini ve maki aralarını tercih eder. Akd. El.

\section{Gagea peduncularis (C. Presl) Pascher (karga sarımsağı)}

Soğanlı çok yıllık bitkiler. Alt yapraklar 2-3 adet, şeritsi. Gövde yaprakları 1 adet. Periyant segmentleri sarı renkli. Kapsül meyve genişçe ters yumurtamsı. Yetişme ortamı olarak 10-1300 m’ler arasındaki kireç taşı kayalıklarını ve çam ormanlarını tercih eder ve şubat-nisan aylarında çiçeklenir. ÇBFCB.

\section{Familya: Orchidaceae (Salepgiller)}

\section{Barlia robertiana (Loisel) Greuter (patpatanak) (Fig. 51a-b)}

Sağlam yapılı yumrulu bitkiler. Gövde 20-60(-80) cm boyunda, kalın ve yapraklı. Yapraklar gövdenin tabanında, geniş ve hemen hemen etli, dikdörtgenimsi-mızraksı. Başak çiçek durumu 20 cm'ye kadar çıkar. Çiçekler güzel kokulu. Sepaller yumurtamsı, yeşilimsi kahve renkli, iç yüzey üzerinde mor benekli. Petaller dilsi, sepallerden kısa soluk yeşil. Labellum 15-22 mm boyunda beyazımsı-gül renkli bazen mor benekli. Mahmuz konik. Ülkemizde Muğla, Aydın ve Antalya illerinde, ülkemiz dışında ise bazı Ege Adaları'nda ve Kanarya Adası'nda yetişmektedir. Şubatnisan aylarında çiçeklenen tür, 630 m yüksekliğe kadar olan kalkerli tepelikleri, kayalık çimli açıklıkları, çam ve meşe ormanlıklarını, makilikleri ve friganayı tercih eder. Akd. El.

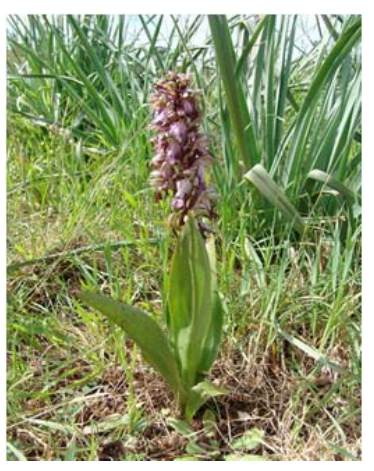

Fig. 51a. Barlia robertiana

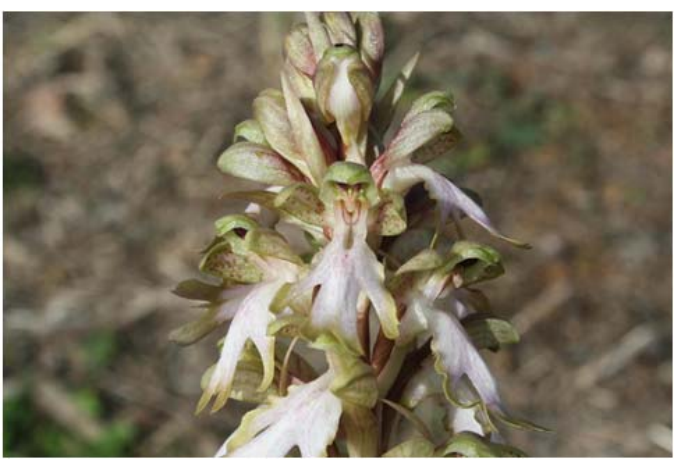

Fig. 51b. Barlia robertiana Çiçeklerinin Yakın Görünüşü

\section{Cephalanthera epipactoides Fisch. \& C. A. Mey. (ana çamçiçeği)}

30-100 cm boyunda rizomlu bitkiler. Gövde sağlam ve yapraklı. Yapraklar yumurtamsı-mızraksı. Başak çiçek durumu 40 cm'ye kadar çıkar. Çiçekler beyaz renkli. Sepaller mızraksı. Petaller yumurtamsı-mızraksı. Mahmuz konik. Meyve kapsül. Nisan-haziran ayında çiçeklenen bu tür, ye- 
tişme ortamı olarak deniz seviyesinden 1200 m’ye kadar olan yüksekliklerdeki makilikleri, çam ve meşe ormanlarını ve çalııkları tercih eder. Akd. El.

\section{Limodorum abortivum (L.) Swartz var. abortivum (saçuzatan) (Fig. 52 a-b)}

Sağlam yapılı, rizomlu, çürükçül, çok yıllık bitkiler. Gövde 30-80 cm boyunda, yeşilimsi-kurşunimenekşe renkli. Çiçekler 4-25 adet, menekşemsi renkli. Sepaller ters yumurtamsı-mızraksı. Petaller darca mızraksı. Mahmuz silindirik. Meyve kapsül. Ülkemizde oldukça geniş bir yayııış alanına sahip olan bu tür, (nisan-) mayıs-temmuz aylarında çiçeklenir. Yetişme ortamı olarak ise 50-2300 m’ler arasındaki karışık ormanları, makilikleri, kalkerli ve şistli toprakları tercih eder. ÇBFCB.

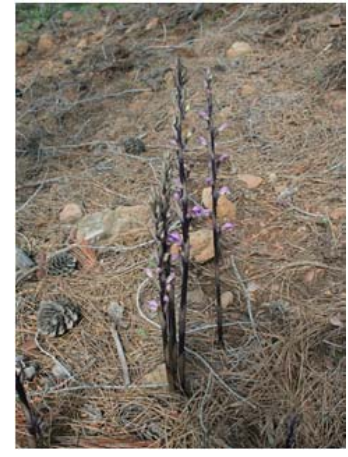

Fig. 52a. Limodorum abortivum var. abortivum

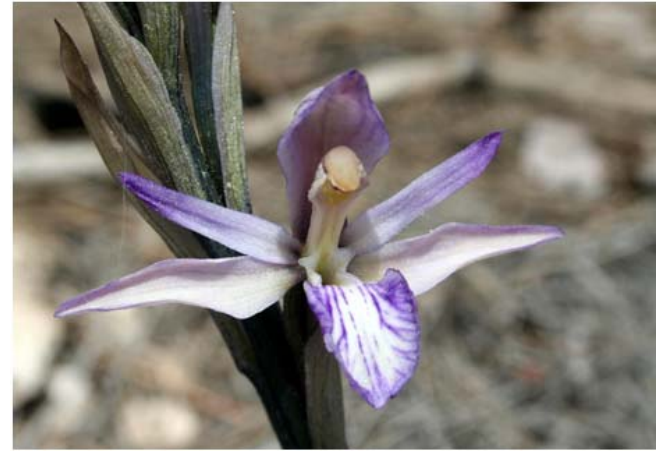

Fig. 52b. Limodorum abortivum var. abortivum Çiçeğinin Yakın Görünüşü

Ophrys phaseliana D. Rückbr. \& U. Rückbr. (faselis salebi) (Türkiye endemiği) (Fig. 53)

15-40 cm boyunda, toprakaltı yumrulu çok yıllık bitkiler. Çiçek durumu seyrek 1-5 çiçekli; çiçekler geniş. Sepaller açık yeşilden yeşile kadar değişen renklerde, dikdörtgenimsi-yumurtamsıdan eliptike kadar değişir. Petaller kaşıksı, uç kısımda dişli, yeşilden sarımsı yeşile kadar değişen renklerde. Labellum 3 loplu, sarımsı-kahverengi, kahverengi tüylü, sarımsı kenarlı; spekulum soluk mavi-gri kenarlı, mavimsi-kırmızımsı benekli. Ülkemize özgü olan bu tür, Muğla ve Antalya illerinde yayılış göstermektedir. Nisan ve mayıs aylarında çiçeklenmekte olup 400 m’ye kadar olan çam ormanı açıklıklarında, frigana'da, çalııklarda, yol kenarlarında ve kalkerli topraklarda yetişmektedir. Akd. El.

Orchis anatolica Boiss. (dildamak) (Fig. 54 a-b)

$40 \mathrm{~cm}$ 'ye kadar boylanabilen yumrulu çok yıllık bitkiler. Yapraklar tabanda 2-4 adet. Çiçekler geniş, gül renkli-mor, nadiren beyaz renkli, mor benekli, sepaller yumurtamsı-küt uçlu; labellum yumurtamsı, 3 loplu. Mahmuz narin yapılı, ovaryumdan uzun. Ülke-

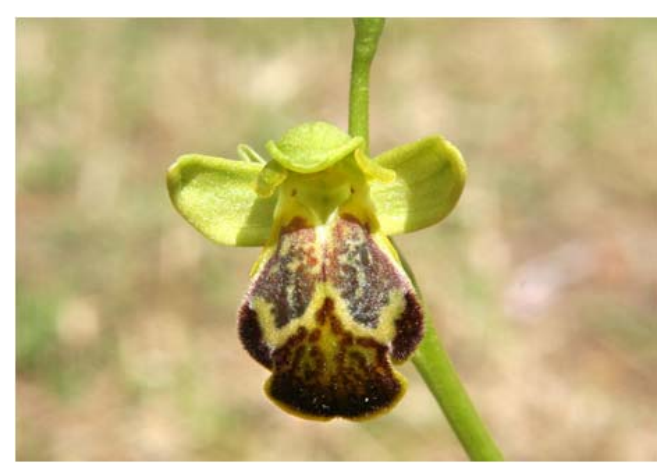

Fig. 53. Ophrys phaseliana mizde geniş bir yayılış alanına sahip olan bu dildamak, mart-mayıs aylarında çiçeklenir. Yetişme ortamı olarak deniz seviyesinden 1650 m'ye kadar olan yüksekliklerdeki makilikleri, çalııkları ve çam ormanlarını tercih eder. Akd. El. 


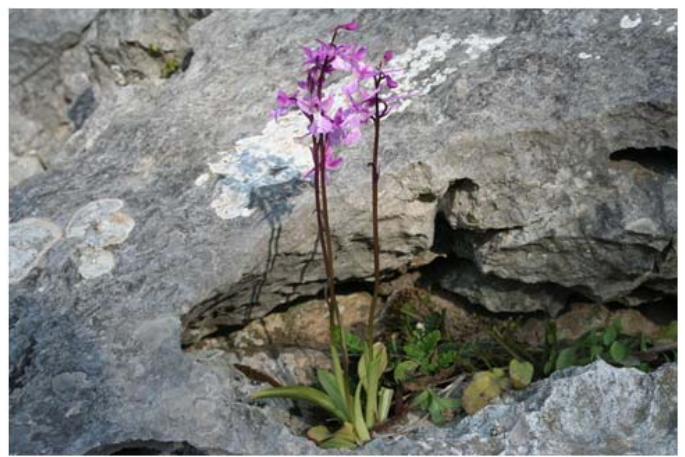

Fig. 54a. Orchis anatolica

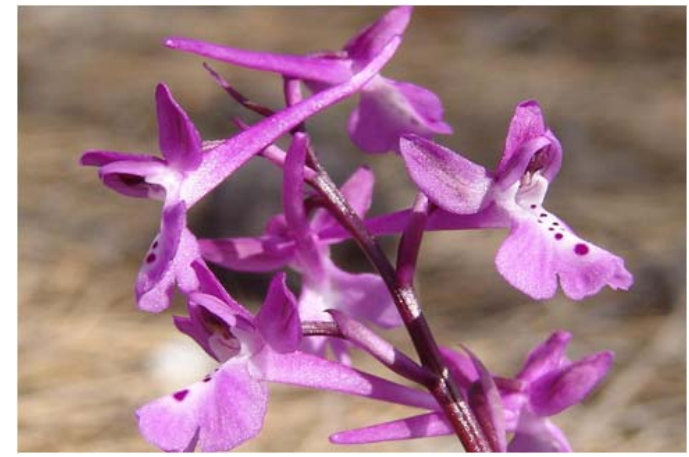

Fig. 54b. Orchis anatolica Çiçeklerinin Yakın Görünüşü

\section{Orchis coriophora L. subsp. coriophora (prinççiçeği)}

20-60 cm boyunda, yumrulu çok yıllık bitkiler. Yapraklar tabanda 4-10 adet, hemen hemen dik, şeritsi-mızraksı. Başak çiçek durumu silindirik. Çiçekler küçük, koyu mor, kahverengi-kırmızı veya yeşilimsi-kırmızı. Labellum yumurtamsı, 6-10 mm, 3 loplu, kırmızımsı-yeşil, morumsu papillalı ve benekli. Mahmuz konik ve belirsiz şekilde kıvrık.Ülkemizde oldukça geniş bir yayılış alanına sahip olan bu alt tür, nisan-haziran aylarında çiçeklenir ve 20-1930 m’ler arasındaki nemli çayırlarda, nehir kenarlarında, kuru kumlu yerlerde ve orman açıklıklarında yetişir. ÇBFCB.

\section{Orchis sancta L. (püren salebi)}

20-60 cm boyunda, yumrulu çok yıllık bitkiler. Yapraklar tabanda 6-12 adet, şeritsi. Çiçekler geniş; sepalin kafasının uç kısmı serbest ve uzamış. Labellum düz, yaklaşık $15 \mathrm{~mm}$ boyunda, pembeden soluk kırmızıya kadar değişen renklerde, beneksiz, çıplak; orta lop dilsi, yan loplar eşkenar dörtgenimsi, 3-4 testere dişli. Mahmuz uç kısımda kıvrık. 450 m yüksekliğe kadar olan kalkerli topraklar üzerindeki güneşli çimenlik alanlarda yetişen bu tür, nisan-haziran ayında çiçeklenir. Akd. El.

\section{Spiranthes spiralis (L.) Chevall (inci salebi)}

20-35 cm boyunda çok yıllık otsu bitkiler. Yapraklar 4-6 tane, yumurtamsı. Gövde brakte benzeri yapraklı. Kedicik çiçek durumu yoğun ve spiral şeklinde, çok çiçekli. Çiçekler beyaz renkli. Ağustos-kasım aylarında çiçeklenen bu tür, yetişme ortamı olarak deniz seviyesinden 500 m'ye kadar olan yüksekliklerdeki çimenlikleri ve çam açıkıklarını tercih eder. Akd. El.

\section{Familya: Poaceae (Buğdaygiller)}

\section{Aegilops biuncialis Vis. (ikikılçık)}

15-30 cm boyunda tek yıllık otsu bitkiler. Üst yapraklar şeritsi-mızraksı. Başak çiçek durumu 1.5$2 \mathrm{~cm}$ boyunda. Kavuz ters yumurtamsı-dikdörtgenimsi veya geniş̧e eliptik, 7-10 mm boyunda. Meyve karyopsis. Ülkemizde oldukça geniş bir yayılış alanına sahip olan bu tür, mayıs-haziran aylarında çiçeklenir. Yetişme ortamı olarak ise deniz seviyesinden 1200 m'ye kadar olan yüksekliklerdeki karaçam ve meşe orman açıklıklarını, stebi, tarla kenarlarını ve üzüm bağlarını tercih eder. ÇBFCB. 
Arundo donax L. (kargı)

Sağlam yapılı, sürünücü rizomlara sahip, 5 m’ye kadar boylanabilen çok yıllık bitkiler. Yapraklar ayası şeritsi, düz, 60 cm'ye kadar çıkar. Salkım çiçek durumu en fazla $70 \mathrm{~cm}$ boyunda. Dış kavuz mızraksı, 7$12 \mathrm{~mm}$ boyunda. Karyopsis meyve dikdörtgenimsi. Ülkemizde batı, güney ve kuzeydoğu bölgelerinde yetişen bu tür, ekim ayında çiçeklenmekte olup, 250 m'ye kadar olan yüksekliklerdeki su kenarlarında ve bataklık alanlarda yayılış göstermektedir. ÇBFCB.

\section{Briza maxima L. (kuşyüreği) (Fig. 55)}

$60 \mathrm{~cm}$ 'ye kadar boylanabilen tek yıllık otsu bitkiler. Gövde yaprakları seyrek ve çıplak. Başakçıklar 1-7

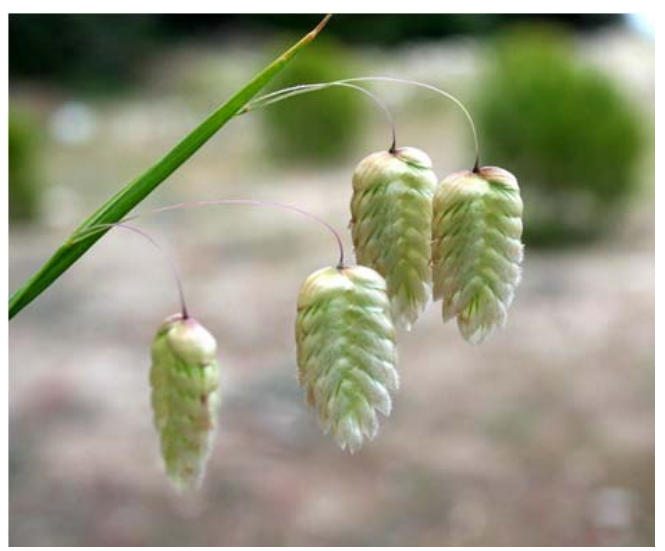

Fig. 55. Briza maxima tane, yumurtamsı. Kavuzlar yatay, geniş̧̧e dairesel-böbreksi. Dış kavuz genişçe kalpsi. Karyopsis meyve genişçe yumurtamsıdan elipsoide kadar değişir. Nisan ve mayıs ayında çiçeklenen bu tür, 320 m'ye kadar olan yüksekliklerdeki, kızılçam açıklıklarında, firigana'da, kireç taşlı kayalık yamaçlarda, kulu alanlarda ve nemli yerlerde yetişir. ÇBFCB.

\section{Hordeum murinum L. subsp. murinum (pisipisiotu)}

10-45 cm boyunda, tek veya seyrek kümeli gövdeye sahip tek yıllık otsu bitkiler. Yapraklar düz. Başak çiçek durumu, dikdörtgenimsi, 4-10 cm boyunda. İ̧̧ kavuz darca mızraksı. İlk kez Yunanistan'dan toplanarak bilim dünyasına tanıtılan bu bitki, mayıs-temmuz aylarında çiçeklenir. Yetişme ortamı olarak ise 900 m'ye kadar olan yüksekliklerdeki stebi, nehir yataklarını, göl kenarlarını, tarlaları ve yol kenarlarını tercih eder. Akd. El.

\section{Lagurus ovatus L. (tavşankuyruğu)}

Dik veya eğik yükselişli, 60 cm'ye kadar boylanabilen tek yıllık otsu bitkiler. Yaprak ayası şeritsimızraksı. Çiçek durumu oldukça yoğun, yumurtamsı-dikdörtgenimsiden yarı küresele kadar değişir. Kavuz darca dikdörtgenimsi. Karyopsis meyve eliptik-dikdörtgenimsi. Deniz kenarındaki kumullarda yetişen bu tür, nisan-haziran aylarında çiçeklenir. Akd. El.

\section{Phragmites australis (Cav.) Trin. ex Steudel (kamış)}

3 m'ye kadar boylanabilen, genellikle basit gövdeli, rizomlu çok yıllık bitkiler. Yaprak ayası düz, şeritsi. Çiçek durumu geniş bir bileşik salkım. Başakçıklar 2-6 çiçekli. Dış kavuz darca mızraksı. Karyopsis meyve dikdörtgenimsi. Ülkemizde geniş bir yayılış alanına sahip olan bu tür, Arundo donax (Kargı)'a çok benzer. Eylül-kasım aylarında çiçeklenen bu tür, 2400 m’ye kadar olan yüksekliklerdeki göllerde, nehirlerde, bataklıklarda, deniz kenarlarında ve kanallarda yetişir. Avr.-Sib.El.

\section{Familya: Smilacaceae (Dikenucugiller)}

Smilax aspera L. (gıcırdikeni) (Fig. 56a-b)

Tırmanıcı, alt kısımda dikenli çalılar. Yapraklar kalpsi-üçgensiden mızraksıya kadar değişen şekillerde, taban kısmında zıpkınsı-oksu.

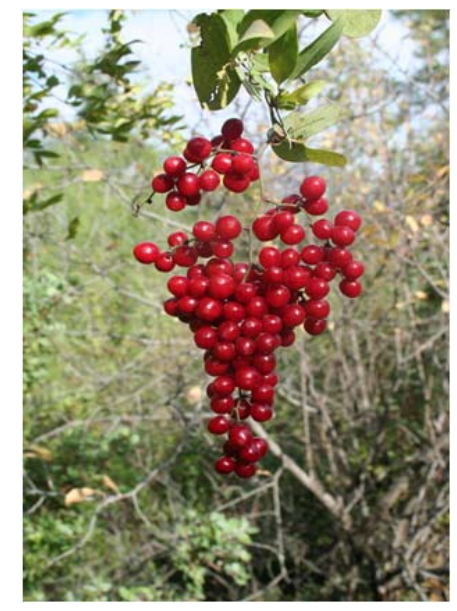

Fig. 56a. Smilax aspera 
Çiçekler sapsız şemsiyelerde; segmentler sarımsıkrem renkli Üzümsü meyveler kırmızı veya siyah renkli. Nisan-haziran aylarında çiçeklenen bu tırmanıcı bitki, yetişme ortamı olarak 50-700 m'ler arasındaki makilikleri, plaj kenarlarını ve kireç taşı kayalıklarını tercih eder. ÇBFCB.

\section{Familya: Xanthorrhoeaceae (Çirişgiller)}

Asphodeline brevicaulis (Bertol.) J. Gay ex Baker subsp. brevicaulis (çirişine) (Fig. 57)

Çok yıllık otsu bitkiler. Gövde eğik tırmanışlı veya dik, 8-70 cm boyunda. Yapraklar çok sayıda, şeritsi. Periyant segmentleri sarı renkli. Kapsül meyve küresel. Nisan-haziran aylarında çiçeklenen bu bitki, yetişme ortamı olarak deniz seviyesinden 1300 m'ye kadar olan yüksekliklerdeki kayalık ve taşı yamaçları, makilikleri çam ormanı ve açıkıklarını tercih eder. Akd. El.

\section{Asphodelus aestivus Brot. (zehirli çiriş otu)}

Dik gövdeli, 2 m'ye kadar boylanabilen çok yıllık bitkiler. Yapraklar şeritsi. Çiçek durumu dallı. Periyant segmentleri beyaz renkli. Kapsül meyve ters yumurtamsı, 5-7 mm. Yetişme ortamı olarak deniz

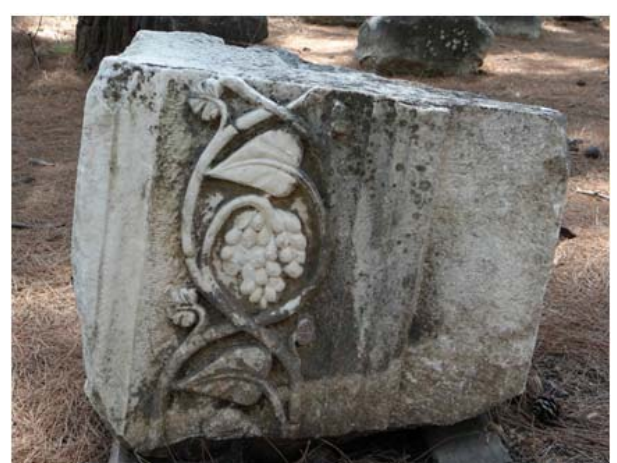

Fig. 56b. Taş Kabartmalarda Smilax aspera'nın Görünüşü

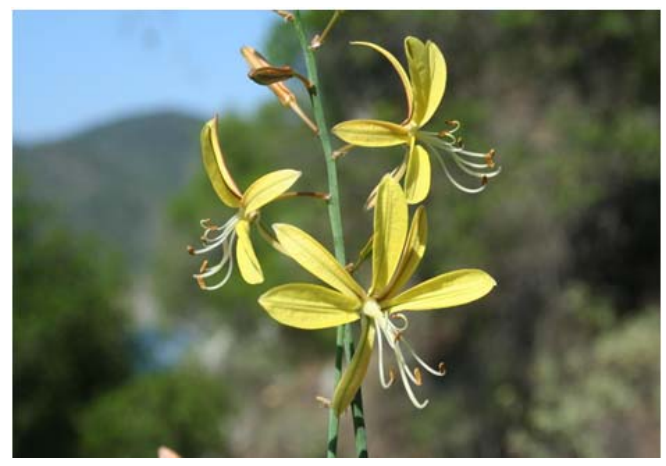

Fig. 57. Asphodeline brevicaulis subsp. brevicaulis seviyesinden 900 m'ye kadar olan yüksekliklerdeki tarlaları tercih eden bu çiriş otu mart-haziran aylarında çiçeklenir. Akd. El.

\section{Sonuç ve Tartışma}

Phaselis Antik Kenti'nde 2012 yılında başlayıp 5 yıl sürecek olan proje kapsamında, 2012-2013 yıllarında gerçekleştirilen arazi çalışmaları sonunda 57 familya'ya ait 191 cins ve toplam 233 takson tespit edilmiştir. Endemik taksonların sayısı ise 30 (\%12,9)'dur. Teşhis edilen 30 endemik taksonun 10 tanesi Olimpos-Beydağları Milli Parkı endemiği, 10 tanesi Antalya endemiği ve 10 tanesi de Türkiye endemiğidir. Özellikle Olimpos-Beydağları Milli Parkı'na özgü türlerin sayısının yüksekliği dikkati çekmektedir. Bunu alanın dağlar tarafından izole edilmiş olması ve alanda çok sayıda habitatın (Serpantin, kumul, sucul, kayalık vs.) bulunması ile açıklıyabiliriz. íki yılın sonunda alanda tespit edilen 233 taksonu Fitocoğrafik Bölgesi elementlerine göre incelediğimiz zaman, 136 tanesinin Akdeniz Fitocoğrafik Bölgesi elementi, 3 tanesinin Avrupa-Sibirya Fitocoğrafik Bölgesi elementi, 2 tanesinin İran-Turan Fitocoğrafik Bölgesi elementi ve 92 tanesinin ise Çok Bölgeli veya Fitocoğrafik Bölgesi Bilinmeyen olduğu tespit edilmiştir. Görüldüğü üzere alanda Akdeniz Fitocoğrafik Bölgesi elementleri 136 tane ile ilk sırada yer almaktadır. Bu durumu araştırma alanın tümüyle Akdeniz Fitocoğrafik Bölgesi içinde yer alması ile açıklıyabiliriz. Avrupa-Sibirya Fitocoğrafik Bölgesi elementleri ve İran-Turan Fitocoğrafik Bölgesi elementlerinin ise alanda belirgin şekilde az sayıda yer aldığı görülmektedir. Bunun nedenini ise bu iki fitocoğrafik bölgenin karakterlerini yansıtan habitatların alanda sınırlı olması ile açıklayabiliriz. Çalışma alanında takson sayısı açısından en zengin ilk 5 familya ve takson sayıları şu şekildedir; Asteraceae 29, Fabaceae 24, Lamiaceae 22, Brassicaceae 13 ve Apiaceae 9. 


\section{Figür Listesi}

Fig. 1. Dorystoechas hastata (Şalba/Devrenkekiği)

Fig. 2. Trigonella coerulescens subsp. kemerensis (kum çemenotu)

Fig. 3. Glycyrrhiza flavescens subsp. antalyensis (Antalya meyanı)

Fig. 4. Cedrus libani var. libani (katran ağacı, Toros sediri)

Fig. 5. Crithmum maritimum (deniz teresi)

Fig. 6. Eryngium maritimum (kum boğadikeni)

Fig. 7. Aristolochia lycica (kargakavuğu) (Antalya endemiği).

Fig. 8. Anthemis ammophila (kum papatyası) (Antalya endemiği).

Fig. 9. Centaurea aegialophila (kum deligözü)

Fig. 10. Centaurea wagenitzii (adrasan düğmesi) (Olimpos-Beydağları Milli Parkı endemiği)

Fig. 11a. Echinops onopordum (öd dikeni) (Antalya endemiği)

Fig. 11b. Echinops onopordum'un çiçekli kapitulasının yakın görünüşü.

Fig. 12. Inula crithmoides (keşir çorağı)

Fig. 13. Onosma strigosissima (yalı şincarı) (Antalya endemiği)

Fig. 14. Conringia grandiflora (iritelkari) (Antalya endemiği)

Fig. 15. Ricotia carnosula (dişli cavlak) (Türkiye endemiği)

Fig. 16. Campanula lyrata subsp. lyrata (memek)

Fig. 17. Capparis spinosa (kebere)

Fig. 18. Cistus creticus (Girit ladeni)

Fig. 19. Erica sicula subsp. libanotica (yılgun çalısı)

Fig. 20. Colutea melanocalyx subsp. melanocalyx (kara patlangaç) (Türkiye endemiği)

Fig. 21a. Glycyrrhiza asymmetrica (Türk meyanı) (Antalya endemiği)

Fig. 21b. Glycyrrhiza asymmetrica'nın çiçeklerinin yakın görünüşü

Fig. 22. Lathyrus belinensis (belen burçağı) (Olimpos-Beydağları Milli Parkı endemiği)

Fig. 23. Lathyrus phaselitanus (Faselis burçă̆ı) (Olimpos-Beydağları Milli Parkı endemiği)

Fig. 24a. Spartium junceum (katırtırnağı)

Fig. 24b. Spartium junceum çiçeklerinin yakın görünüşü

Fig. 25. Quercus infectoria subsp. veneris (zindiyen)

Fig. 26. Clinopodium pamphylicum subsp. davisii (kemer fesleğeni) (Olimpos-Beydağları Milli Parkı endemiği)

Fig. 27a. Lavandula stoechas subsp. stoechas (karabaş)

Fig. 27b. Lavandula stoechas subsp. stoechas çiçeklerinin yakın görünüşü

Fig. 28. Origanum onites (bilyalı kekik)

Fig. 29. Phlomis chimerae (türkmen çırası) (Olimpos-Beydağları Milli Parkı endemiği)

Fig. 30. Salvia fruticosa (adaçayı)

Fig. 31. Sideritis lycia (kemer çayı) (Olimpos-Beydağları Milli Parkı endemiği)

Fig. 32. Stachys sericantha (dikenli çay) (Olimpos-Beydağları Milli Parkı endemiği)

Fig. 33. Myrtus communis subsp. communis (mersin)

Fig. 34. Glaucium flavum (gündürmelâlesi)

Fig. 35. Cymbalaria microcalyx (hoş nakkaşotu)

Fig. 36. Amygdalus graeca (şeytanbademi)

Fig. 37. Pyrus serikensis (zingit) (Antalya endemiği)

Fig. 38. Plocama calabrica (belumçalısı)

Fig. 39a. Verbascum levanticum (arap sığırkuyruğu) 
Fig. 39b. Verbascum levanticum çiçeklerinin yakın görünüşü

Fig. 40. Mandragora autumnalis (adamotu)

Fig. 41. Galanthus elwesii var. monostictus (kardelen) (Türkiye endemiği)

Fig. 42. Pancratium maritimum (kum zambağı)

Fig. 43. Arisarum vulgare (yılancıkotu)

Fig. 44. Arum dioscoridis var. dioscoridis (tirşik pancarı)

Fig. 45. Drimia maritima (kum örümcekotu)

Fig. 46. Colchicum baytopiorum (güz çiğdemi) (Türkiye endemiği)

Fig. 47. Crocus wattiorum (kaya çiğdemi) (Olimpos-Beydağları Milli Parkı endemiği)

Fig. 48. Gynandriris sisyrinchium (keklik çiğdemi)

Fig. 49a. Iris unguicularis subsp. carica var. carica (çalı navruzu) (Türkiye endemiği)

Fig. 49b. Iris unguicularis subsp. carica var. carica çiçeğinin yakın görünüşü

Fig. 50a. Fritillaria acmopetala subsp. acmopetala (duğuk)

Fig. 50b. Fritillaria acmopetala subsp. acmopetala çiçeğinin yakın görünüşü

Fig. 51a. Barlia robertiana (patpatanak)

Fig. 51b. Barlia robertiana çiçeklerinin yakın görünüşü

Fig. 52a. Limodorum abortivum var. abortivum (saçuzatan)

Fig. 52b. Limodorum abortivum var. abortivum çiçeğinin yakın görünüşü

Fig. 53. Ophrys phaseliana (faselis salebi) (Olimpos-Beydağları Milli Parkı endemiği)

Fig. 54a. Orchis anatolica (dildamak)

Fig. 54b. Orchis anatolica çiçeklerinin yakın görünüşü

Fig. 55. Briza maxima (kuşyüreği)

Fig. 56a. Smilax aspera (gıcırdikeni)

Fig. 56b. Taş kabartmalarda Smilax aspera'nın görünüşü

Fig. 57. Asphodeline brevicaulis subsp. brevicaulis (çirişine) 


\section{BIBLIYOGRAFYA}

Alçıtepe - Sümbül 2003

Ayaşlıgil 1987

Çinbilgel 2005

Davis 1965 - 1985

Davis et al. 1988

Deniz - Sümbül 2004

Dinç - Sümbül 2001

Dingil 2002

Duman 1998

Ekim 2005

Göktürk 1997

Göktürk 2009

Güner et al. 2000

Güner et al. 2012a

Güner et al. 2012b

Mataracı 2004

Mutlu - Erik 2003

Peşmen - Güner 1976

Peşmen 1980

Pignatti 1982

Sümbül et al. 1998a

Sümbül et al. 1998b

Sümbül et al. 2003

Sümbül et al. 2005

Sümbül et al. 2006
E. Alçıtepe - H. Sümbül, "Contributions to the Flora of Termessos National Park-Antalya (Türkiye)". Bull. Pure. Appl. Sci 22B/1 (2003) 29-46.

Y. Ayaşlıgil, Der Köprülü Kanyon National Park. Seine Vegetation und ihre Beeinflussung durch der Menschen. Weihenstephan 1987.

i. Çinbilgel, Altınbeşik Mağarası Milli Parkının (ibradı-Akseki/Antalya) Flora ve Vejetasyonu. Yayınlanmamış Yüksek Lisans Tezi, Akdeniz Üniversitesi. Antalya 2005.

P. H. Davis, Flora of Turkey and the East Aegean Islands. Vol.: I-IX. Edinburgh 1965 - 1985.

P. H. Davis, R. R. Mill - K. Tan, Flora of Turkey and the East Aegean Islands. Vol.: X. Edinburgh 1988.

i. G. Deniz - H. Sümbül, "Flora of the Elmalı Cedar Research Forest (Antalya/Turkey)". Turkish Journal of Botany 28 (2004) 529-555.

O. D. Dinç - H. Sümbül, "Sarısu-Saklıkent (Antalya) Florası". Ot Sistematik Botanik Dergisi 8/1 (2001) 29-60.

S. Dingil, Bitkilerle Anadolu. İstanbul 2002.

H. Duman, "A New species of Teucrium L. (Labiatae) from SW Anatolia". The Karaca Arboretum Magazine 4/3 (1998) 125-130.

T. Ekim, "Türkiye'nin Biyolojik Zenginlikleri (Bitkiler)". Türkiye Çevre Vakfı Yayınları 170 (2005) 167-193.

R. S. Göktürk - H. Sümbül, "Flora of Antalya City". Turkish Journal of Botany 21 (1997) 341-378.

R. S. Göktürk, "A New Subspecies Trigonella coerulescens (Fabaceae) from Turkey". Annales Botanici Fennici 46 (2009) 62-64.

A. Güner, N. Özhatay, T. Ekim - K. H. C. Başer, Flora of Turkey and the East Aegean Islands. Vol.: XI. Edinburgh 2000.

A. Güner, S. Aslan, T. Ekim, M. Vural - M. T. Babaç, Türkiye Bitkileri Listesi (Damarlı Bitkiler). İstanbul 2012.

A. Güner, B. Akyıldırım, M. F. Alkayış, B. Çıngay, S. S. Kanoğlu, A. M. Özkan - M. Öztekin, "Türkçe Bitki Adları". Eds. A. Güner et al., Türkiye Bitkileri Listesi (Damarlı Bitkiler). İstanbul (2012).

T. Mataracı, Ağaçlar. İstanbul 2004.

B. Mutlu - S. Erik, "Flora of Kızıldağ Mountain (Isparta) and Environs". Turkish Journal of Botany 27 (2003) 463-493.

H. Peşmen - A. Güner, Dedegöl Dağı (Isparta) Florası. TBAG-164 No'lu Proje. Ankara 1976.

H. Peşmen, Olimpos-Beydağları Milli Parkı'nın Florası. TBAG-335 No'lu Proje. Ankara 1980.

S. Pignatti, Flora d'Italia. Vol.: I-III. Roma 1982.

H. Sümbül, R. S. Göktürk - K. Işık, 250 Plants of Belek. Ankara 1998.

H. Sümbül, R. S. Göktürk, K. Işık - H. Şağban, 20 Endemic Plants of Belek. Ankara 1998.

H. Sümbül, Ö. Tufan, O. D. Düşen - R. S. Göktürk, "A New Taxon of Glycyrrhiza L. (Fabaceae) from Southwest Anatolia". Israel Journal of Plant Science 51 (2003) 71-74.

H. Sümbül, M. Öz, A. Erdoğan, M. Gökoğlu - R. S. Göktürk et al., Türkiye'nin Doğa Rehberi. İstanbul 2005.

H. Sümbül, R. S. Göktürk, O. D. Düşen, I. G. Deniz - H. Uğurluay, Pflanzenführer Der Turkei. İstanbul 2006. 
Tekin 2005

Tutin et al. 1964-1980

Yaltırık 1984
E. Tekin, Türkiye’nin En Güzel Yaban Çiçekleri. İstanbul 2005.

G. T. Tutin, V. H. Heywood, N. A. Burges, D. M. Moore, D. H. Valentine, S. M. Walters - D. A. Webb, Flora Europaea. Vol.: I-V. Cambridge - London 1964 - 1980.

F. Yaltırık, Türkiye Meşelerinin Teşhis Kılavuzu. İstanbul 1984. 